Ítalo Rocha Viana

\title{
VOZES DO DOCUMENTÁRIO NOS ANOS 80: \\ O choque geracional entre distintas representações do real na transição política da década de 80 no Brasil
}

Dissertação de Mestrado

Dissertação apresentada ao Programa de PósGraduação em Comunicação da PUC-Rio como requisito parcial para obtenção do grau de Mestre em Comunicação.

Orientadora: Prof ${ }^{\mathrm{a}}$. Andréa França Martins 
Ítalo Rocha Viana

\section{“VOZES DO DOCUMENTÁRIO NOS ANOS 80: \\ O choque geracional entre distintas representações do real na transição política da década de 80 no Brasil"}

Dissertação apresentada ao Programa de PósGraduação em Comunicação da PUC-Rio como requisito parcial para obtenção do grau de Mestre em Comunicação. Aprovada pela Comissão Examinadora abaixo assinada.

Profa . Andréa França Martins

Orientadora

Departamento de Comunicação Social - PUC-Rio

Profa. Karla Holanda de Araújo

UFF

Profa. Patricia Furtado Mendes Machado

PUC-Rio

Prof. Augusto César Pinheiro da Silva Vice-Decano Setorial de Pós-Graduação CCS

Rio de Janeiro, 25 de Junho de 2018 
Todos os direitos reservados. É proibida a reprodução total ou parcial do trabalho sem autorização do autor, da orientadora e da universidade.

\section{Ítalo Rocha Viana}

Graduou-se em História pela UFRJ em 2015. Atuação profissional voltada para a área do Documentário, com ênfase na parte de Montagem. Participou de congressos e seminários nas áreas de Cinema e História.

Ficha Catalográfica

Viana, Ítalo Rocha

Vozes do documentário nos anos 80: o choque geracional entre distintas representações do real na transição política da década de 80 no Brasil / Ítalo Rocha Viana ; orientadora: Andréa França Martins. -2018.

146 f. : il. color. ; $30 \mathrm{~cm}$

Dissertação (mestrado)-Pontifícia Universidade Católica do Rio de Janeiro, Departamento de Comunicação Social, 2018.

Inclui bibliografia

1. Comunicação Social - Teses. 2. Documentário. 3. Discurso de sobriedade. 4. Década de 80. 5. Gerações. 6. Vídeo. I. Martins, Andréa França. II. Pontifícia Universidade Católica do Rio de Janeiro. Departamento de Comunicação Social. III. Título. 
A meus avós, Kia e Walter (in memorian) e à Débora, minha mãe, pessoas especiais que me formaram na vida e acompanham meus passos desde sempre. 


\section{Agradecimentos}

Aos meus familiares, tão importantes em minha formação e desenvolvimento.

À Ana, amor que floresceu nesses anos. Foi a base no momento mais difícil, tornando-o leve e doce.

Aos companheiros do Cineclube Estrela da Manhã, por nossas inúmeras exibições de filmes, conversas e cervejas.

Aos amigos que, sem a sua presença, este trabalho não teria sido feito: Miguel, Marília, Maldito, Maíra, Nina, Thaís.

Ao meu mestre de capoeira Tadeu Navalha e ao meu grupo CPCAC, pela troca de axé, energia vital para seguir lutando e mandingando em todos os caminhos da vida.

Aos queridos amigos da Modo Operante, pelo apoio e aprendizado.

À minha orientadora Andréa França, pelos conselhos e parceria para que este trabalho resultasse o melhor possível.

Às professoras Patricia Machado e Karla Holanda, pelos importantes comentários em minha banca de defesa.

À professora Vera Lúcia de Figueiredo, pelas instigantes aulas recheadas de "lutas de classes".

À PUC-Rio, pelo apoio e infraestrutura oferecidos. Em especial, à querida Marise Lira, secretária do Programa de Pós-Graduação em Comunicação Social, pela imensa ajuda e carinho ao longo do meu período no Mestrado.

À CAPES, pela bolsa que possibilitou a realização dessa pesquisa. 


\section{Resumo}

Viana, Ítalo Rocha; Martins, Andréa França. Vozes do documentário nos anos 80: $O$ choque geracional entre distintas representações do real na transição política da década de 80 no Brasil. Rio de Janeiro, 2018. 146 p. Dissertação de Mestrado - Departamento de Comunicação Social, Pontifícia Universidade Católica do Rio de Janeiro.

A partir das considerações de Bill Nichols sobre a histórica relação entre o documentário e os discursos de sobriedade, e as de Jean-Louis Comolli sobre a capacidade do documentário de estar aberto à alteridade do real, que o perturba e o convoca, este trabalho investiga representações do real durante a década de 1980 no Brasil, momento decisivo da chamada "transição política" pós-ditadura militar. Para tal, analisa os filmes Terra para Rose (1987, Tetê Moraes), Linha de Montagem (1981, Renato Tapajós), Céu Aberto (1985, João Batista de Andrade), Que bom te ver viva (1989, Lúcia Murat), Cabra marcado para morrer (1984, Eduardo Coutinho), Jânio a 24 quadros (1981, Luiz Alberto Pereira), Mato Eles? (1982, Sérgio Bianchi), e a série de quatro episódios (produzida para a TV Manchete), Japão: uma viagem no tempo (1986, João Moreira Salles). A hipótese apresentada é que esse conjunto de filmes expressam, em sua diversidade, o choque geracional que os anos 80 trazem ao Brasil, seja pela entrada do vídeo como nova forma de linguagem, seja pelo desgaste dos discursos de sobriedade, seja pelo desgaste do pensamento sobre o Brasil.

\section{Palavras-Chave}

Documentário; discurso de sobriedade; década de 80; gerações; vídeo. 


\section{Abstract}

Viana, Ítalo Rocha; Martins, Andréa França (Advisor). Voices of the documentary in the 80's: the generational shock between different representations of real in the political transition of the 1980's in Brazil. Rio de Janeiro, 2018. 146 p. Dissertação de Mestrado Departamento de Comunicação Social, Pontifícia Universidade Católica do Rio de Janeiro.

This dissertation starts with the Bill Nichols's considerations about the historical relationship between documentary and the discourses of sobriety, and also Jean-Louis Comolli thoughts on the documentary's abilities of being open to the otherness of the real, which disturbs it and convokes it, this paper investigates representations of the real during the 1980's in Brazil, a decisive moment of the so called "political transition" that took place after the end of the militar dictatorship. To do so, it analyzes the films Terra para Rose (1987, Tetê Moraes), Linha de Montagem (1981, Renato Tapajós), Céu Aberto(1985, João Batista de Andrade), Que bom te ver viva (1989, Lucia Murat), Cabra marcado para morrer (1984, Eduardo Coutinho), Jânio a 24 quadros (1981, Luiz Alberto Pereira), Mato Eles? (1982, Sérgio Bianchi) and the four episodes series (made by TV Manchete), Japão: uma viagem no tempo (1986, João Moreira Salles). The hypothesis presented is that these films express, in their diversities, the generational shock that the 80 's bring to Brazil, whether by the introduction of video as new form of language, whether by the wear of the discourses of sobriety, whether by the wear of the thoughts about Brazil.

\section{Keywords}

Documentary; discourse of sobriety; 80's; generations; video. 


\section{Sumário}

Introdução

1. O discurso de sobriedade na década de $80 \quad 29$

1.1. Os conflitos sociais filmados $\quad 29$

1.2. Terra para Rose: a sobriedade na voz feminina 32

1.3. Linha de Montagem: "milhares de operários, um só homem" 47

1.4. Céu Aberto: o mito e o "povo doente" 63

2. O momento reflexivo 78

2.1 Os diretores em cena $\quad 78$

2.2 Que bom te ver viva: intervenção contra o silêncio 79

2.30 desdobramento do real: sobre Cabra marcado para morrer $\quad 90$

3. O ataque à sobriedade em dois documentários dos anos 80

3.1 A postura antiilusionista $\quad 104$

3.2 Jânio a 24 Quadros: O Brasil é uma chanchada 106

3.3 Mato eles?: Quem mata? $\quad 115$

4. O vídeo anuncia os novos tempos $\quad 125$

4.1. Uma geração olha o mundo 125

4.2. Japão: uma viagem no tempo: o presente na superfície 127

$\begin{array}{ll}\text { Conclusão } & 138\end{array}$

Referências Bibliográficas $\quad 142$

$\begin{array}{ll}\text { Filmografia } & 146\end{array}$ 


\section{Lista de figuras}

Figura 1 - Rose, a heroína sem-terra. 32

Figura 2 - Estátua A Justiça. $\quad 35$

Figura 3 - A batalha pela memória. 37

Figura 4 - O conflito na montagem. $\quad 40$

Figura 5 - A retórica política e a desilusão com a Constituição. 44

Figura 6 - Sem-terra denunciam a repressão. 46

Figura 7 - O trabalhador e a realização de seu trabalho. 52

Figura 8 - Equipe de filmagem em cena. $\quad 54$

Figura 9 - Policial impede a filmagem do conflito. 54

Figura 10 - "milhares de operários, um só homem”. 57

Figura 11 - Fissuras na representação: operários colocam suas vozes 58

Figura 12 - Lula é aclamado pelos metalúrgicos. 60

Figura 13 - O nascimento do PT. 62

Figura 14 - A sequência de abertura de Céu Aberto. 65

Figura 15 - Tancredo Neves como um inerente conciliador. 67

Figura 16 - O povo desesperado, a mídia desorientada. 68

Figura 17 - Glória e Drama de um Povo (1956, Alfredo Palácios). 70

Figura 18 - O transe coletivo em Céu Aberto. 71

Figura 19 - O desespero para adentrar o Palácio da Liberdade (MG). 72

Figura 20 - A posse de Sarney filmada por trás. 75

Figura 21 - Irene Ravache se dirige ao espectador 82

Figura 22 - O Grande Roubo de Trem (1903, Edwin Porter). 83

Figura 23 - O relato emocionado de Regina Toscano. 84

Figura 24 - A superação das personagens de Que bom te ver viva. $\quad 88$ 
Figura 25 - Os arquivos reconstróem o passado. 92

Figura 26 - Eduardo Coutinho e a equipe de filmagem em cena. $\quad 95$

Figura 27 - Momento de interrupção e hesitação. 97

Figura 28 - A ausência de vestígios de João Pedro Teixeira. 98

Figura 29 - A única fotografia de João Pedro Teixeira. 98

Figura 30 - Passado e presente em Cabra marcado parar morrer. $\quad 100$

Figura 31 - O farsesco em Jânio a 24 Quadros. 108

Figura 32 - Encenação em Jânio a 24 Quadros. 109

Figura 33 - A sequência sobre a eleição de Figueiredo. 112

Figura 34 - Os arquivos dessacralizados em Jânio a 24 Quadros. 113

Figura 35 - Sequência de abertura de Mato eles?. 117

Figura 36 - O último Xetá. 119

Figura 37 - As questões de múltipla escolha em Mato eles?. 121

Figura 38 - Imagem congelada de um japonês tocando sua flauta. $\quad 129$

Figura 40 - Trânsito entre-imagens. 130

Figura 41 - O fluxo de imagens heterogêneas. 131 
Todo o presente é determinado por aquelas imagens que lhe são sincrônicas; Cada agora é o agora de uma determinada cognoscibilidade. Nele, a verdade está carregada de tempo até o ponto de explodir.

Walter Benjamin 


\section{Introdução}

Estabelecer periodizações históricas é sempre um ato complexo, dado que invariavelmente optamos por certos marcos em detrimento de outros. Muitas vezes, a análise corre o risco de homogeneizar a história ao ignorar as múltiplas temporalidades inscritas em determinado período. Entretanto, é precisamente o gesto teórico de buscar a unidade na diferença que pode oferecer uma análise qualitativa, atentando para pontos de contato e afastamento, o contexto de modo mais amplo, e os caminhos que os mais variados grupos e indivíduos encontraram para lidar com os constrangimentos de seu tempo.

Em sua clássica elaboração sobre as temporalidades históricas, Fernand Braudel definiu o presente como uma condensação de outros tempos: “[...] cada 'atualidade' reúne movimentos de origem e de ritmo diferentes: o tempo de hoje data simultaneamente de ontem, de anteontem e de antanho" ${ }^{1}$. Desse modo, Braudel propôs metodologicamente a compartimentação do tempo por durações variadas e convergentes: um tempo longo (o tempo das estruturas, as longuíssimas transformações); um tempo médio (o tempo das conjunturas); e um tempo imediato (o tempo dos acontecimentos, o momento parcial).

Essas três dimensões temporais se combinariam no presente, na atualidade que lança questionamentos ao passado, interrogando, sempre, sobre o seu próprio tempo. Partindo desses pressupostos, o saber histórico se caracteriza como um trabalho de construção do objeto que nunca está dado previamente, mas que se forja no ato de "decompor o tempo passado e eleger as suas realidades cronológicas, segundo preferências e exclusões mais ou menos conscientes"2.

Especificamente em torno do meu objeto, procuro compreender distintas posturas teóricas e cinematográficas do cinema-documentário em um período crucial na história brasileira, a década de 80 , a chamada transição à democracia, momento no qual as incertezas permeavam o cenário político e novos agentes surgiam das transformações empreendidas nos anos anteriores.

Para tal, analiso os filmes Terra para Rose (1987, Tetê Moraes), Linha de Montagem (1981, Renato Tapajós), Céu Aberto (1985, João Batista de Andrade), Que bom te ver viva! (1989, Lúcia Murat), Cabra marcado para morrer (1984,

\footnotetext{
${ }^{1}$ BRAUDEL, 1976, p. 29.

2 Ibidem, p. 11.
} 
Eduardo Coutinho), Mato eles? (1982, Sergio Bianchi), Jânio a 24 Quadros (1981, Luiz Alberto Pereira), e a série documental de quatro episódios Japão, uma Viagem no Tempo (1985), dirigida por Walter Salles.

Por um lado, podemos perceber a busca em escapar ao modelo clássico documental através do tom auto-reflexivo de Cabra marcado para morrer, a quebra da quarta parede em Que bom te ver viva!, ou a própria desconstrução do discurso sóbrio empreendida em Mato eles?. Por outro, há a permanência da impressão de objetividade em documentários como Terra para Rose e Linha de Montagem, nos quais a construção do argumento político prevalece centralmente sobre a mediação do cineasta e a "voz do outro". Já em Japão, uma Viagem no Tempo (1985), caso específico pois se tratou de uma série realizada para a TV, a “questão Brasil" era deixada de lado em prol do mundo cosmopolita que se abria nos idos da década de 80 .

De modo similar ao exercício que me proponho neste trabalho, há no Brasil uma rica tradição crítica de análises fílmicas, seja trabalhando um aspecto narrativo relevante que atravesse diversos filmes, seja investigando o próprio contexto e como realizadores e suas obras expressaram as questões de dado período.

Em uma passagem contundente, Paulo Emílio Salles assinalava que "[...] O cinema norte-americano, o japonês e, em geral, o europeu nunca foram subdesenvolvidos, ao passo que o hindu, o árabe ou o brasileiro nunca deixaram de ser. Em cinema o subdesenvolvimento não é uma etapa, um estágio, mas um estado"3. Este prognóstico, que deve ser mantido ainda que a nível espectral, é um convite a refletir que a descontinuidade reiteradamente propalada em torno do cinema brasileiro inscreve-se tanto nas rupturas entre os períodos mais densos de realizações, como nas análises presenteístas que ignoram toda uma tradição reflexiva sobre a acidentada constituição do cinema nacional ${ }^{4}$.

\footnotetext{
${ }^{3}$ GOMES, 1996, p.85.

${ }^{4}$ Consideração similar é tecida por Eduardo Escorel ao analisar a "política do esquecimento" no Brasil e seus desdobramentos seja no campo cultural seja no campo político: "A cultura oriental parece ter sabido conciliar modernidade e tradição. Tanto na China quanto no Japão, revolução socialista e modernização capitalista preservam o culto às suas respectivas tradições culturais. No caso do Brasil, perverso capitalismo dependente promove modernização com exclusão social em que, ainda mais grave que a já célebre perda da memória nacional, há a verdadeira idolatria do esquecimento. Neste contexto, como pensar em constituir uma nação soberana sem integrar sua história cultural ao projeto de construção do futuro?” (ESCOREL, 2005, p. 39).
} 
Nesse sentido, como bases a guiar minha pesquisa assinalo os seguintes trabalhos: Cineastas e imagens do Povo (1985), de Jean-Claude Bernardet, reunião de ensaios decisivos sobre a articulação da "voz" em documentários brasileiros entre as décadas de 60 e 70; Espelho Partido (2004), de Silvio Da-Rin, análise de largo alcance sobre as transformações do campo documental ao longo da história, detendo-se na virada contemporânea auto-reflexiva; Ver e Poder (2004), de Jean-Louis Comolli, contribuições fundamentais a nível filosófico e metodológico acerca da política das imagens; La representación de la realidad (1997), de Bill Nichols, importantes formulações que atravessam os modos de representação dos documentários e a sua relação com os discursos de sobriedade, aspectos que permeam todo este trabalho. São pesquisas que, a seu modo particular, refletem sobre questões na fronteira entre o cinema e o campo mais amplo da história, atando os nós entre os filmes analisados em perspectiva comparada e o contexto de sua realização ${ }^{5}$.

Também é preciso sublinhar neste trabalho uma ênfase na questão geracional. Embora eu não trabalhe sistematicamente por esse caminho, pois resultaria mais próximo das tipologias sociológicas, é inegável a importância do conceito formulado por Raymond Williams de estrutura de sentimento ${ }^{6}$ - ou de sentido, a depender da tradução -, um profícuo intento de dinamizar teorias engessadas no reflexo entre base e superestrutura ou em apreensões estáticas de conceitos como ideologia. Através da estrutura de sentimento, Raymond Williams buscou apreender o modo contraditório pelo qual os mais variados agentes históricos compartilhavam um conjunto de ideias e práticas na sua própria dinâmica, com pontos em comum e divergentes, mas inseridos em uma mesma experiência.

Metodologicamente, proponho uma distinção entre três gerações de documentaristas a partir da estrutura de sentimento da brasilidade românticorevolucionária formulada por Marcelo Ridenti. Essa estrutura teria perpassado

\footnotetext{
${ }^{5}$ Assinalo ainda os importantes trabalhos: Brasil em Tempo de Cinema (2007), também de JeanClaude Bernardet; Alegorias do Subdesenvolvimento (2012), de Ismail Xavier; A utopia no cinema brasileiro (2006), de Lúcia Nagib; e A Imagem Fria (2003), de Tales A. M. Ab’Sáber.

6 “'Sentimento' é escolhido para ressaltar uma distinção dos conceitos mais formais de 'visão de mundo' ou 'ideologia'. Não que tenhamos apenas de ultrapassar crenças mantidas de uma maneira formal e sistemática, embora tenhamos de levá-las em conta, mas que estamos interessados em significados e valores tal como são vividos e sentidos ativamente, e as relações entre eles e as crenças formais ou sistemáticas são, na prática, variáveis (inclusive historicamente variáveis), em relação a vários aspectos, que vão do assentimento formal com dissentimento privado até a interação mais nuançada entre crenças interpretadas e selecionadas, e experiências vividas e justificadas”. (WILLIAMS, 1979, p. 134).
} 
boa parte da intelectualidade brasileira dos anos 50/60 e seria marcada pela busca de um passado mítico com fins de emancipação das lutas que se travavam no presente ${ }^{7}$. Com o golpe de 64 e a modernização conservadora, os ventos utópicos se afastavam e outras formas de leitura do país vinham à tona. Portanto, a questão geracional não é meramente cronológica, vinculando-se à relação históricopolítica que cada documentarista estabeleceu com seu tempo.

Com efeito, cada geração de documentaristas que se cruzava nos anos 80 teve de encarar um tempo que anunciava mudanças, as quais não passariam incólumes aos caminhos percorridos por seus filmes. Os documentários selecionados neste trabalho trouxeram à tona os principais temas e atores sociais daquele tempo, sendo, em pleno 2018, incrivelmente atuais. Percorrendo-os, deparamo-nos com camponeses e operários em luta; a figura do torturado nos porões da ditadura; personagens proeminentes da história política nacional de posições variadas, como Luis Inácio Lula da Silva, José Sarney e Tancredo Neves; além do ideário de modernidade e integração global (Japão: uma viagem no tempo).

No entanto, mais importante que perceber sobre quem se falava consiste o exercício teórico de compreender como se falava, isto é, como cada filme articulou sua representação do real. O cinema-documentário constitui hoje um campo fecundo e consolidado de experimentação de linguagens no Brasil com um vasto caminho de imagens realizadas. Ao realizar essa pesquisa, deparei-me com a recorrência de alguns filmes e modos de representação que surgiam como marcos fundantes e decisivos do seu desenvolvimento, portanto, imprescindíveis a fim de se compreender o quadro multifacetado dos anos 80 .

Em minha escrita, há um implícito olhar histórico. Ainda que eu procure discutir, de modo mais aprofundado, as questões propriamente de linguagem dos documentários selecionados, a minha formação de historiador, inevitavelmente, leva-me a interrogar as temporalidades que atravessam as obras em si e em perspectiva comparada. Desse modo, por vezes convoco alguns historiadores, como Carlo Ginzburg, e também não historiadores, como o sociólogo Marcelo Ridenti, a fim de melhor compreender determinada conjuntura ou refletir através de suas contribuições teórico-metodológicas.

\footnotetext{
${ }^{7}$ Ver Artistas e intelectuais no Brasil pós-1960 (RIDENTI, 2005).
} 


\section{A tradição de sobriedade no documentário brasileiro}

Na quinta edição do É Tudo Verdade (Festival Internacional de Documentários), realizado no ano 2000, foram eleitos os seguintes filmes como os dez principais documentários nacionais: Aruanda (1959, Linduarte Noronha); Garrincha, alegria do povo (1963, Joaquim Pedro de Andrade); Viramundo (1965, Geraldo Sarno); O país de São Saruê (1971, Vladimir Carvallho); DiGlauber (1977, Glauber Rocha); Mato eles? (1983, Sergio Bianchi); Cabra marcado para morrer (1984, Eduardo Coutinho); Jango (1984, Silvio Tendler); Imagens do inconsciente (1986, Leon Hirszman); e Ilha das flores (1989, Jorge Furtado). Claro que sempre há uma dissonância ou outra, mas em geral é perceptível a hegemonia de determinados estilos em cada época, aspecto que remete aos debates e caminhos de representação que vão se impondo com o transcorrer dos anos.

[...] as estratégias e os estilos utilizados no documentário, assim como os do filme narrativo, mudam. Eles têm uma história. E mudam em grande parte pelas mesmas razões: os modos dominantes do discurso expositivo mudam, assim como a arena do debate ideológico. O realismo confortavelmente aceito por uma geração parece um artifício para a geração seguinte. Novas estratégias precisam ser constantemente elaboradas para representar "as coisas como elas são", e outras para contestar essa representação ${ }^{8}$.

A partir da década de 60, com as transformações advindas de novos equipamentos, técnicas e questionamentos éticos e estéticos proporcionados pelo chamado Cinema Verdade, as tensões entre objetividade e subjetividade marcaram as distintas posturas cinematográficas dos documentaristas brasileiros. Essas transformações podem ser vistas pelo prisma da relação entre o campo documental e os discursos de sobriedade.

Segundo Bill Nichols, ao contrário dos filmes de ficção, o vasto mundo dos documentários se estrutura na articulação de imagens e sons em constante referência aos eventos que experimentamos cultural e cotidianamente. Através de uma inerente indexicalidade com o real, carregam consigo expectativas de legitimidade em suas imagens. Mais precisamente, expectativas de verdade. O autor desenvolve essa questão em dois livros importantes sobre o cinema-

\footnotetext{
${ }^{8}$ NICHOLS, 2005a, p. 47.
} 
documentário - Introdução ao documentário (2005) e, principalmente, La representación de la realidad (1997) - nos quais expõe a noção de discursos de sobriedade. Estes conformariam um tipo de articulação retórica inscrita na produção de saberes que permeiam as vozes científicas, visando dar credibilidade, consistência e autoridade aos enunciados produzidos nos mais variados campos do saber.

O cinema-documentário tem certo parentesco com esses outros sistemas de não ficção que em conjunto constituem o que podemos chamar de discursos de sobriedade. Ciência, economia, política, assuntos exteriores, educação, religião, bem-estar social, todos estes sistemas tomam por certo que possuem poder instrumental; podem e devem alterar o próprio mundo, podem exercer ações e acarretar consequências. Seu discurso tem ar de sobriedade porque raramente é receptivo a personagens, acontecimentos ou mundos inteiros «fictícios» (a menos que sirvam como simulações pragmaticamente úteis do «autêntico»). Os discursos de sobriedade têm um efeito moderador porque consideram sua relação com o real direta, imediata, transparente. Através deles o poder se exerce por si mesmo. Através deles se faz com que ocorram coisas. São veículos de domínio e consciência, poder e conhecimento, desejo e vontade. O documentário, apesar de seu parentesco, nunca foi aceito como igual ${ }^{9}$.

“Apesar de seu parentesco, nunca foi aceito como igual”. Essa consideração final é fundamental para compreender o lugar ocupado pelos documentários. Diferente dos discursos de sobriedade, que geralmente estruturam sua linguagem através de elementos "fixos", principalmente escritos, os documentários manejam o real através de imagens e sons, fabulações, reflexões e sentenciamentos diretos ou indiretos, o que inevitavelmente acentua o caráter subjetivo de sua construção. Ainda que próximo, o cinema-documentário, ao longo da história, não atingiu o posto de objetividade dos dispositivos já consolidados na produção de saberes ou informações, como artigos científicos, livros ou reportagens:

Este nível mais elevado de discurso pragmático e expositivo acerca de temas reais segue em posição de controle. Adapta-se à preocupação pela produção em todas as formas que dominam nossa cultura. A preferência pelo conhecimento não ficcional, não narrativo e instrumental e a ciência «pura e dura» complementa o motor do progresso e o poder produtivo do capitalismo como sistema socioeconômico ${ }^{10}$.

\footnotetext{
${ }^{9}$ NICHOLS, 1997, p. 32 (tradução nossa).

${ }^{10}$ Ibidem, p. 33 (tradução nossa).
} 
Podemos falar, portanto, de uma íntima relação entre o cinema-documentário e os discursos de sobriedade. Porém, é preciso enfatizar, uma relação, e não uma identidade. Sendo assim, os discursos de sobriedade irão impregnar mais ou menos cada obra de acordo com seus postulados e meios de realização.

Os filmes eleitos pelo É Tudo Verdade revelam as décadas de 60, 70 e 80 como momentos de ebulição de formas e debates que os documentaristas brasileiros propuseram em torno das representações do real. Nesse sentido, tem-se Aruanda como marco da estética da fome ${ }^{11}$ que perpassou boa parte do cinema nacional nos anos 60; Viramundo enquanto representante máximo do "modelo sociológico" que se propunha a explicar de modo objetivo e generalizante as contradições do país; a implosão da representação documental e do discurso de sobriedade com Di-Glauber e Mato eles?, chegando ao momento auto-reflexivo com distintos tons entre Cabra marcado para morrer e Ilha das flores.

A importância desses anos é detalhada por Jay Ruby ${ }^{12}$. O autor sinaliza que uma série de questões de caráter ético e epistemológico acerca da interferência da câmera e da equipe que ocuparam os primeiros documentaristas foram atualizadas na década de 60 com o advento de novas tecnologias, a influência das Ciências Sociais e da televisão. Operou-se, assim, uma profunda reflexão em torno da consciência de si no processo de conhecimento com o objeto filmado. O reconhecimento da subjetividade e da intervenção do cineasta elevam-se sobre a crença na impessoalização do discurso clássico.

Foi nesse contexto que aflorou o Cinema Verdade, inaugurando uma nova fase no campo documental. Neste cinema, a não-intervenção passara ao largo de suas implicações éticas e a noção de "verdade" se referia à relação gerada entre o documentarista e o filmado. Ainda hoje, vários de seus princípios seguem norteando as produções atuais: a prevalência da interação, a reflexividade, uma postura ética que consiste em não mascarar os procedimentos enunciativos, o uso da câmera na mão e o recurso decisivo de entrevistas e depoimentos que inscrevem seu próprio estilo.

\footnotetext{
${ }^{11}$ Aruanda foi prontamente abraçado por Glauber Rocha e reconhecido como marco decisivo do moderno cinema brasileiro que se desenvolvia: "Linduarte Noronha e Rucker Vieira entram na imagem viva, na montagem descontínua, no filme incompleto. Aruanda assim inaugura o documentário brasileiro nesta fase de renascimento que atravessamos [...]" (ROCHA, 2003, p. 126-126).

${ }^{12}$ RUBY, 1977.
} 
No Brasil, a tradição do Cinema Verdade se combinou de maneira um tanto complicada a outros modelos documentais ${ }^{13}$. Trato, aqui, da série de filmes que Jean-Claude Bernardet, em seu trabalho clássico Cineastas e imagens do povo, caracterizou como "modelo sociológico". Nos anos 60 e 70, incutidos com a ideia de desalienação do povo junto à função pedagógica e militante do cinema, diversos cineastas se lançaram a explicar as mazelas do país partindo de premissas que antecediam o corpo-a-corpo com a realidade. Nas palavras de Bernardet, esta cinematografia era marcada por "[...] um saber generalizante que não encontra sua origem na experiência, mas no estudo de tipo sociológico [...] ele dissolve o indivíduo na estatística, e diz dos entrevistados coisas que eles não sabem a seu respeito" 14 .

Nessa perspectiva, dirigida por um a priori expresso na "voz do saber" do locutor, uma verdade generalizante foi buscada como forma de denúncia social em importantes filmes do cinema brasileiro como Viramundo (1967, Geraldo Sarno), Maioria Absoluta (1964, Leon Hirszman), Opinião Pública (1967, Arnaldo Jabor), entre outros. Embora articulem o estilo observacional com improvisações, a própria câmera na mão característica do contato imediato com a realidade, além de um longo repertório de entrevistas e depoimentos, esses filmes tenderam a aprisionar o mundo filmado através de um encadeamento na montagem a referendar suas teses. Além do mais, o constante recurso da narração em voz off vinha a dirimir toda possibilidade de dissenso e contradições contidas nas imagens. Desse modo, a realidade era encaixotada como um dado objetivo a ser comprovado pela objetividade da câmera. Paradoxalmente, filmes como Viramundo e Opinião pública, que trataram da alienação em diferentes estratos da sociedade, eram a própria encarnação de uma relação alienada entre cineasta e realidade.

Adentrando os anos 70, Jean-Claude Bernardet observou uma crise gerada por filmes produzidos à margem dos grandes apoios e circuitos institucionais, que vieram a destronar o hegemônico "modelo sociológico":

Sob a influência da evolução política posterior ao golpe militar de 64, dos movimentos sociais que foram abafados ou conseguiram se expressar, do questionamento relativo ao papel

\footnotetext{
${ }^{13}$ Para uma análise mais detalhada, ver Cinema Verdade no Brasil (RAMOS, 2004).

${ }^{14}$ BERNARDET, 1985 , p. 13
} 
dos intelectuais, das diversas revisões por que passaram as esquerdas, do aparecimento das "minorias" que colocaram a questão do outro, da evolução do Cinema Novo e da perda de sua hegemonia ideológica e estética, das preocupações quanto à linguagem cinematográfica, ao realismo e à metalinguagem, este cinema viveu uma crise intensa, profundamente criadora $\mathrm{e}$ vital ${ }^{15}$.

Filmes como Liberdade de imprensa (1967) e Migrantes (1973), ambos de João Batista de Andrade, passaram a operar de modo a intervir no real e registrar os efeitos dessa ação, gerando, assim, novas sínteses e a ampliação da voz do outro que se filmava. Esse deslocamento da alteridade, que Jean-Claude Bernardet denominou "dramaturgia de intervenção", revelava-se uma forma perspicaz de escapar às buscas sóbrias por apreender a realidade objetivamente.

As conturbadas décadas de 60 e 70, portanto, com a afirmação do moderno cinema brasileiro, legaram diversas imagens e experiências que a cinematografia subsequente teve inevitavelmente de lidar. Lúcia Nagib demonstra que mesmo os filmes da chamada "retomada" nos anos 90, a partir de um caminho outro que as denúncias sociais e o vanguardismo estético, prestaram contas a obras fundantes como Deus e o Diabo na Terra do Sol (1964, Glauber Rocha) ${ }^{16}$.

No cinema-documentário não seria diferente. Os filmes que analiso neste trabalho, todos realizados nos anos 80 , revelam um amálgama de experiências cinematográficas, variando entre discursos diretos e militantes, reflexões mais abertas sobre si e o porvir dos eventos filmados, radicais implosões narrativas como forma de escape à sobriedade reinante no documentário nacional, além da própria "fuga" da questão Brasil que pautou os anos anteriores. A década de 80 revela-se, portanto, um momento de extrema relevância política e cultural.

\section{O documentário brasileiro no contexto dos anos 80}

Década perdida para uns, de renascimento para outros, os anos 80 assinalavam, ao mesmo tempo, a decadência do consumismo dos anos anteriores e a retomada das lutas no campo, nas fábricas, nos sindicatos. Florescera uma nova

\footnotetext{
${ }^{15}$ Ibidem, p. 8.

${ }^{16}$ NAGIB, 2006.
} 
esquerda ante o esfacelamento generalizado da luta armada ${ }^{17}$ e a derrota dos ideais nacionais-democráticos defendidos por organizações como o ISEB (Instituto Superior de Estudos Brasileiros) e o PCB (Partido Comunista Brasileiro).

Do ponto de vista econômico, o país vivia uma grave recessão. Na década de 70, a abertura do país ao capital multinacional nos braços dos militares instituiu um padrão de acumulação pautado pelo consumo de automóveis e produtos de "linha branca". Disseminados na publicidade televisiva, conformavam, junto à repressão à esquerda e ao arrocho salarial contra os trabalhadores, a modernização conservadora ${ }^{18}$ de caráter pequeno-burguês posta em prática por aqui. A conta do "milagre econômico" viria na década seguinte, tendo sido comumente chamada de "década perdida" ao delinear a decadência do american way of life por conta do aprofundamento da dívida externa e das desigualdades sociais.

Já no âmbito político, a "transição lenta, gradual e segura" arquitetada por Ernesto Geisel e pelo general Golbery do Couto e Silva vinha sendo articulada pelas principais lideranças do campo político, militar e empresarial. Buscava-se conciliar por cima a fraturada sociedade brasileira a fim de se realizar a abertura democrática sem grandes turbulências. O mais emblemático aspecto dessa grande transação reside na Lei de Anistia de 1979, a qual pôs em pé de igualdade torturadores e torturados pelo Estado brasileiro durante os anos 1961-1979 ${ }^{19}$.

Como de praxe, o campo cultural foi fortemente abalado pela crise que assolou o país. Por conta dos limites deste trabalho, em torno especificamente do

\footnotetext{
${ }^{17}$ Uma importante análise sobre o universo da esquerda nos anos 60/70 e o papel dos artistas nesse campo foi exposta por SCHWARZ (1978). Recentemente, RIDENTI (2010) apresentou importantes trabalhos em torno do que definiu como uma "estrutura de sentimento da brasilidade romântico-revolucionária", investigando centralmente a inserção dos artistas nas lutas políticas do período.

${ }^{18}$ De acordo com o seminal trabalho de DREIFUSS (1981), a ditadura teve como característica última a modernização capitalista do Brasil, orientada pelos ditames do capital multinacional e associado, agrupamento de empresários brasileiros articulados ao capital internacional. Em sua pesquisa, demonstra que o golpe consistiu em uma grande conspiração forjada principalmente no Instituto de Pesquisas e Estudos Sociais (IPES) e no Instituto Brasileiro de Ação Democrática (IBAD), o "complexo IPES/IBAD", e de militares formados na Escola Superior de Guerra (ESG). Portanto, "um movimento de classe, e não um mero golpe militar". Do ponto de vista ideológico, RIDENTI (2005) assinala uma certa descrença com a ideia de modernidade tal qual se manifestou nos anos 70 no Brasil: "[...] afastava-se a proximidade imaginativa da revolução, enquanto a sociedade se modernizava e urbanizava, permitindo constatar que a industrialização e as novas tecnologias não levaram à libertação mas, ao contrário, conviviam bem com uma ditadura".

${ }^{19}$ Sobre o caráter negociado da transição brasileira, ver Contrarrevolução e ditadura: ensaio sobre o processo político brasileiro pós-1964 (LEMOS, 2014). Especificamente em torno da anistia de 1979, ver Anistia e crise política no Brasil (LEMOS, 2002).
} 
cinema-documentário, é preciso ressaltar a gradativa desestruturação da Embrafilme, empresa criada em 1969 e que nos anos 70 abrigou boa parte das realizações de cineastas oriundos, principalmente, do Cinema Novo. A década de 80 anunciava a agoniante "morte" do cinema brasileiro, culminando com a chegada de Collor ao poder em 1990 e o fim da relação entre cinema e Estado que havia se constituído com a Embrafilme.

Por outro lado, a modernização conservadora empreendida durante o período ditatorial engendrou transformações que afirmaram a TV como um elemento central na reprodução do capital e na construção de hegemonia sobre a imagem do Brasil que se buscava ${ }^{20}$. Ante à contraditória situação de repressão política e intentos de abarcar um público maior com suas obras, uma série de intelectuais identificados com a esquerda adentraram o mundo televisivo nos anos 70 . Sublinho o caso de Eduardo Coutinho, cineasta originário do Centro Popular de Cultura (CPC), da União Nacional dos Estudantes (UNE), que fora perseguido em meio às filmagens de Cabra marcado para morrer, filme que se desdobraria em obra decisiva do cinema nacional. Durante a década de 70, Coutinho participou de diversos documentários produzidos para o Globo Repórter, como Seis dias em Ouricuri (1976) e Theodorico, imperador do sertão (1978), assinalando um momento de rico intercâmbio estético entre o mundo do cinema e a televisão. Sua trajetória é bastante reveladora acerca das vicissitudes que envolveram a experimentação de linguagem audiovisual na TV ao longo dos anos. Em suas próprias palavras,

No fim, eu fiz uns cinco ou seis programas inteiros e só. Isso durou até 1979, em 1979 piorou tudo e piorou muito. Em 1981, quando a equipe do programa se mudou para o prédio [da sede da TV Globo], o programa passou a ser feito em vídeo, e trouxeram os repórteres e aí acabou de vez, acabou mesmo. Eu fiquei lá só para terminar o Cabra mesmo, não me preocupava mais com nada, só com o Cabra, não queria mais saber de nada, fazia o que me mandavam e pronto. De 1974 a 1978, mais ou menos, ainda tinha coisa boa sendo feita. Depois, complica tudo. Afrouxa a ditadura militar e começa a do mercado que é

\footnotetext{
${ }^{20}$ Sobre o Globo-Shell e Globo Repórter, Andréa França atenta que “[...] Se o documentário na TV foi usado para arquivar consenso social, é porque ele foi abraçado com os olhos voltados para o futuro, resultado de certas relações de força que detinham o poder e que permitiriam à memória coletiva recuperá-lo mais à frente. O casamento temporário do documentário com a televisão brasileira [...] viria a legitimar uma variedade imensa de assuntos, todos eles tornando-se ou com possibilidade de tornarem-se "verdadeiros assuntos nacionais", isto é, com poder de interferir na arena pública [...]” (FRANÇA, 2012, p.152).
} 
bem pior $^{21}$.

Foi em meio à consolidação da televisão como principal veículo (in)formador do cidadão comum junto à decadência do cinema por conta da crise nacional que, nos anos 80, o vídeo se espalhou e ganhou a adesão de jovens realizadores mais "antenados" com as novas tendências culturais em circulação pelo mundo. Há, nesse momento, uma não declarada disputa estética e política sobre o ser moderno no Brasil, sobre quais interesses irão se afirmar em um país em vias de se democratizar e se abrir para o mundo.

Como aponta Andréa França, é significativo que um bom número de séries documentais produzidas para a TV Manchete tenham abordado outros povos Japão, uma Viagem no Tempo (1985, série de quatro episódios), dirigida por Walter Salles, China, o Império do Centro (1987, série de cinco episódios) e América (1989, série de cinco episódios), dirigidas por João Moreira Salles, African Pop (1989, série de cinco episódios), de Belisário Franca, Xingu - a terra mágica dos índios (1985, série de onze episódios), de Washington Novaes.

O documentário na televisão aberta, sobretudo as séries feitas para a Rede Manchete na segunda metade da década de 1980, irá dialogar com esse novo desejo de internacionalização, de renovação da linguagem documental televisiva, assumindo diferentes perspectivas diante da constatação de que mundo e sujeito "modernos" são contaminados e forjados pela cultura de massa e pela proliferação das imagens ${ }^{22}$.

Não obstante, enquanto o mundo moderno e globalizado era o tema desta nova geração de realizadores que penetrava na televisão pela linguagem do vídeo, a tradição do documentário nacional seguia sua busca pelo povo brasileiro. De modo geral, com o arrefecer do regime nos anos 80 , antigos militantes e figuras destacadas retornavam do exílio, enquanto novos atores sociais surgiam e ganhavam relevância no cenário político nacional. Bem diferente do que os telejornais buscavam passar cotidianamente ${ }^{23}$, os "anos de chumbo" haviam

\footnotetext{
${ }^{21}$ SACRAMENTO, 2008, p. 205.

${ }^{22}$ FRANÇA e REBELLO, 2015, p. 2.

${ }^{23}$ Atuantes na desestabilização do governo de Goulart, as Organizações Globo se mantiveram intimamente associadas ao regime militar, sendo favorecidas constantemente com investimentos financeiros. Em contrapartida, o jornalismo global propagandeava o país e criminalizava os movimentos de resistência, ao ponto de Médici proferir: "Sinto-me feliz, todas as noites, quando ligo a televisão para assistir ao jornal [nacional]. Enquanto as notícias dão conta de greves, agitações, atentados e conflitos em várias partes do mundo, o Brasil marcha em paz, rumo ao
} 
aprofundado as contradições sociais do Brasil e, junto a questões nunca resolvidas na história do país, como a reforma agrária, agregavam-se as mazelas da modernização conservadora com os fluxos migratórios para os centros urbanos e a pauperização da classe trabalhadora sob arrocho salarial.

Nesse momento, alguns cineastas da geração dos anos 60 e 70, a maioria tendo participado de alguma forma dos movimentos sociais e políticos pré-golpe e de combate à ditadura, lançaram-se a reler o país a partir da sua nova configuração histórica. Tomados em conjunto e todos realizados na década de 80 , os documentários Linha de Montagem (1982), Cabra marcado para morrer (1984), Céu aberto (1985), Terra para Rose (1987), Que bom te ver viva (1989), tanto remontam à tradição cinematográfica nacional de investigar questões sociais inscritas na formação do país, quanto empreendem, uns mais, outros menos, um balanço histórico sobre a experiência recente de lutas pela ampliação dos direitos sociais naufragados com o golpe de 64. Não por acaso, são filmes realizados quando os militares já haviam logrado transformar o Estado brasileiro e passavam o poder efetivamente para as mãos dos civis.

Porém, a forma como lidaram com o real foi bastante diferente. Enquanto em Cabra marcado para morrer e Que bom te ver viva estamos em constante presença do diretor ou da diretora, Linha de Montagem, Céu aberto e Terra para Rose, vinculados diretamente a algum projeto político de caráter mais imediato, estão mais próximos da lógica de sobriedade, priorizando o argumento, "a causa", através de uma construção mais "objetiva" do real. Na política do documentário, Cabra marcado para morrer e Que bom te ver viva se distanciam desses outros filmes por aceitarem as ambiguidades da realidade, inscritas no próprio filme, como no caso de Eduardo Coutinho, ou como forma de provocação ao espectador, no caso de Lúcia Murat. São filmes em que a voz de seus personagens podem se exprimir de forma mais íntegra.

Como apontei anteriormente, o aspecto geracional é fundamental para compreender as diferenças de perspectivas acerca das imagens produzidas no país. Esse quadro resulta mais complexo ao verificar uma geração intermediária expressa em documentários como Jânio a 24 quadros (1981), de Luiz Alberto

desenvolvimento. É como se eu tomasse um tranquilizante após um dia de trabalho". (ARÊAS, 2015). 
Pereira, e Mato eles? (1982), de Sergio Bianchi ${ }^{24}$, obras que também abordaram a história do país, porém pela via do "escracho". Quer pela ironia quer pelo humor explícito, pelo sarcasmo generalizado, essa geração pôs em questão o próprio tratamento sóbrio que a tradição documental estabelecera no Brasil. Um depoimento de Luiz Alberto Pereira, sobre Jânio a 24 quadros, é ilustrativo acerca das questões que sua geração trazia:

Quis fazer um filme irreverente, que ilustrasse a atitude da minha geração diante da política. Tenho 31 anos. [...] Minha abordagem do personagem é típica da minha geração. Eu tinha 13 anos em 1964. Ouvia os Beatles como todos os adolescentes. (...) Jânio contrasta com documentários mais sisudos como Os anos JK, de Silvio Tendler, e Getúlio Vargas, de Ana Carolina". ${ }^{25}$

Essas três gerações revelam um profundo imbricamento de temporalidades, confrontando noções como o arcaico e o moderno. Tais questões se acentuam em países periféricos como o Brasil, no qual as transformações tendem a vir de cima para baixo, varrendo para debaixo dos tapetes as reivindicações populares ao forjar uma política do esquecimento sempre marcada pelo porvir, aqui expressa nas ideologias do "Brasil Grande", o "país do futuro".

Ao analisar o caso mexicano, Octavio Paz percebia um descompasso na relação de seu povo com o tempo, fundalmentalmente através de uma exteriorização da experiência por conta do colonialismo e do imperialismo: “[...] o ingresso na modernidade exigia um sacrifício: o nosso. É conhecido o resultado desse sacrifício: ainda não somos modernos, porém desde então estamos a procura de nós mesmos" 26 . De modo similar, a sincronia histórica ${ }^{27}$ parece não combinar

\footnotetext{
${ }^{24}$ Andréa França elenca outras obras que compartilham da mesma desestabilização dos discursos de sobriedade, como O terceiro milênio (1981, de Jorge Bodanzky), e Ilha das Flores (Jorge Furtado, 1989), (FRANÇA, 2015).

25 "Jânio a 24 Quadros vê com câmera irreverente a década de 60", Jornal O Globo, 06/08/1982.

${ }^{26}$ PAZ, 1989, p. 28.

${ }^{27}$ Expressão do pensamento romântico, o modernismo em seus vários momentos no Brasil lidou com os anacronismos inscritos em nossa formação: "No modernismo brasileiro, afirma-se, então, a tendência para valorizar o efeito singular das nossas misturas e anacronismos, marcando-se como positivo aquilo que, entre nós, resistiu à aceleração do tempo e que não necessariamente deveria ser visto como atraso, podendo, ao contrário, ser tomado como resistência a uma modernização pautada pelo ritmo dos negócios, pela mentalidade pragmática e competitiva do norte" (FIGUEIREDO, 2006).
} 
em um país como o Brasil que, em vias de se democratizar, manteve diversas estruturas forjadas pela ditadura ${ }^{28}$.

As temporalidades históricas reverberam de distintas formas pelos filmes deste trabalho: a interrogação sobre o passado e o futuro (Cabra marcado para morrer), a tragédia do passado e a redenção no presente (Que bom te ver viva), a utopia democrática (Céu Aberto), a utopia operária (Linha de Montagem), a catástrofe iminente (Mato Eles?), a farsa iminente (Jânio a 24 Quadros), a necessidade de seguir, apesar de tudo (Terra para Rose), o fim dos referentes históricos e geográficos (Japão, uma viagem no tempo).

Contudo, é preciso ressaltar que esses lugares não são estáticos e uma ruptura de grande intensidade pode ser encontrada no discurso de Elizabeth Teixeira que encerra o Cabra ao afirmar que "a mesma luta está plantada". Esta imagem se congrega ao melancólico desfecho de Céu Aberto, no qual a posse de José Sarney é filmada por trás, ou ainda ao trágico fim de Rose. São imagens que, ao escaparem à celebração do progresso, perturbam as narrativas oficiais e anunciam um tempo de incertezas. Ao analisá-las hoje, adquirem ainda maior potência por conta da permanência dos principais problemas sociais que trouxeram à tona.

Outro aspecto importante para a validação deste estudo consiste na pouca quantidade de pesquisas sobre os filmes que analiso. Obras como Terra para Rose, Céu Aberto, Linha de Montagem, Jânio a 24 Quadros, a meu ver, documentos fílmicos extremamente relevantes sobre a história do cinema nacional, quer a nível de linguagem quer a nível de registro de uma época, ainda hoje são pouquíssimo pesquisados. A exceção é Cabra marcado para morrer, tido por muitos como o maior documentário já realizado no país e objeto de inúmeros trabalhos. Sua escolha se justifica porque, ao longo desta pesquisa, pareceu-me o filme do período que melhor resolve a dialética entre objetividade e subjetividade como forma de representar o real. Por conseguinte, uma obra documental também de largo alcance e das maiores bilheterias do país, Jango (1984, Silvio Tendler), foi por mim preterida porque não atendia a nenhum dos dois pressupostos básicos que me orientaram nesta seleção: (1) ser um documentário pouco estudado; (2) apresentar algum mecanismo de tensionamento sobre a relação do campo documental com os discursos de sobriedade.

\footnotetext{
${ }^{28}$ Sobre as permanências da ditadura, ver $O$ que resta da ditadura (TELES e SAFATLE, 2010).
} 
Além do mais, meu objetivo não consiste em prestar uma análise específica de tais obras tão heterogêneas, mas observá-las dentro das transformações do campo documental de forma abrangente e relacional. Sendo assim, para além de meras representações de uma realidade exterior (o mundo, o país, a sociedade), proponho-me a analisar os filmes em conjunto como um córpus de documentos que devem ser lidos em sua interioridade. Em resumo, este trabalho é uma seleção consciente de determinados filmes e aspectos em relação a outros, sem pretensão de esgotar qualquer obra.

Ao tomar esses filmes em conjunto, percebo dois movimentos. $\mathrm{O}$ primeiro consiste no desgaste da pretensão de objetividade no documentário nacional. Nesse sentido, faço um percorrido que se inicia, no capítulo 1, com os filmes nos quais os discursos de sobriedade estão bastante presentes e fundam a sua relação com o mundo filmado (Terra para Rose, Linha de Montagem, Céu Aberto). Procuro perceber suas principais estratégias formais de persuasão, atentando para o contexto de sua realização (a luta política), e a forma como o "outro" filmado é posto em cena.

Adiante, no capítulo 2, analiso Que bom te ver viva!, e Cabra marcado para morrer, filmes que se tensionam o pensamento de sobriedade no documentário em prol do encontro com o outro marcado pela fabulação e pela imprevisibilidade, colocando-se como um lócus de produção de significados. Embora contenham e produzam asserções sobre o Brasil, o fazem como síntese da ação do diretor/diretora com a realidade filmada. Busco apreender, nesses dois documentários, como expressam o deslocamento da pretensa objetividade documental.

Já no capítulo 3, trato dos filmes Jânio a 24 quadros e Mato eles?. Aqui, já não cabe interrogar sobre impressão de objetividade. São documentários que olham antes para si que para uma realidade exterior. Em outras palavras, a reflexão que esses filmes propõem passa primordialmente pela desmontagem dos cânones documentais. É verdade que a questão-Brasil continua inscrita nesses documentários, porém, diferente dos filmes do capítulo 1, em que a representação ocorre de forma bastante sóbria, e os do capítulo 2, situados na fronteira entre objetividade e subjetividade, Mato eles e Jânio a 24 quadros subvertem o próprio tom do documentário através da ironia e do deboche como formas de desconstrução narrativa. Interessa-me, então, apreender os seus mecanismos 
formais e como incidem sobre a representação da história do país.

O segundo movimento que percebo na década de 80 consiste no desgaste do pensamento sobre o Brasil nas novas gerações de realizadores. É marcante que, enquanto o Globo Repórter, durante os anos 70, tenha tratado exclusivamente de aspectos nacionais, na década seguinte, em parceria com produtoras de vídeo, a TV Manchete tenha exibido várias séries documentais sobre "outros povos". É a partir desse contexto que, no capítulo 4, analiso a série Japão, uma Viagem no Tempo (1985), dirigida por Walter Salles. Ao contrário das gerações dos capítulos anteriores, o Brasil aqui já não é tema de uma investigação do real, tampouco de desconstrução da linguagem documental. O vídeo, para alguns pensadores como Fredric Jameson um símbolo eminentemente pós-moderno, revelava-se o caminho ideal de ultrapassagem de fronteiras, linguagens, nacionalidades, a hibridização que é a marca da sociedade japonesa vislumbrada na série de Walter Salles. 


\section{1. \\ O discurso de sobriedade na década de 80}

1.1.

Os conflitos sociais filmados

Em uma das poucas críticas sobre Terra para Rose que encontrei nesta pesquisa, o autor estebelecia um nexo direto entre o filme de Tetê Moraes e Cabra marcado para morrer:

Há quatro anos, quando "Cabra Marcado para Morrer", de Eduardo Coutinho, foi apresentado no I Festival Internacional de Cinema, Televisão e Vídeo, no Rio de Janeiro, a emoção não ficou apenas na tela, na qual um filme [que] demorou 20 anos para ser concluído estendia-se mais do que apenas ao cinema: provocava a própria reunião de uma família separada pelo golpe de $1^{\circ}$ de abril de 1964. [...] De certa forma, a mesma emoção foi sentida por quem assistiu [...] à primeira exibição de "Terra para Rose", longa-metragem sobre o drama de milhares de famílias do Rio Grande do Sul, acampados na fazenda Anoni, durante meses, na luta pelo espaço para produzir e viver dignamente. ${ }^{29}$

De fato, se nos detemos exclusivamente na temática, Terra para Rose se insere na mesma tradição cinematográfica que o filme de Eduardo Coutinho, investigando a estrutura social brasileira com foco no campesinato, a luta pela terra e as relações sociais predominantes no mundo agrário. A expressão maior dessa cinematografia reside nos filmes que marcam o início do Cinema Novo, intitulados por Ismail Xavier de "Trilogia do sertão": Vidas secas (1963, Nelson Pereira dos Santos); Deus e o Diabo na terra do sol (1964, Glauber Rocha; e Os fuzis (1964, Ruy Guerra). Além desses clássicos, outras obras importantes bastante heterogêneas como O Pagador de Promessas (1962, Anselmo Duarte), $O$ Dragão da Maldade contra o Santo Guerreiro (1969, Glauber Rocha), O País de São Saruê (1971, Vladimir Carvalho), entre outros, fazem parte desse mesmo ideário. Ao analisar o espírito que permeava essa cinematografia, Marcelo Ridenti aponta que,

\footnotetext{
${ }^{29}$ MILLARCH, Aramis. "Terra para Rose, o documentário do ano". O Estado do Paraná, 25/10/1987.
} 
Os artistas engajados das classes médias urbanas identificavamse com os deserdados da terra, ainda no campo ou migrantes nas cidades, como principal personificação do caráter do povo brasileiro, a quem seria preciso ensinar a lutar politicamente. Propunha-se uma arte nacional-popular que colaborasse com a desalienação das consciências ${ }^{30}$.

Quando comparamos os filmes de Tetê Moraes e Eduardo Coutinho, apesar do conteúdo similar, é notório que os seus efeitos resultam um tanto distintos por conta de sua construções formais e das reflexões que nos possibilitam extrair. Inserido em uma prática cinematográfica militante, Terra para Rose está muito mais próximo de uma "arte nacional-popular com o objetivo de desalienação" que o Cabra que veio a ser concluído. Reflexivo, o filme de Coutinho se ocupa em vasculhar as lacunas históricas e pessoais de uma comunidade fraturada. A meu ver, em um caminho outro que o da crítica de Aramis Millarch, a análise dos dois filmes, bem como a dos demais, torna-se mais enriquecedora na sua diferença que na aparente semelhança.

Ao percorrer o conjunto de documentários apresentados nos três primeiros capítulos, fica patente que os principais personagens das lutas sociais do período, por caminhos completamente diferentes, constituíram a base desses filmes: Terra para Rose e Cabra marcado para morrer trataram do campesinato e a luta pela terra que atravessa a história do Brasil; Que bom te ver viva foi pioneiro na temática da guerrilha urbana. Pelas vias da rememoração e da reencenação, o filme de Lúcia Murat abordou os traumas de ex-militantes torturadas pela repressão do Estado ditatorial pós-64; Linha de Montagem deu prosseguimento a importantes obras como Greve! (1979, João Batista de Andrade) e Greve de março (1979), do próprio Renato Tapajós, registrando e trazendo às telas o vultoso operariado em luta do $\mathrm{ABC}$ paulista; Céu Aberto investigou o fato político desencadeado com a morte de Tancredo Neves. Vemos, no filme de João Batista de Andrade, tanto o "povo" 31 se manifestando quanto o pronunciamento de diversas figuras de destaque do âmbito político nacional, como Ulysses Guimarães e Fernando Henrique Cardoso. Mato eles? problematizou a

\footnotetext{
${ }^{30}$ RIDENTI, 2005, p. 87.

${ }^{31}$ Categoria controversa por seu caráter homogeneizador e pouco preciso, por vezes a utilizarei neste trabalho, sobretudo no filme de João Batista de Andrade, pois ali não se configura uma classe ou uma singularidade, mas uma coletividade genérica do tipo "populares".
} 
representação da causa indígena, assinalando o seu extermínio; Jânio a 24 Quadros compôs um mosaico de caricaturas de diversos personagens políticos a partir da figura de Jânio Quadros.

São obras inseridas, de modo direto ou indireto, nos debates públicos e disputas políticas que a redemocratização acarretou. Disputas que passam pela tentativa de invisibilização das minorias, dos trabalhadores do campo, da classe operária, enfim, dos que não detêm o poder no Brasil. Nesse contexto, a indexicalidade das suas imagens com o real torna o documentário um lugar privilegiado de representação e crítica às narrativas oficiais.

A grande distinção entre esse conjunto de documentários voltados aos conflitos sociais reside na sua forma de representação do real. Jean-Louis Comolli postula uma prática documental que não nega a realidade, ao contrário, constróise em fricção com ela, com todas as dobras e resíduos que possam transbordar para a cena fílmica. É a partir dessa postura estético-política que me oriento ao analisar os filmes a seguir.

Os documentários deste capítulo, apesar de o registrarem, fugiram do "risco do real". Como o fato político no qual estavam engajados (a luta do Movimento Sem-Terra, a formação do Partido dos Trabalhadores, a redemocratização pactuada) assumia a prevalência ante a sua construção formal, acabaram por reproduzir, em diferentes gradações, uma realidade objetiva, acabada. Neles, a persuasão do argumento impera sobre o risco de contradição do real. Não por acaso, são os documentários nos quais as vozes dos trabalhadores se encontram mais abafadas. Terra para Rose se propõe a ouvir os dois lados, mas, efetivamente, quase não ouvimos ninguém a não ser a narradora. Linha de Montagem ouve a classe trabalhadora, mas os operários se encontram submersos por seu líderes. Céu Aberto constrói um povo alienado e só ouve, de fato, os políticos com fins de mitificar a figura de Tancredo e, principalmente, contribuir no processo de redemocratização.

Começo, portanto, por esses documentários vinculados à lógica de sobriedade para, em seguida, atentar para outras formas documentais em que a mediação dos filmes, já esboçada em Céu Aberto, aparecem de formais mais vigorosa. 


\section{2.}

\section{Terra para Rose: a sobriedade na voz feminina}

Dirigido por Tetê Moraes ${ }^{32}$, Terra para Rose $(1987)^{33}$ conta a história de uma comunidade camponesa do sul do Brasil que, após longas e ineficazes negociações com o governo para conseguir um pedaço de terra, decidiu ocupar a fazenda Annoni, um dos tantos latifúndios espalhados pelo país. A ocupação assinalou um momento histórico, pois é considerada a parteira do Movimento dos Trabalhadores Sem-Terra (MST), tido como o maior movimento social a nível mundial nos anos 90 e extremamente relevante ainda nos dias de hoje.

Apesar de abordar de forma mais ampla a luta das 1.500 famílias camponesas ocupadas, o filme se concentra no papel da mulher enquanto liderança ativa do movimento. Rose (Roseli Celeste Nunes da Silva), a protagonista que dá nome ao filme, funciona como síntese das outras camponesas e também como fio condutor da narrativa: marca o começo do movimento ao parir a primeira criança (Marcos Tiaraju) daquela ocupação, presta o primeiro depoimento do filme, engaja-se fortemente na luta, não hesitando em momento algum com falas incisivas, e encerra o filme com sua morte.
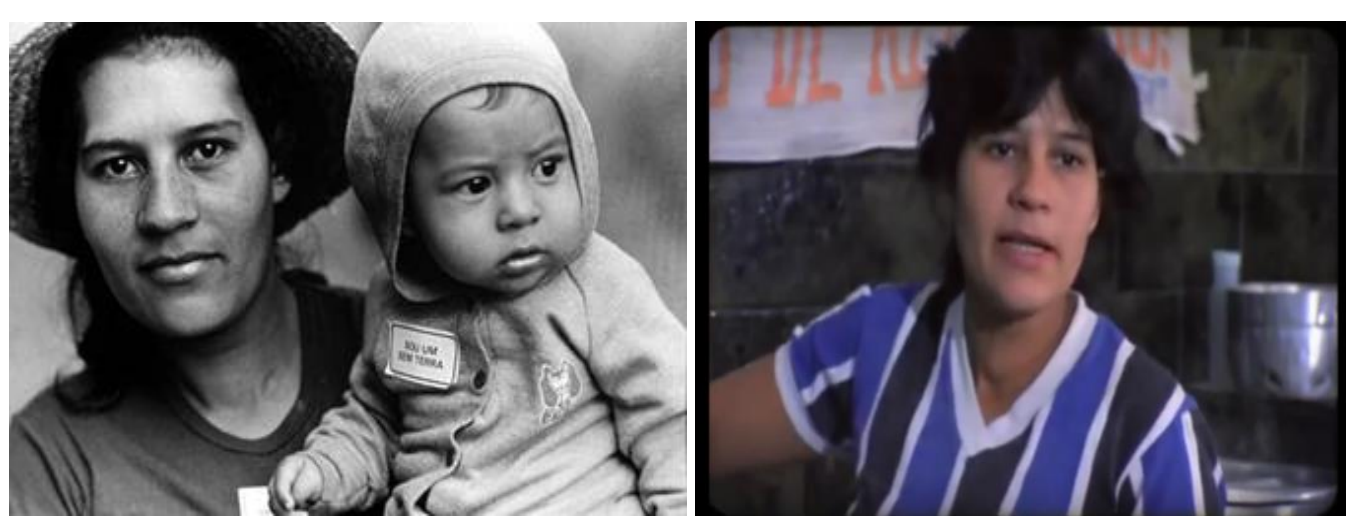

Fig.1. Rose, a heroína sem-terra.

\footnotetext{
${ }^{32}$ Em fins dos anos 60, Tetê Moraes foi diagramadora do jornal $O$ Sol, veículo de oposição à ditadura militar. Após ser presa pela ditadura, Tetê se exilou. (Mulheres do Cinema Brasileiro. Disponível em: www.mulheresdocinemabrasileiro.com.br/site/mulheres/visualiza/460/TeteMoraes/4. Acesso em: 08 abril 2018).

${ }^{33} \mathrm{O}$ filme foi distribuído pela Embrafilme. Em parceria com Tetê Moraes, José Joffily assina o roteiro e o texto de locução. Destaco os seguintes prêmios conquistados: Prêmio Gran Coral como Melhor Filme no Festival Internacional del Nuevo Cine Latinoamericano, 1987, Havana, CUBA; Melhor Filme de Longa Metragem em 16mm no Festival de Brasília do Cinema Brasileiro,1986; Prêmio Tatu de Ouro como Melhor Filme de Preferência Popular e Tatu de Ouro como Melhor Documentário de Longa Metragem, na Jornada Internacional de Cinema da Bahia, 1987.
} 
Terra para Rose se divide em cinco partes demarcadas em letreiros: $A$ promessa; A pressão; A espera; O confronto; e A trégua. Cada uma dessas partes encadeia a linearidade articulada no filme, estabelecendo um nexo causal com a seguinte em um adensamento da luta dos componeses para conseguir seu pedaço de terra.

O filme se inicia com um trecho dos sem-terra em marcha. Sobre uma ponte e em plano geral, vemos a multidão caminhando e cantando uma cantiga que tergiversa sobre libertação em meio a temas religiosos, expressão típica do catolicismo popular bastante difundido no Brasil pela Comissão Pastoral da Terra $^{34}$. Em seguida, aparecem Rose e os demais camponeses em plano fechado. A câmera se desloca e revela uma enorme quantidade de crianças e mulheres entoando o hino nacional. A introdução dessas imagens logo no começo do filme parece querer desmistificar as calúnias que o movimento dos sem-terra passaria ao longo de sua história. Ao contrário do recorrentemente noticiado pela grande mídia e difundido no senso-comum, não vemos "marginais", "vagabundos", ou qualquer adjetivação reacionária que pudesse caber naquelas imagens.

Logo após esses primeiros planos, surge o primeiro letreiro A promessa. Junto ao hino nacional cantado pelos camponeses que se mistura a outro não diegético, o filme insere imagens da bandeira nacional e do Palácio do Planalto. Em off, a narração dramatizada da atriz Lucélia Santos acompanha essa sequência introduzindo uma série de dados:

Brasil: $8.5000 .000 \mathrm{Km} 2,140$ milhões de habitantes, $8^{\mathrm{a}}$ economia do mundo capitalista, $5^{\circ}$ exportador de armas, estrutura fundiária arcaica. Dos 4.500 .000 de proprietários rurais, apenas 170.000 são donos de quase metade da área agrícola do país e contribuem só com $16 \%$ da produção agropecuária do Brasil. Há, pelo menos, 12 milhões de famílias de trabalhadores rurais sem terra. Foram assassinados mais de 1.000 camponeses nos últimos 20 anos. Entre 1970 e 1980, 24 milhões de brasileiros migraram do campo para as cidades. Esse quadro é de tal forma absurdo que hoje em dia quase praticamente ninguém se diz contra a Reforma Agrária. Mas cada um quer a sua e ela não acontece.

Esse gesto do filme marca um deslocamento marcante no campo documental.

\footnotetext{
${ }^{34}$ A Comissão Pastoral da Terra (CPT) é um órgão criado em 1975 pela Conferência Nacional dos Bispos do Brasil (CNBB) para combater as desigualdades sociais no campo e promover a luta pela reforma agrária.
} 
Conforme Bill Nichols assinala, a "voz de Deus" onisciente dos documentários clássicos estipulou um padrão de credibilidade fundado numa narração masculina, de tom grave e profissionalmente treinada ${ }^{35}$. Ao fazer uso do recurso com uma voz feminina por várias vezes dramatizada, o filme de Tetê Moraes rompia com aquela tradição do ponto de vista de gênero, ainda que, no tocante à estrutura do filme, mantinha-se alinhado à sobriedade da narração objetiva.

Através desse primeiro trecho narrado, a história nacional é convocada por um texto que não dá margens a dúvidas com inúmeros dados de um país extremamente desigual. Esse acúmulo de informações serve como ante-sala da saga camponesa que viria no decorrer do filme.

Em seguida, surgem imagens da posse de José Sarney ${ }^{36}$ acompanhadas por mais um texto em off que anuncia a "Nova República": "Março de 1985, primeiro governo civil depois de 20 anos de regime militar. Transição para a democracia. Esperanças, promessas, uma delas: fazer a reforma agrária". Durante toda essa longa sequência, alguns elementos, como a já referida bandeira nacional, a escultura feminina intitulada A Justiça e alguns sons extra-diegéticos, são recorrentemente acionados a nível simbólico numa montagem que articula incerteza e ironia. A Justiça representa uma mulher com olhos vendados carregando uma espada, símbolos da imparcialidade e da força. O tensionamento que o filme propõe em torno dessa imagem sugere questionar a noção de justiça acoplada à história oficial do país, pois, conforme sinalizado por Jacques Le Goff: "O monumento tem como características o ligar-se ao poder de perpetuação, voluntária ou involuntária, das sociedades históricas (é um legado à memória coletiva)" ${ }^{37}$. Esmiuçando o próprio monumento em si, evidenciam-se questões mais profundas da constituição política nacional, tendo em vista que, ao contrário da clássica imagem grega a qual faz referência, a versão brasileira abdicou da balança em favor apenas da espada e da venda.

\footnotetext{
${ }^{35}$ NICHOLS, 2005b.

${ }^{36}$ A figura de José Sarney é posta em vários filmes como símbolo da "Nova República". Tanto Terra para Rose quanto Céu Aberto e Jango, situam o primeiro presidente civil pós-64 de forma crítica. Gostaria de ressaltar, entretanto, que a entrada em cena de Sarney não opera uma mudança de qualidade do regime. Tanto por seu passado ligado à Arena (partido oficial do regime) quanto pela manutenção do sistema político instaurado com o golpe de 64, Sarney representa uma continuidade civil. A meu ver, uma mudança substancial só ocorre com a Constituição de 88 e a refundação do sistema político brasileiro. Embora os filmes assinalem Sarney de forma crítica, acabam por reproduzir a tese da ditadura terminada em 85 ao trabalhar com essas balizas temporais.

${ }^{37}$ LE GOFF, 1990, p. 536.
} 


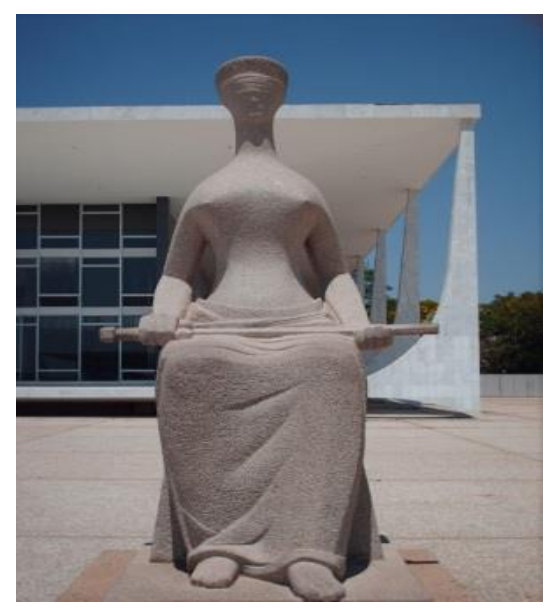

Fig.2. Estátua A Justiça.

Prosseguindo essa sequência, Sarney assinava o decreto da reforma agrária e, novamente, a imagem da estátua A Justiça era inserida em meio ao seu discurso, que se encerrava com a frase: "As origens do problema não são contemporâneos". Esta sentença surge como um convite a dialogar com o passado. Porém, ao contrário da perspectiva conservadora de Sarney que verificaremos mais adiante, o filme de Tetê Moraes o faz através do ponto de vista dos vencidos.

É o documentário Jango (Silvio Tendler, 1984), particularmente as imagens das imensas caravanas quando do tempo das Ligas Camponesas, que vêm após o discurso de Sarney, acompanhadas da narração sóbria de José Wilker a elencar as bases do governo de João Goulart: democratização da terra, voto dos analfabetos, controle dos aluguéis, aumento do salário mínimo, assinalando que “"Jango" propunha o fim da fome e da miséria num país onde a justiça sempre foi o lado obscuro da democracia”. Esse trecho é particularmente relevante. Vindo logo em seguida ao discurso de Sarney e às imagens d'A Justiça, a ponderação que "a justiça sempre foi o lado obscuro da democracia" estabelece um contraponto à oficialidade daqueles discursos/imagens e revela a disputa pela memória dos anos 60 que Terra para Rose assumia. Para tal, os arquivos fílmicos do documentário de Tendler são revolvidos de autenticidade comprovatória a fim de remontar o quebra-cabeças de uma luta que havia começado há muitos anos atrás e seguia sem resolução ${ }^{38}$.

\footnotetext{
${ }^{38}$ Jango (1984, Silvio Tendler) narrou a trajetória do personagem que dá nome ao filme (João Goulart), presidente deposto pelo golpe de 1964. Conforme explicitado no trecho narrado por
} 
Após as caravanas camponesas, assistimos às imagens do famoso comício da Central (Rio de Janeiro, 1964), no qual João Goulart assinara o decreto da Supra com vistas às desapropriações de terras, ato que no filme irrompe como ativador da contrarrevolução. Ao anunciar a chegada das tropas do general Olímpio Mourão Filho à Guanabara, o filme lança mão de um raccord $^{39}$ conectando os golpistas em marcha e o primeiro ditador pós-64, o general Castello Branco. Ainda com o general em quadro, ouvimos a continuação do discurso de Sarney, que surge em on declarando: "[...] foi o insuspeito presidente Castello Branco que sintetizou a concepção do problema no século XX através do estatuto da terra".

Esse é o ponto de vista conservador combatido pelo filme de Tetê Moraes. A quebra do discurso de Sarney, quando este proferira que "as origens do problema da terra não são contemporâneos", seguido de toda a contextualização histórica trazida pelo documentário Jango, com destaque para a conspiração golpista, resultam na total perda de credibilidade de sua conclusão sobre "o insuspeito presidente Castello Branco". Desse modo, a ditadura se apresentava como uma interrupção brutal das conquistas sociais entre os anos 50 e 60. E, ao louvar o primeiro dos ditadores pós-64, é o próprio presente encarnado em Sarney que se põe em questão. Segundo Andréa França, “[...] ao inserir o fragmento de Jango em meio às imagens da emissão televisiva, Terra para Rose revela a batalha pela memória travada nos domínios da comunicação de massa, a disputa em torno dos

Wilker, João Goulart procurou implementar uma série de reformas com vistas à ampliação dos direitos sociais e da própria democracia - as chamadas "Reformas de Base" -, entre elas, a reforma agrária, um dos motivadores centrais para sua deposição. $\mathrm{O}$ filme de Tendler, portanto, inserido no contexto da chamada "abertura democrática" e dos debates públicos sobre anistia, reparação, crimes de Estado, as "Diretas já", expressa a tentativa de clarificar o presente através da reconstituição da trajetória de Jango, o que, inevitavelmente, o levou a percorrer o acidentado processo de lutas sociais no Brasil que culminou com o golpe de 64. No que tange à linguagem, Jango articula entrevistas de personalidades públicas (ex: Frei Betto, Celso Furtado, Leonel Brizola), um vasto material de arquivo preservado por Tendler, e a narração em off onisciente. Estes recursos compõem uma argumentação bastante objetiva que consiste em ilustrar, através das imagens, a tese do filme ${ }^{38}$. Em conformidade com essa linha narrativa, o material de arquivo, no filme de Tendler, não passa por experimentações estéticas ou deslocamentos temporais, cumprindo o papel de atestação do argumento, isto é, como "prova histórica" do texto enunciado pelo filme. Jango se caracteriza, assim, como um documentário expressivo da sobriedade documental. Quer explicitamente por conta da sua incorporação no corpo do filme, quer implicitamente pela similaridade narrativa, é com o documentário de Tendler que Terra para Rose se conecta, e não com Cabra marcado para morrer, conforme sugerido pela crítica apresentada no começo deste capítulo.

${ }^{39}$ Raccord consiste em uma técnica de montagem articulando dois planos como forma de manter sua continuidade. 
usos das imagens de arquivo (do contexto da ditadura) no cinema, na televisão, na imprensa" 40 .
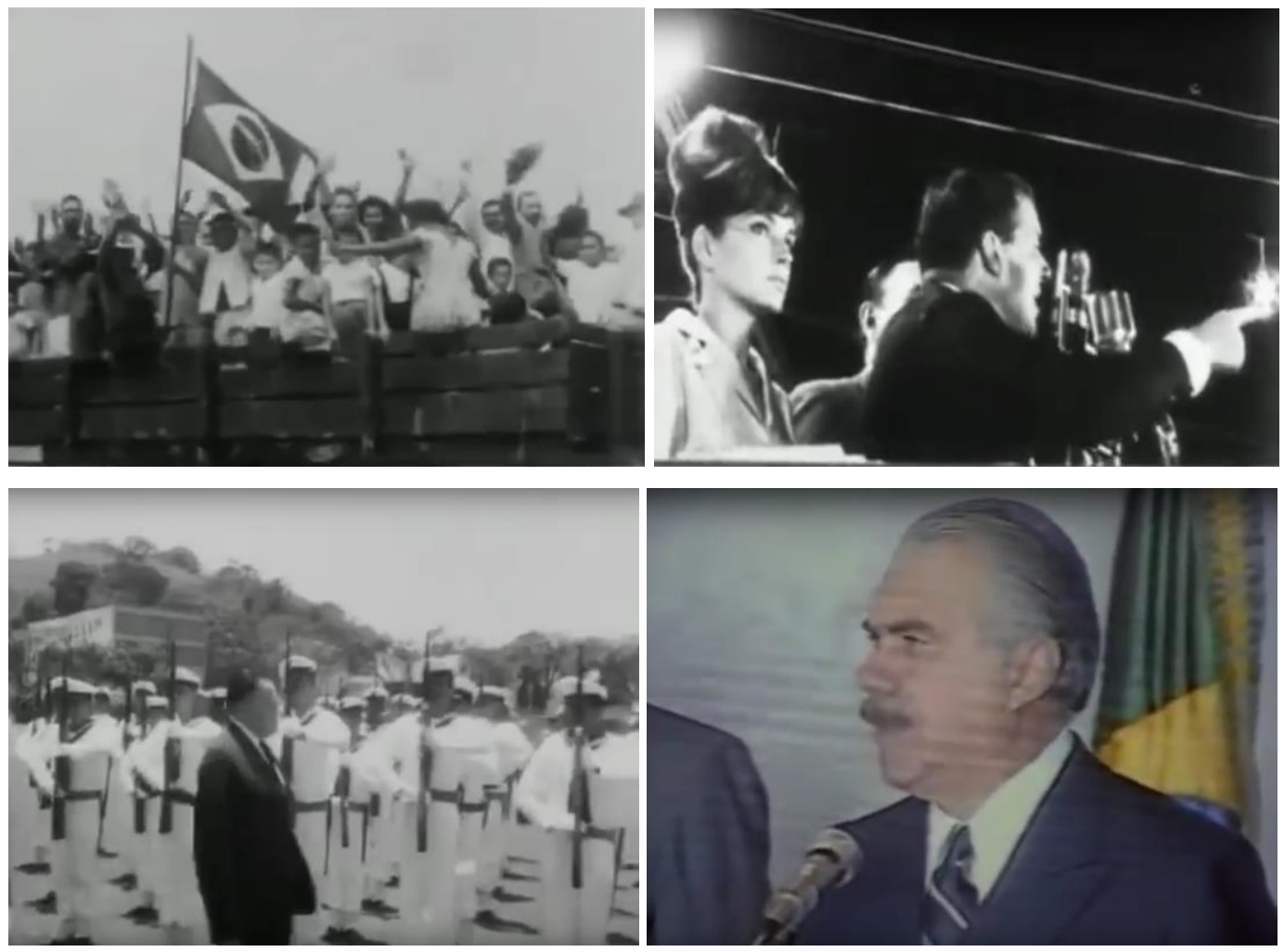

Fig.3. A batalha pela memória: o filme Jango e a posse de Sarney.

A montagem paralela de vários trechos do discurso de José Sarney/entrevista de Dante de Oliveira em contraponto às imagens de Jango, junto à narração em off e inserções de imagens e sons os mais variados, conduzem-nos a interrogarmos sobre o quê de novo a tão propalada nova República trazia para os trabalhadores do campo. Esse longo prólogo, além de situar de que lado o filme de Tetê Moraes se posicionava no conflito, introduz o argumento geral do documentário. Terra para Rose parte da permanência da injustiça sobre a questão agrária no país, a nível macro, para sua demonstração através da história de Rose e de seus companheiros ocupados na fazenda Anonni.

Terra para Rose constrói seu ritmo através de uma concatenação lógica e linear, valendo-se dos dois recursos centrais já apresentados no prólogo: a montagem paralela de uma série de trechos editados de depoimentos e entrevistas;

\footnotetext{
${ }^{40}$ Formulação esboçada numa conversa de orientação com fins de publicação de artigo científico sobre o filme.
} 
e a onisciente narração de Lucélia Santos, muitas vezes redundante com as falas dos camponeses ou asfixiante em relação às imagens capturadas.

Com frequência, a montagem paralela do documentário ativa o conflito como produtor de sentido. São vários momentos em que se estabelece uma oposição através de trechos editados dos depoimentos prolixos e hesitantes proferidos por representantes do governo, como o ministro Dante de Oliveira, ou o próprio Bolívar Annoni (proprietário da fazenda ocupada), e as camponesas sempre decididas e articuladas em sua batalha. Esse artifício ocorre logo na primeira sequência de entrevistas, na qual são colocados os antagonistas centrais do conflito: Rose e Bolívar Annoni. Este, ao ser perguntado sobre a desapropriação de sua fazenda, responde que não ouviu a pergunta. Um corte brusco põe em quadro Rose e seu filho. Ela explica que sua situação era muito precária e que seu grupo já estava organizado há três anos. Desse modo, quando se tentou expulsálos da terra, decidiram coletivamente ocupar a Annoni. Corte para Bolívar Annoni, que novamente é perguntado sobre como se sentiu pela desapropriação de sua fazenda. Um tanto desconcertado, gaguejando, responde: "Vamos, vamos começar primeiramente... No sentido de que, no, no sentido de que...”. Outro corte. Rose diz que não tinha medo algum da luta. A entrevistadora lhe pergunta sobre a opinião de seu marido e ela, de forma enfática, responde: "Ele não queria que eu fosse, daí eu disse 'Mas eu vou'. Ele disse 'Bom, tu que sabe, se tu quiser ir, se acha que pode ir...'. Eu disse 'Acha não, eu posso. E vou'”. Mais uma vez, a entrevistadora tenta a mesma pergunta com Bolívar Anonni, que tenta responder alegando que se tratava de um ato irregular. Porém, no meio de sua argumentação, hesita novamente e diz: "Me perdi nesse assunto aqui...”.

Rose, então, encerra essa sequência. Em seu relato, explica que, ao chegar no acampamento, a polícia tentou lhe impedir de entrar e ela respondeu: "Pra trás eu não volto, eu vou ficar aqui”. Dando continuidade, Rose relata que após um tempo de espera, finalmente, conseguiu ser liberada: "Dormi no chão, porque nem coberta nós tínhamos. [..] Eu, grávida, nos últimos dias pra ter o nenê. Acampei no dia 29 , quando foi dia $1^{\circ}$ de novembro eu ganhei ele. E correu tudo bem" ${ }^{41}$.

\footnotetext{
${ }^{41}$ A fim de evitar a poluição textual com ressalvas e sics, transcrevo os depoimentos dos filmes na íntegra. Além do mais, estando inteligíveis acredito ser importante politicamente mantê-los em sua integridade.
} 
Dentro do contexto de afirmação da luta que Terra para Rose assume, a justaposição de antagonismos exacerbados no filme busca a empatia/legitimidade dos discursos camponeses em detrimento dos que visam frear ou mesmo impedir a reforma agrária. Essa lógica de montagem, que abdica de continuidades espaçotemporais em prol da argumentação expressa pelo filme e da impressão de objetividade, é característica do modo documental expositivo sistematizado por Bill Nichols:

\begin{abstract}
A montagem, na modalidade expositiva, costuma servir para estabelecer e manter a continuidade retórica mais que a continuidade espacial ou temporal. Este tipo de montagem de evidência adota muitas das mesmas técnicas que a montagem clássica em continuidade, porém com uma finalidade diferente. De modo similar, os cortes que produzem justaposições inesperadas costumam servir para estabelecer pontos de vista originais ou novas metáforas $[\ldots]^{42}$.
\end{abstract}

Montagem de evidência, pois as "justaposições inesperadas", sustentando o argumento geral do filme, geram gradativamente no espectador tanto a necessidade de tomada de posição quanto de resolução do problema que é colocado. As sequências são montadas dentro de um esquema de causa-efeito através de uma composição lógica e linear daquela história. Desse modo, como o que prevalece é o texto que antecede a experiência, não nos causa estranhamento que Terra para Rose alterne, espacial e temporalmente, entre os mesmos gabinetes, acampamentos, e entrevistas editadas que retornam várias vezes. Essa lógica fica mais evidente na parte A espera, na qual, por três vezes seguidas, vemos imagens da ocupação em Porto Alegre e a narração nos informa que os sem-terra continuavam esperando alguma providência. Dessa forma, o filme almeja não possibilitar qualquer brecha contra os sentidos que propõe.

O momento mais expressivo em torno da montagem paralela do conflito ocorre após a reunião entre romeiros ${ }^{43}$ e deputados na Assembléia Legislativa de Porto Alegre. Um dos romeiros concede uma entrevista televisiva, cobrando a desapropriação e a posse da fazenda Annoni o quanto antes. Corte para a entrevista com Dante de Oliveira, na qual assinalava que todo cidadão tinha o direito de recorrer ao Poder Judiciário por seus direitos em um regime

\footnotetext{
${ }^{42}$ NICHOLS, 1997, p. 68. (tradução nossa).

${ }^{43}$ Como forma de pressionar o governo, os sem-terra fizeram uma longa romaria da fazenda ocupada até Porto Alegre (RS), percorrendo quase $500 \mathrm{~km}$ em 28 dias.
} 
democrático. E, concluía: “Cada ato desapropriatório do presidente da República não é o fim, mas, às vezes, é o início de um processo, de uma demanda judicial”. Em seguida, corte para a mesma entrevista com Bolívar Annoni. Este tenta argumentar culpabilizando a esquerda e a igreja que, em suas palavras, "estariam tentando desapropriar fazendas altamente produtivas". Prossegue dizendo que isso gerava uma situação muito difícil para sua classe e, mais uma vez, de forma desconcertante, perde o fio da meada e não consegue concluir seu raciocínio: "Hoje eu estou com a cabeça...". Corte para uma camponesa (não identificada no filme):

A Bíblia diz que a terra Deus deu para todos. A terra Deus não deu só pra uns tubarão, pra aqueles que podem. Pra criar inseto, pra criar fera, pra criar capim?! A terra é a coisa mais abençoada, é daonde nós tiramos o pão, pra sustentar os da cidade com o suor do nosso rosto.
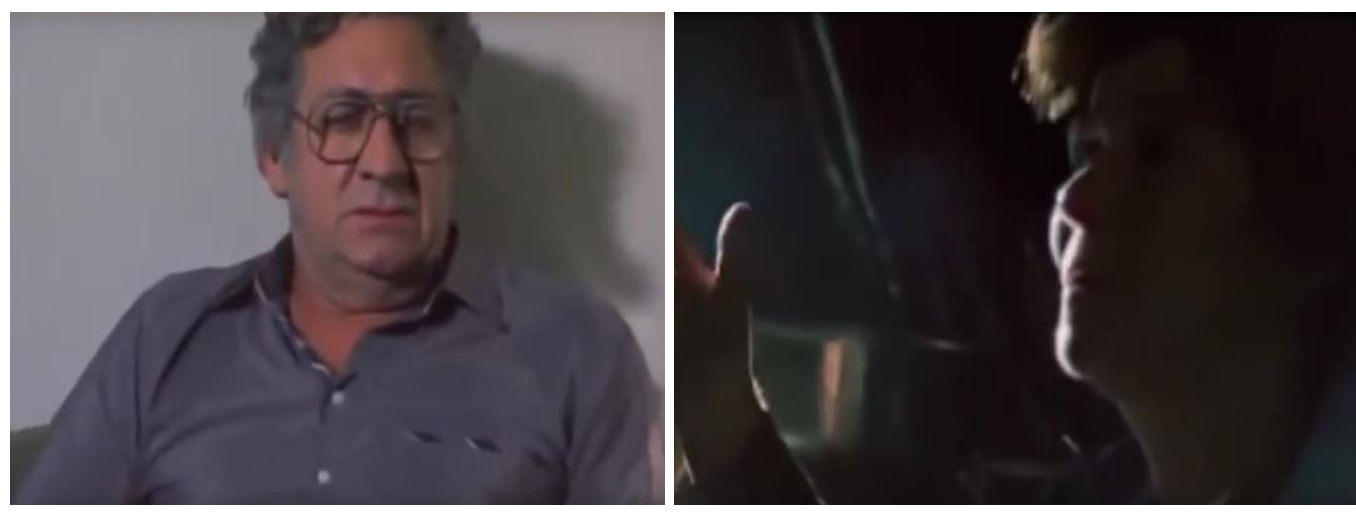

Fig.4. O conflito na montagem.

É importante notar a composição dessa sequência. Marcada pelos discursos de opostos, ela retoma, através da hesitante fala de Dante de Oliveira, o argumento da pouca vontade política de concretizar a reforma agrária colocado logo no começo e que atravessa todo o documentário. Por outro lado, ao filmar o inimigo o filme opta por ridicularizá-lo. Todas as vezes em que vemos Bolívar Annoni, são breves trechos editados nos quais ele se encontra débil, sem conseguir argumentar qualquer coisa mais consistente. Ridicularizando-o, o filme de Tetê Moraes vai na contramão do ato que Comolli sinalizou em potencializar o inimigo 
para melhor combatê-lo ${ }^{44}$. A própria morte de Rose sugere um tratamento outro que o enfraquecimento do inimigo filmado. É curioso notar também que o filme, mais uma vez, ressalta o "catolicismo rudimentar" da luta sem-terra através da fala que encerra essa sequência. Tendo em vista que na lógica de montagem persuasiva de Terra para Rose poderia constar qualquer depoimento, a retomada da dimensão religiosa traz à tona a importância do trabalho de base empreendido pelas chamadas "Pastorais da Terra".

Apesar de procurar emitir a potência dos sem-terra, sobretudo das mulheres, a voz destas no filme se encontra sufocada pelo enunciado geral assumido pela narração. É expressivo desta postura que quase nunca vejamos algum relato mais aprofundado $^{45}$ ou, mesmo, um pouco prolongado. Em conformidade com a montagem já assinalada, são inúmeros trechos editados de seus relatos com vistas a compor a concatenação do argumento do filme.

Ressalto um trecho por volta do minuto 16 do filme, no contexto da primeira ocupação de 50 famílias no Incra (Porto Alegre), ato que antecipa a grande romaria que viria a seguir. Em planos gerais da ocupação, o off de Lucélia Santos explica que esses primeiros ocupantes o fizeram para pressionar o governo. Vemos, então, imagens de três pessoas acordando, arrumando as suas camas, escovando os dentes, sob o texto: “A vida também começa cedo para Luci, seu irmão Zé e sua cunhada Cerli. Como tantos outros sem-terra, eles não querem migrar para a cidade". Em seguida, lavando roupas à mão, Cerli presta seu primeiro depoimento no filme, no qual diz que estavam ocupados como forma de exercer mais pressão sobre o governo e que só a luta poderia lhes proporcionar alguma coisa. Essa fala de Cerli sobre a necessidade de pressionar o governo acaba por redundar o texto narrado que abre essa sequência. Também não ouvimos nenhum dos três, neste momento, dizer que não gostariam de migrar para a cidade e, apesar disto poder estar implícito, soa artificial ser comentado por alguém que não os próprios. É só no minuto 47 que os três retornam na mesma entrevista editada e ouvimos Luci dizer que desejava seguir trabalhando na terra e não pretendia abandonar as suas raízes. Fica evidente que seus relatos funcionam

\footnotetext{
${ }^{44}$ Como filmar o inimigo? (COMOLLI, 2004).

${ }^{45}$ Uma das poucas exceções pode ser apreendida no trecho em que Rose explica a organização da cozinha na ocupação e detalha que eles, camponeses, têm o costume de comer um pouco mais que as pessoas da cidade por conta de seus hábitos de vida.
} 
como peças de uma engrenagem maior que lhes é exterior e não se põe em cena.

Em outra sequência assistimos à chegada dos romeiros em uma igreja. No que parece ser um bandejão, os camponeses se reúnem para comer e a narração, em tom dramatizado, assinala: “As promessas do governo não se concretizam, mas a solidariedade nasce nesse caminho. [...] Nas paradas em escolas, igrejas ou sindicatos, os $500 \mathrm{~km}$ que os separam de Porto Alegre se tornam mais curtos". Aspectos importantes como a solidariedade e a forma como ela se manifestara particularmente entre aqueles indivíduos, que poderiam ser apreendidos (ou não) "por nossa conta", observando as imagens e ouvindo os diálogos, são, desse modo, suprimidos e resultam como mera ilustração do texto narrado.

O direcionamento pela narração é um elemento fundamental de articulação do documentário com a lógica dos discursos de sobriedade. As palavras visam impedir qualquer possibilidade de abstração que as imagens "per si", sempre mais ambíguas (ainda que nunca isentas), poderiam incutir no espectador. Como o filme se preocupa centralmente em dar conta de forma objetiva de uma questão social candente, cada detalhe é orientado pela narração como forma de evitar as contradições do real.
A centralidade do argumento dá à banda sonora uma importância particular no documentário. Isso está de acordo com a relação entre o documentário e os discursos sociais de sobriedade que circulam através da palavra. As argumentações requerem uma lógica que as palavras são capazes de sustentar com muito mais facilidade que as imagens ${ }^{46}$.

Esse movimento, que poderíamos pensar como uma compressão das imagens e, por conseguinte, da experiência do outro filmado, não se restringe apenas à narração do filme. Em vários momentos de Terra para Rose, a prevalência do argumento se desloca para a própria montagem dos depoimentos. Ressalto o minuto 51, onde ocorre uma sucessão de breves trechos de relatos editados das camponesas, através dos quais se reafirma o companheirismo que aquela luta trouxe a suas vidas, e a necessidade de continuar lutando. Essa reiteração da palavra, muito próxima da informação jornalística ou da persuasão publicitária, soa como uma imposição de sentidos que o filme não consegue dar conta por sua ausência de diálogo com aquela realidade.

${ }^{46}$ NICHOLS, 1997, p. 51. (tradução nossa). 
Conforme Nichols assinala, no modelo expositivo os mais variados registros formam pilares de sustentação do texto do filme. Entretanto, o documentário de Tetê Moraes não se volta a um tipo social como nos filmes que Jean-Claude Bernardet teorizou acerca do modelo sociológico. Em Terra para Rose, pouco ouvimos sobre a experiência cotidiana no campo, além das imagens exibidas do dia-a-dia das pessoas serem exacerbadamente idílicas e, em geral, acompanhadas da narração como forma de impingir algum sentido. A argumentação do documentário, portanto, não se volta para as camponesas enquanto categoria social, mas para a luta do movimento sem-terra. Articuladas, narração e montagem visam, de forma didática, afirmar a luta dos sem-terra contra toda forma de omissão e repressão que constitui a sua história.

É por esse caminho que, em meio ao longo processo de luta e violência cotidiana que os ocupantes da Annoni sofreram pelas forças policiais e também por jagunços, vemos vários depoimentos que afirmam o sonho de conquistar a terra, coletivizá-la e estabelecer uma sociedade mais justa. Como exemplo, recorro a um depoimento de Rose feito quando da primeira ocupação em Porto Alegre, porém transportado para o fim do filme:

\footnotetext{
Meu sonho é a gente ganhar a terra, trabalhar... pra gente plantar, né?! E ter as criação, assim como a vaca, pra ter leite pros filhos. Criar galinha, ter a carne, que não precise a gente comprar, né?! E plantar todas as miudezas que daí os da cidade também vão pagar bem menos, porque agora é um absurdo o preço das coisas.
}

Adiante, Salete, uma professora camponesa, de forma lúdica, explicava o significado da palavra "terra" a algumas crianças numa sala de aula. O tom idílico de outras cenas retorna com uma harmônica canção sertaneja e planos gerais de Nova Ronda Alta. Esta é apresentada pela narradora do filme como o sonho da terra concretizado pela luta do primeiro acampamento sem-terra do Rio Grande do Sul, exemplo para os acampados da Annoni. Logo, Salete presta um depoimento no qual explica que, ali, o trabalho e o dinheiro arrecadado eram, ambos, coletivizados, encerrando com mais um discurso positivo:

E também uma grande bandeira de luta nossa é a luta pela reforma agrária. Porque, embora nós tenhamos um pedaço de terra, nós sabemos e temos consciência que temos muitos irmãos ainda sem-terra. Então, a nossa luta não terminou assim 
que nós subimos pra cima da terra. A nossa luta continua dando apoio aos companheiros da fazenda Annoni, dando apoio aos outros companheiros que ainda estão se organizando pra conseguir o seu pedaço de terra.

São exibidas imagens da fazenda Annoni sendo cultivada e a narradora do filme nos conta que, dias antes das eleições para a Constituinte, enfim, foi emitida a sua posse pelos ocupantes. Luci, uma das lideranças daquela ocupação, sublinha que ainda não era o ideal, mas que, depois de tanta luta, finalmente poderiam tirar o seu sustento. Um pouco mais adiante, a locução nos diz: "Mas nem todos poderão ficar na Annoni. A área cultivável só comporta 250 a 300 famílias. Onde irão os outros?". Neste momento, voltamos ao Palácio do Planalto para a posse de José Sarney. Logo, uma série de deputados, com a sua habitual retórica política, prestam depoimentos arguindo em prol da reforma agrária. O tom pouco convincente dos deputados é contrastado com a última fala ponderada de Luci: "A Constituição vai vir pronta praticamente. Vai ser muito difícil o trabalhador colocar aquilo que ele realmente quer na Constituição".
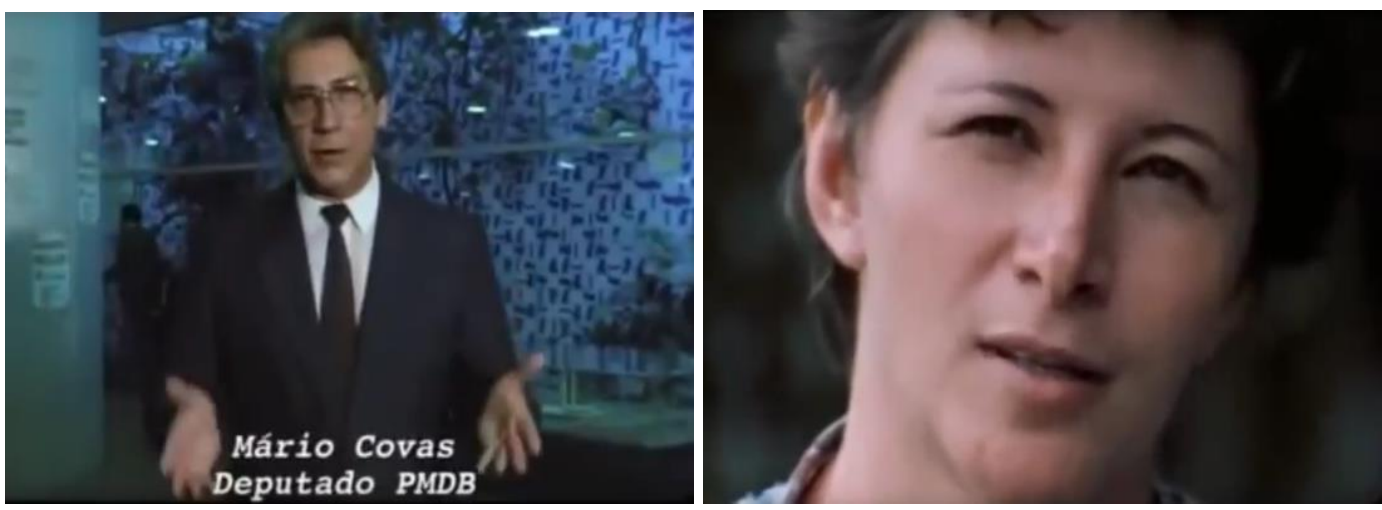

Fig.5. A retórica política e a desilusão com a Constituição.

Como forma de concatenar o argumento exposto no começo do documentário, voltamos ao mesmo cenário onde tudo havia sido apresentado e, em conformidade com a lógica inicial, a narradora apresenta uma série de dados conclusivos:

Em agosto de 87, quando fechamos este filme, das 1.500 famílias acampadas na Annoni, apenas 170 estão assentadas em 4 fazendas desapropriadas na região. 53 famílias ocuparam, em julho de 87, outra fazenda em desapropriação e lá estão acampadas. Na Annoni, continuam cerca de 1.200 famílias. Não se sabe quando serão assentadas. $\mathrm{O}$ primeiro plantio rendeu na colheita só a terça parte do esperado. Foi feito depois do tempo. 
A situação é de desolação e desespero. Algumas famílias acabam de tentar nova ocupação. A terra foi devolvida ao proprietário, os colonos reprimidos voltaram à Annoni, hoje, quartel general da esperança e desesperança. O ciclo trágico de novas ocupações, outras esperas, confrontos, deve continuar. Até quando?

Essa sequência, após perpassar a história do conflito na fazenda Annoni, não por acaso retoma e encerra os argumentos apresentados no começo do filme: a pouca vontade dos representantes políticos tornava a reforma agrária não mais que uma retórica política. Dentro desse contexto, o filme de Tetê Moraes coloca as reivindicações das camponesas como contraponto ativo à omissão dos poderes. Ao inserir essa fala conclusiva de Luci, o filme também desloca o tom religioso de outros depoimentos para um mais engajado e "consciente", como forma de dar mais consistência à luta.

É verdade que Terra para Rose cumpre um papel historicamente importante ao trazer para as telas o protagonismo das mulheres sem-terra. Embora o conflito pela terra tenha sido bastante retratado pelo cinema brasileiro, este, em geral, foi marcado pela figura masculina, expressando as dissonâncias de genêro mais amplas da sociedade. É verdade também que, como veremos a seguir nos relatos dos cineastas que cobriram as greves do ABC paulista, há uma ausência de cobertura midiática em torno das lutas sociais do período. Se essa situação era evidenciada no centro dinâmico de produção do país, é presumível uma maior gravidade em torno dos sempre esquecidos camponeses em luta nos rincões do Brasil. Ao longo do documentário, fica evidenciado todo um aparato de poderes midiáticos, econômicos e políticos que os camponeses têm de lidar cotidianamente em sua batalha. Em meio a essa situação, Terra para Rose se coloca como uma arma a serviço da luta camponesa. É marcante dessa postura assumida pelo filme o momento no qual os camponeses se dirigem à câmera para denunciar um companheiro ferido pelos policiais. 


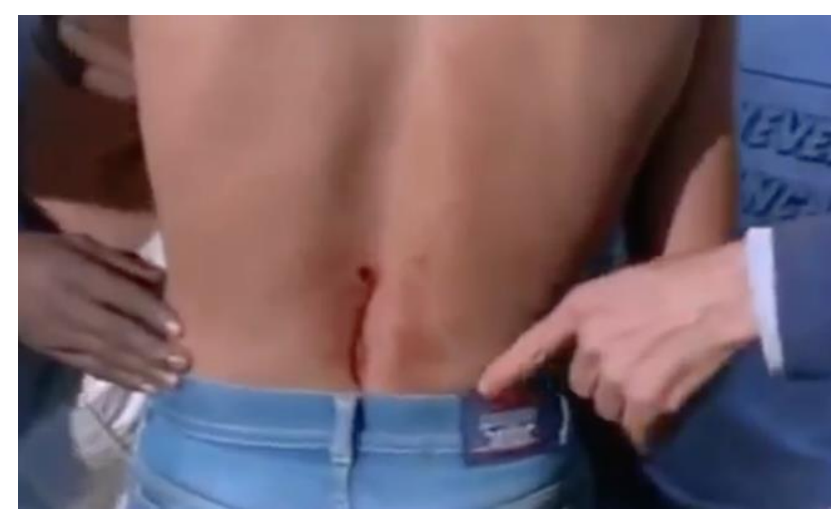

Fig.6. Sem-terra denunciam a repressão.

Porém, sob a égide da objetividade e do didatismo documental, o recurso da narração e a montagem em Terra para Rose acabam por asfixiar as falas das depoentes. Rose e as demais camponesas cumprem a função de atestação do argumento esboçado no começo e concluído no fim do filme, notadamente, a permanência das desigualdades sociais no campo e a necessidade da luta empreendida pelo Movimento Sem-Terra.

Mesmo se tratando de um documentário sobre aquela luta específica, a ausência de desavenças, contradições, hesitações, elementos que costumam estar presentes em movimentos sociais, torna pouco densa a experiência proposta pelo filme. A própria caricaturização do inimigo consiste em um recurso frágil para se compreender a complexa teia que envolve fazendeiros, poderes locais, forças policiais, jagunços, todo um aparato remanescente das oligarquias fundiárias que seguem reproduzindo a exclusão e a violência contra camponeses e indígenas no país.

Apesar de pretender singularizar o documentário em Rose, conferindo-lhe o título do filme, não é propriamente ela que vemos. Tampouco ocorre a busca pelo tipo social camponês ou a camponesa. O nome do documentário não deriva, portanto, nem de uma singularização nem de uma generalização, mas da homenagem prestada por conta de seu desfecho trágico. Após sabermos de sua morte na última sequência do filme, vemos imagens de Rose com seu filho e são editadas algumas falas, nas quais ela reafirmava o desejo de conquistar a terra com o governo, que iria continuar até o fim na luta e suas esperanças num futuro melhor para seu filho. Este encerramento adensa ainda mais o argumento do filme 
em defesa da luta camponesa, apesar de tudo o que eles sofreram e seguem sofrendo ao longo da história.

Terra para Rose é, portanto, uma espécie de "filme-manifesto", uma convocação à luta dos sem-terra. Narração, montagem e argumento se colocam como a própria evidência dos fatos, acoplados à realidade. De modo similar ao que Jean-Claude Bernardet observou acerca de Viramundo ${ }^{47}$, a atitude afirmativa e a coesão narrativa de Terra para Rose não permite que se ponha o filme em questão, no máximo a própria realidade, pois não há distância entre o filme e ela.

Atitude similar ocorre nos outros dois filmes deste capítulo, onde a busca por contribuir em determinado processo político resulta em representações menos densas que os filmes dos capítulos 2 e 3 . Contudo, há diferenças. Enquanto Linha de Montagem segue o mesmo caminho do didatismo de Terra para Rose, Céu Aberto já começa a pontuar mais a voz do diretor e seu sentido, ainda que seja o documentário menos "progressista", resulta um pouco mais aberto que nos filmes de Tetê Moraes e Renato Tapajós.

\section{3.}

\section{Linha de Montagem: "milhares de operários, um só homem”}

Uma questão fundamental atravessa as realizações de Linha de Montagem e Terra para Rose: a invisibilidade. Se o documentário de Tetê Moraes sinalizava a urgência na tomada e divulgação daquelas imagens, pondo-se como uma arma à causa dos sem-terra, Linha de Montagem não ficava atrás.

Em seu livro biográfico $O$ povo fala: Um cineasta na área de jornalismo da TV brasileira, João Batista de Andrade assinala a abstenção da TV brasileira em transmitir as imagens dos eventos emergidos com a classe operária em 1977. Em sua rememoração do período, João Batista assinala, inclusive, que um dos editores do Globo Repórter/SP, Georges Bordokan, enviou equipes de filmagem às greves e comícios, porém sem que suas imagens jamais fossem veiculadas ${ }^{48}$. Como contrapontos a essa postura, João Batista aponta o seu próprio documentário

\footnotetext{
${ }^{47}$ BERNARDET, 1985, p. 26.

48 "Essa postura, absurdamente absenteísta da TV, evidenciava, mais do que nunca, as amarras que a prendiam ao regime e a seu autoritarismo, agindo com estrita obediência aos desejos do governo, na contramão do que se passava na sociedade, a ponto de colocar em risco a própria credibilidade da instituição TV (carros com equipes de TV, que ainda filmavam, sem nunca levar ao ar as imagens, eram ameaçados e até apedrejados nas ruas pelos manifestantes" (ANDRADE, 2002, p. 116).
} 
Greve! (1979), e Greve de Março (1979, Renato Tapajós), "filmes que, substituindo a ausente $\mathrm{TV}$, foram exibidos ainda ao tempo da própria greve por todo o país e para os grevistas, com grande sucesso" ${ }^{49}$. Desse modo, fica patente a disputa política que os filmes realizados sobre as greves do ABC expressavam.

O contexto de perigo e caráter de "atividade subversiva" desses filmes podem ser mensurados pela trajetória incerta de Linha de Montagem. No filme Peões (2004, Eduardo Coutinho), descobrimos que por pouco o documentário de Renato Tapajós não foi apreendido. Quando da sua primeira exibição, em 1982, na sede do Sindicato dos Metalúrgicos de São Bernardo, agentes da Polícia Federal chegaram com ordens de apreensão. Após uma negociação, ficou acordado que o filme seria entregue às autoridades. Porém, contrariando as regras, o filme foi sacado pela janela do sindicato diretamente para a sacola de uma faxineira, Maria Elicélia Feitosa da Silva, que o encaminhou para outras mãos.

O depoimento de João Batista de Andrade e a tentativa de apreensão de Linha de Montagem expressam a subexposição assinalada por Georges Didi-Huberman como uma das formas midiáticas de eliminação dos "povos". Ao analisar o mundo contemporâneo, no qual as imagens assumem centralidade nas disputas políticas, Didi-Huberman atenta para uma questão fundamental em torno da visibilidade do outro:

\begin{abstract}
A subexposição simplesmente nos priva dos meios de ver aquilo do que poderia se tratar: basta, por exemplo, não enviar um repórter, um fotógrafo ou uma equipe de televisão ao lugar de uma injustiça qualquer [...] para que esta tenha todas as possibilidades de ficar impune e, assim, alcançar seu objetivo ${ }^{50}$.
\end{abstract}

Numa época marcada, por um lado, pela censura e repressão declaradas no campo político e, por outro, pela extrema concentração midiática que a ditadura impôs ao Brasil, a ação desses cineastas que filmaram os movimentos sociais se projetava como ato político de visibilizar o que os poderes tentavam esconder. Recém-saído da prisão por conta do seu envolvimento com a guerrilha urbana, Renato Tapajós se aproximou da militância junto ao Sindicatos dos Metalúrgicos de São Bernardo do Campo e Diadema e passou a registrar os principais eventos que ali eclodiam.

\footnotetext{
${ }^{49}$ Ibidem, p. 116.

${ }^{50}$ DIDI-HUBERMAN, 2014, p. 14, tradução nossa.
} 
Linha de Montagem pode ser melhor compreendido, então, se visto como o resultado de um longo processo de maturação da experiência do diretor com o operariado do $\mathrm{ABC}$ paulista. Iniciada ainda na década de 70 , essa atuação possibilitou a realização dos filmes Acidentes de Trabalho (1977), Trabalhadoras Metalúrgicas (1978), Teatro Operário (1979), Greve de Março (1979), e A Luta do Povo (1980) ${ }^{51}$. Inscrevia-se, nas palavras de Renato Tapajós, uma "função primordial" nesses filmes:

[...] esse cinema foi importante como registro histórico. Afinal de contas esses momentos estão lá, depois será possível recuperá-los através desses filmes. Agora, com a mudança da realidade política do país, a partir do momento em que, por exemplo, a televisão mostra a massa na rua, os comícios das Diretas, etc., esse tipo de filme, tal como ele era feito até então, começou a perder a sua função primordial ${ }^{52}$.

A “função primordial" que Tapajós menciona é a de contribuir, naquele contexto de fim dos anos 70 e começo dos 80 , com a luta política e a formação de unidade da classe trabalhadora a fim de obter suas conquistas imediatas e também pela derrocada da ditadura:

Os filmes sobre os movimentos operários foram necessários e importantes sob vários pontos de vista. Num primeiro momento, eles foram extremamente importantes como instrumentos de intervenção. [...] particularmente no final dos anos 70, era importante a gente pegar o conteúdo dos movimentos populares que estavam ocorrendo e devolvê-los ao público em filmes com um mínimo de interferência declarada do realizador. É claro, a interferência está lá, na escolha dos planos, por exemplo. Mas acho que naquele momento haviam questões que eram prioritárias, pelo menos eu as via assim. Quando começam as greves de 1978, 79 e 80, em São Bernardo, me parecia que o prioritário ali era discutir o processo de organização dos trabalhadores, devolver a eles essa discussão, permitir que os filmes alimentassem essa discussão. Isto era mais importante do que colocar explicitamente a minha opinião sobre a questão ${ }^{53}$.

Intervir colocando de forma mais reduzida possível a sua opinião, esse é o sentido que orientava basicamente os filmes de Tapajós quando dos registros do

\footnotetext{
${ }^{51}$ Para uma análise mais detida sobre esse conjunto de filmes de Renato Tapajós, ver a dissertação A luta operária no cinema militante de Renato Tapajós, de Krishna Gomes Tavares (2011).

52 "A hora da reflexão": Entrevista com Renato Tapajós, Filme Cultura, 1986.

${ }^{53}$ Ibidem.
} 
ABC. Pode-se perceber, portanto, uma mesma lógica em Terra para Rose e Linha de Montagem, os quais abdicam da confrontação com o real e de experimentações estéticas em prol da afirmação dos movimentos que registraram. Porém, a partir das Diretas Já, Renato Tapajós percebia uma transformação no cenário político com a mudança de postura da grande mídia que passou a filmar os principais eventos do país. Realizado em 1987, após as Diretas, a formação do Partido dos Trabalhadores, as eleições de 1985, o documentário de Tetê Moraes sinaliza para uma maior gravidade sobre a omissão da mídia em torno dos camponeses, traço que perdura até os dias atuais.

Lineares, valendo-se de entrevistas e registros como forma de encadear seus argumentos do começo ao fim, tanto Terra para Rose quanto Linha de Montagem se inserem na órbita dos discursos de sobriedade. A sua principal diferença reside na narração. Enquanto o filme de Tetê Moraes recorre largamente à voz off como forma de acentuar seu enunciado, em Linha de Montagem este recurso é utilizado com muito menos frequência. A persuasão, no filme de Renato Tapajós, deslocase, centralmente, para os depoimentos e a montagem. Ambos são documentários em que suas vozes ${ }^{54}$ se encontram acopladas ao real, movimento que Nichols observou através da compressão da voz do diretor, uma espécie de positivismo cinematográfico ${ }^{55}$ :

\begin{abstract}
Muitos cineastas contemporâneos parecem ter perdido a voz. Politicamente, renunciam à própria voz em favor da de outros (em geral, personagens recrutados para o filme $\mathrm{e}$ entrevistados). Formalmente, rejeitam a complexidade da voz e do discurso pela aparente simplicidade da observação fiel ou da representação respeitosa, pela traiçoeira simplicidade do empirismo não questionado do tipo: as verdades do mundo existem; só é preciso tirar-lhes a poeira e relatá-las ${ }^{56}$.
\end{abstract}

Linha de Montagem é um "filme-balanço" acerca das experiências

\footnotetext{
54 "Por 'voz', refiro-me a algo mais restrito que o estilo: aquilo que, no texto, nos transmite o ponto de vista social, a maneira como ele nos fala ou como organiza o material que nos apresenta. Nesse sentido, 'voz' não se restringe a um código ou característica, como o diálogo ou o comentário narrado. Voz talvez seja algo semelhante àquele padrão intangível, formado pela interação de todos os códigos de um filme, e se aplica a todos os tipos de documentário." (NICHOLS, 2005a, p. 50). Apesar de parecer uma definição pouco precisa, a voz do filme remete à tomada de posição, tanto em relação à perspectiva mais genérica que o texto manifesta quanto ao modo particular como ele é enunciado através da articulação das diversas vozes que o compõem. Assim, a voz se refere tanto à ética quanto à estética do filme.

${ }^{55}$ Sobre a relação entre a filosofia positivista e o campo documental, ver RUBY, 1977.

${ }^{56}$ NICHOLS, 2005a, p. 50.
} 
acumuladas pelas classe trabalhadora do ABC desde 1977, orientado-as, em sua construção narrativa teleológica, de modo a culminar com a fundação do Partido dos Trabalhadores (PT). O filme se concentra no processo de mobilização e crescente organização dos operários através das greves de 1979 e 1980, relatandoo primordialmente através do efeito de transparência emitida pelo registro dos eventos. Vemos, assim, diversas imagens de reuniões, comícios, piquetes, discursos em palanques, panfletagens em porta de fábrica, discussões dos trabalhadores. Em meio a esses registros, são inseridas entrevistas com as principais lideranças sindicais e alguns poucos operários "de base", os quais, através da enunciação direta de suas falas, relatam suas impressões, em geral, $a$ posteriori sobre os eventos que participaram. Embora a transparência do modo observacional prevaleça junto às entrevistas, outros recursos são utilizados conferindo maior objetividade ao filme, notadamente a narração sóbria do ator Othon Bastos, alguns letreiros informativos ou mesmo alguns depoimentos no calor dos acontecimentos.

Logo no começo do filme, vemos planos gerais do ABC paulista. Fábricas, multidões de operários, automóveis compõem o cenário industrial acompanhado de um texto narrado pelo ator Othon Bastos, o qual nos apresenta uma série de informações e estatísticas sobre a região e os conflitos:

São Bernardo do Campo, um dos municípios que integram o $\mathrm{ABC}$ na região da Grande São Paulo. São Bernardo do Campo, cidade moldada pela industrialização. Aqui está concentrada a grande indústria automobilística, carro-chefe da economia do país, responsável por mais de 10 por cento do produto nacional bruto. Nessas fábricas, de sofisticada tecnologia e de capital preponderantemente multinacional, trabalham cerca de 140.000 operários. Foram esses trabalhadores, que lutando por melhores salários e melhores condições de trabalho, desencadearam o movimento que chamou a a atenção do país para a situação da classe operária. As grandes greves de 1979 e 1980 colocaram os sindicatos dos metalúrgicos de São Bernardo do Campo e Diadema no centro das transformações que estão ocorrendo no movimento sindical brasileiro.

Em seguida, uma sirene convoca os trabalhadores e surge, então, um clipe com diversos planos-detalhe de operários dentro de uma fábrica automotiva ao som da música Linha de Montagem, de Chico Buarque, enaltecedora do trabalhador fabril. Essa sequência, que simula o labor repetido e árduo dentro da 
fábrica, termina com a realização do trabalho alienado daqueles operários, revelando uma imensa fileira de automóveis prontos para serem comercializados.
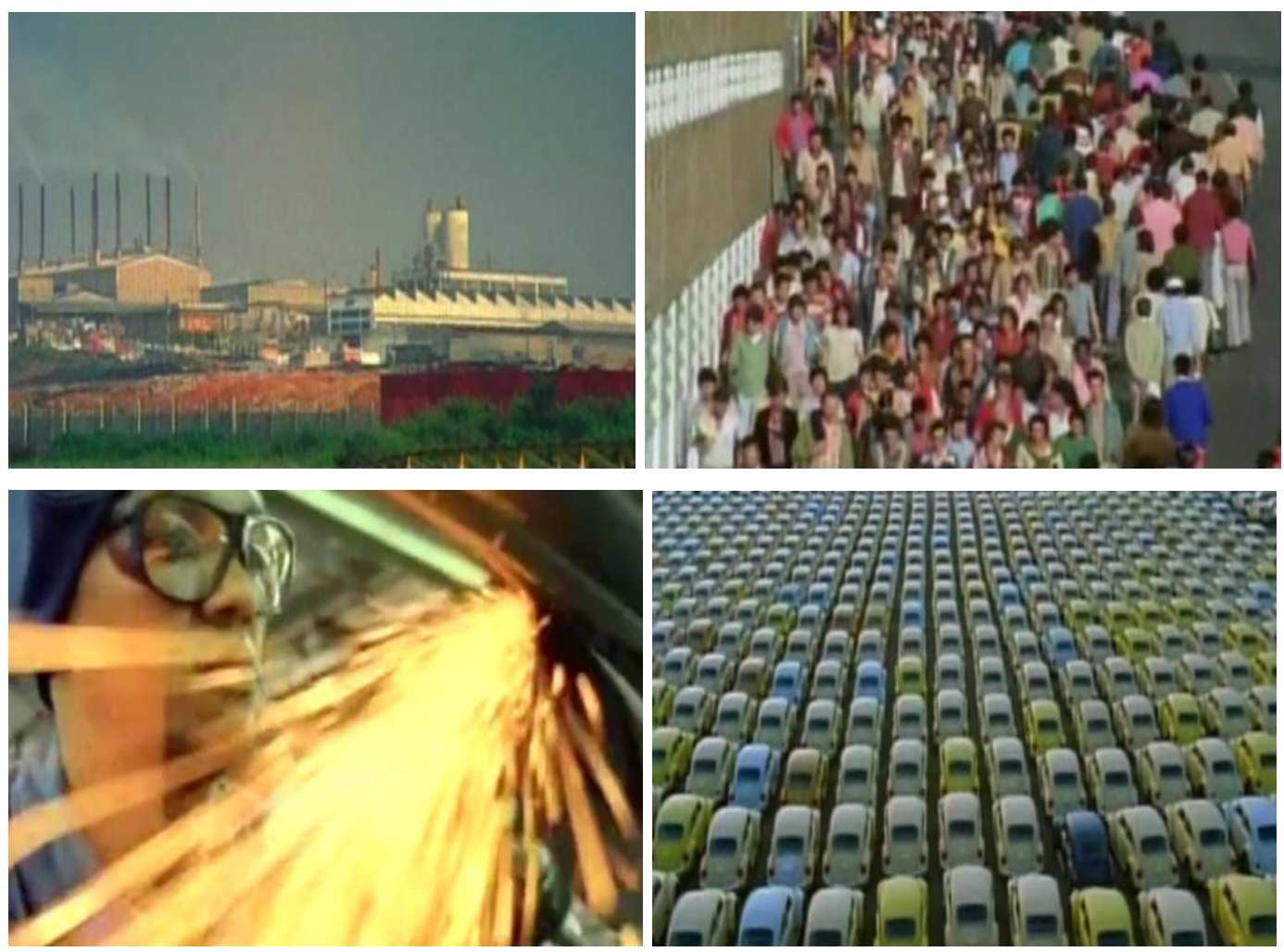

Fig.7. A sequência de abertura: $\mathrm{O}$ trabalhador e a realização de seu trabalho.

Tanto o momento narrado por Othon Bastos quanto o clipe descrito acima, que funcionam como prólogo do filme, são recursos persuasivos para que criemos empatia com os operários do $\mathrm{ABC}$, tendo em vista que nos é enfatizada, em textos e imagens, a sua importância na sociedade brasileira.

Logo após essa introdução, o primeiro depoimento que vemos é o de Luis Inácio Lula da Silva (Lula), principal liderança daquele movimento. Sua fala é de particular importância, pois, realizada em 1981, aponta o tom retrospectivo dos acontecimentos que o filme articula, além de propor uma coerência explicativa em torno dos mesmos. Elencando as principais reivindicações dos trabalhadores, como estabilidade do emprego e autonomia sindical, Lula enfatiza que o movimento já vinha de anos atrás e traça um histórico do movimento desde 1974 até a explosão da greve de 1979.

Em seguida, somos transportados ao passado a fim de verificar o argumento de Lula. Assistimos a imagens de um comício realizado em 1979, no qual Lula 
discursava para milhares de operários e, apontando a intransigência dos patrões em negociar, conclamava pela continuação da greve. Os trabalhadores, inflamados pelo potente discurso de seu líder, prontamente aderiam ao seu chamado e festejavam carregando Lula em seus braços. O narrador em off, então, anuncia: "Março de 1979, intervenção federal no sindicato dos metalúrgicos". Logo, surgem imagens de Lula sendo levado pelas forças federais, em meio a uma confusão generalizada por conta dos protestos dos operários. Essas imagens, em geral tremidas e misturadas ao "corre-corre" dos trabalhadores, causam uma sensação de experimentação ao vivo daquele conflito. São inseridos também sons não-diegéticos, como uma espécie de tambor, e algumas imagens são enfatizadas em planos detalhes, a fim de intensificar a dimensão da luta e da repressão policial. É interessante notar que, em meio à confusão, a própria equipe de filmagem transborda para a cena fílmica. A articulação desses mecanismos tende a revolver as imagens de maior autenticidade ao causar a impressão de capturar fielmente os eventos pela câmera.

Embora a equipe de filmagem apareça e as imagens demonstrem imperfeições por conta do ambiente tumultuado, isto não confere em si maior mediação do diretor no filme. Como demonstra Nichols, a tendência dos documentários vinculados aos estilo direto é diminuir "a distância entre o realismo fabricado e a aparente captura da realidade mesma" ${ }^{57}$. Nesse sentido, ao contrário de Cabra marcado para morrer, no qual a equipe e, sobretudo, o diretor, não apenas aparecem, mas estão em cena ativamente contribuindo na produção de significados, em Linha de Montagem a tendência é que esses momentos venham a reforçar a lógica de apreensão imediata da realidade:

Mesmo as marcas evidentes da textualidade do documentário som abafado, imagens desfocadas, figuras granuladas e fracamente iluminadas de atores sociais apanhados às pressas funcionam paradoxalmente. Sua presença é testemunho de uma ausência aparentemente mais básica: tais filmes sacrificam a expressão artística convencional, retocada, com a finalidade de trazer de volta em sua feitura, da melhor forma possível, a verdadeira textura da história. Se a câmera gira violentamente ou pára de funcionar, não se trata de expressão de um estilo pessoal. É sinal de perigo pessoal, como em Harlan County, USA [Barbara Kopple, 1976] ou mesmo de morte, como na cena de rua de La Batalla de Chile [Patricio Guzmán, 1973-

\footnotetext{
${ }^{57}$ NICHOLS, 2005a, p. 52.
} 
1979], quando o câmera registra o momento de sua própria morte ${ }^{58}$.

Essa situação paradoxal descrita por Nichols pode ser melhor apreendida no filme de Renato Tapajós em outro confronto entre operários e forças policiais durante a greve de 1980. Em determinado momento, um dos policiais diz à equipe de filmagem: "Vamos descendo, vamos descendo...", com a intenção de evacuar a área. Ouvimos, então, a voz de uma mulher membro da equipe dizer que estavam apenas fazendo a cobertura. A ação policial se torna mais ostensiva, chegando ao ponto de bloquear a filmagem com as mãos. Novamente, a mulher tenta negociar argumentando que faziam parte do sindicato. Um dos policiais parte de forma abrupta em direção a ela que, em tom apreensivo, diz: "Ei, nós estamos andando...". A sensação gerada nessa sequência, em meio ao tom de registro direto do filme, é de uma plena transparência do ocorrido.
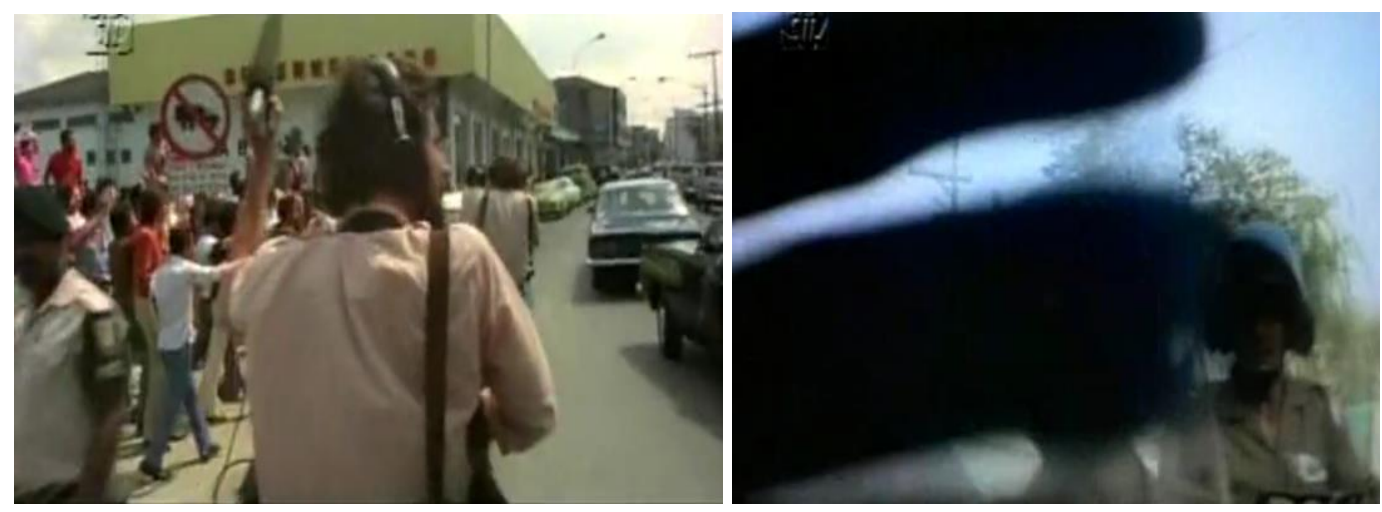

Fig.8. Equipe de filmagem em cena. Fig.9. Policial impede a filmagem do conflito.

Podemos apreender a forma como o filme concatena seu argumento no decorrer da sequência apresentada que iniciara com a convocação à greve feita por Lula e o subsequente conflito entre trabalhadores e policiais pelas ruas. Após o confronto, vemos mais um depoimento em retrospectiva, agora, de Djalma de Souza Bom (Diretor do Sindicato dos Metalúrgicos), relatando que a intervenção federal havia desarticulado por completo o movimento e assinalando a necessidade do retorno de Lula. Seu relato é seguido de imagens de Lula sendo carregado nos braços dos metalúrgicos após ser solto. O líder operário, então,

\footnotetext{
${ }^{58}$ Ibidem, p. 53-54.
} 
subia ao palanque e proferia um discurso no qual ressaltava a necessidade de três pontos fundamentais: (1) o retorno de seu sindicato com autonomia; (2) a reabertura das negociações em torno dos $11 \%$ reivindicados pelo movimento; (3) o recebimento dos dias em greve. Concluindo seu discurso, Lula afirmava a disposição do movimento em negociar e, sendo assim, convocava os trabalhadores a retornar ao trabalho durante 45 dias de trégua. Lula, mais uma vez, era aclamado pelos trabalhadores.

Adiante, somos conduzidos ao interior de uma fábrica, na qual operários trabalhavam. O narrador nos informa que, apesar da greve ter sido suspensa, os metalúrgicos se mantinham mobilizados em reuniões na Igreja Matriz de São Bernardo. Voltamos ao depoimento retrospectivo de Lula, que ressalta a importância da solidariedade ocorrida no dia $1^{\circ}$ de maio de 1979, “[...] quando centenas de categorias de trabalhadores, intelectuais, estudantes, compareceram ao ato [...] num instante em que nós estávamos em trégua”. Ao som da canção emblemática Cio da Terra (Chico Buarque/Milton Nascimento), apreendemos a solidariedade através de diversas imagens dos trabalhadores em comunhão num showmício com importantes artistas.

No que tange aos recursos formais, em toda essa sequência não há interferência explícita alguma do diretor. Quando Lula e Djalma prestam seus depoimentos, estes ocorrem através de sua enunciação direta para a câmera. Os outros momentos (o comício, as discussões sindicais na igreja, por exemplo) são articulados no estilo de registro direto. A importância dessa sequência reside em apresentar a linha argumentativa de Linha de Montagem. Resumidamente, a partir dos mais variados registros de que se vale, o que o texto do filme enuncia é um crescente de lutas dos metalúrgicos que, pouco a pouco, vão amadurecendo sua organização, passam pelo momento fundamental da criação dos comandos de greve por bairro, bem como do fundo de greve que lhes proporcionou maior autonomia, culminando com o momento político que resulta na criação do Partido dos Trabalhadores (PT).

O documentário, conforme explicitado pelo próprio diretor, era mais uma forma de contribuir na constituição de uma identidade de luta e resistência para os trabalhadores do ABC. Dentro dessa lógica, os dissensos, os questionamentos mais profundos, os chamados "rachas", aspectos que são naturais em movimentos de massa de largo alcance, são suprimidos do filme. O máximo que conseguimos 
apreender são algumas discussões em portas de fábrica, porém estas surgem de modo residual e o documentário de Tapajós tende a resolvê-las com um desfecho positivo para a luta dos grevistas. Em suas próprias palavras,

\begin{abstract}
Um problema que sempre me preocupou, que sempre criou dificuldades na realização dos filmes: a necessidade de a gente se ater a determinados aspectos da realidade para não prejudicar a função do filme, para não prejudicar aquilo a que o filme se destinava. Por exemplo, no filme sobre as greves de São Bernardo. De repente ocorrem divergências internas no movimento, há um racha na comissão de greve. Mas no filme esse racha está de fora, porque o que interessa para a utilização do filme é o processo de organização do coletivo ${ }^{59}$.
\end{abstract}

A "organização do coletivo" operada em Linha de Montagem passa por dois temas centrais que articulam as vozes no filme: por um lado, a criação do fundo de greve/comitês de bairro, por outro, o retorno da diretoria sindical cassada pela intervenção federal. $\mathrm{O}$ primeiro elemento começa a ser esboçado no filme com o fracasso da primeira greve ocorrida após os 45 dias de trégua, na fábrica Villares. Um operário não identificado no filme argumenta com Renato Tapajós (numa das poucas vezes em que o vemos, ainda que de forma rarefeita) que faltou politização àquela greve, que os operários não sabiam o que se passava e, portanto, não houve adesão. Em seguida, uma montagem paralela alterna planos de panfletagens na porta de uma fábrica bastante cedo convocando para uma assembleia, com uma reunião entre sindicalistas, na qual discutiam a falta de organização do movimento quando da intervenção federal e a necessidade de se criar um comando de greve por bairros. Este é um momento fundamental no filme que procura transmitir a maturação do movimento tanto na elaboração de um caminho organizacional de lutas quanto na própria ação dos que militam incessantemente no corpo-a-corpo com os demais trabalhadores.

Mais adiante, nos arredores da assembleia que viria, começa a se esboçar o outro argumento central do filme: a reivindicação pelo retorno da diretoria. Vemos, de forma caótica, um operário irritado que se dirige à câmera reivindicando os $11 \%$ de aumento que tinham direito. Outro, mais calmo, diz: "Eles têm que garantir que a diretoria vai voltar e os $11 \%$ também". Estes, ainda que breves, são raros momentos nos quais presenciamos os trabalhadores de

\footnotetext{
59 “A hora da reflexão”: Entrevista com Renato Tapajós, Filme Cultura, 1986.
} 
forma ativa no filme. Em geral, eles são representados enquanto uma coletividade expressiva, mas dependente de lideranças e seguindo suas diretrizes. Mais uma vez, é valioso perceber como Renato Tapajós vislumbrava a classe operária naquele período: “[...] em 1979/80, as nossas câmaras estavam retratando uma verdade, milhares de operários levantando os braços como se fossem um só homem, gritando uma palavra de ordem" ${ }^{60}$. Decorrem dessa visão, portanto, inúmeros momentos nos quais os trabalhadores são representados enquanto uma enorme massa amorfa que só fala ou levanta os braços quando convocada por seus líderes. Noutros, vemos alguns planos-fechados que expressam a sensação de incerteza e espera quanto ao retorno da diretoria sindical e o desfecho daquela luta.
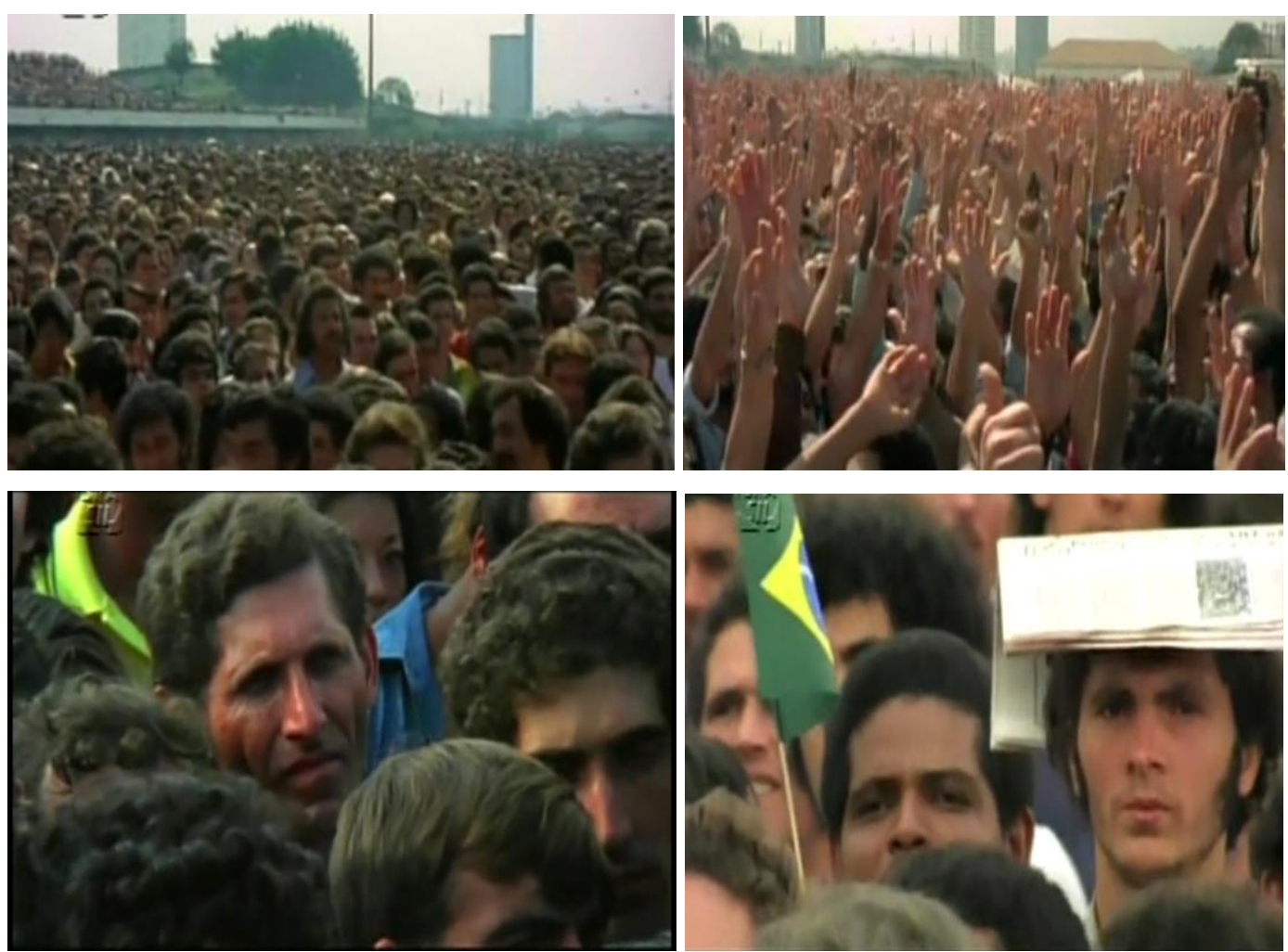

Fig.10. A classe trabalhadora por Tapajós: “milhares de operários, um só homem”

É importante atentar que, tal qual o trecho destacado sobre o operário irritado ante a câmera, há fissuras nessa representação. Destaco, sobretudo, a sequência na qual vemos o diretor sindical Djalma de Souza Bom, na porta de uma fábrica,

${ }^{60}$ Ibidem. 
convocar operários para uma assembleia. No decorrer dessa cena, Djalma assume o papel de entrevistador no filme e interpela um trabalhador se ele iria parar. De pronto, o rapaz lhe responde: "Eu sou o primeiro a parar". Djalma, então, lhe devolve outra pergunta: "Você é o primeiro. E se acontecer alguma coisa com o Lula, o que o trabalhador deve fazer?". O rapaz responde: “Os trabalhador, nós tem que ser unidos. Tem muito furão, mas nós dá um jeito neles". Assim, a narrativa seguia coesa até que o rapaz, então, profere: "Dessa vez, se nós parar, vai ser parado mesmo, hein! Ninguém vai voltar, não tem mais 45 dias, não. Nem 15 dias, nem nada". Djalma, que ali ocupava o papel de representante da diretoria, dá um sorriso meio sem-graça após a fala do operário e termina conclamando: “Trabalhador unido, jamais será vencido!". A fala daquele trabalhador se dirigia à trégua proposta por Lula que, no documentário, foi apresentada sem dissensos. Esse breve momento, portanto, revelava uma fissura na representação homogênea de adesão às convocações da diretorial sindical. É uma das raras vezes na qual um trabalhador fala por si.
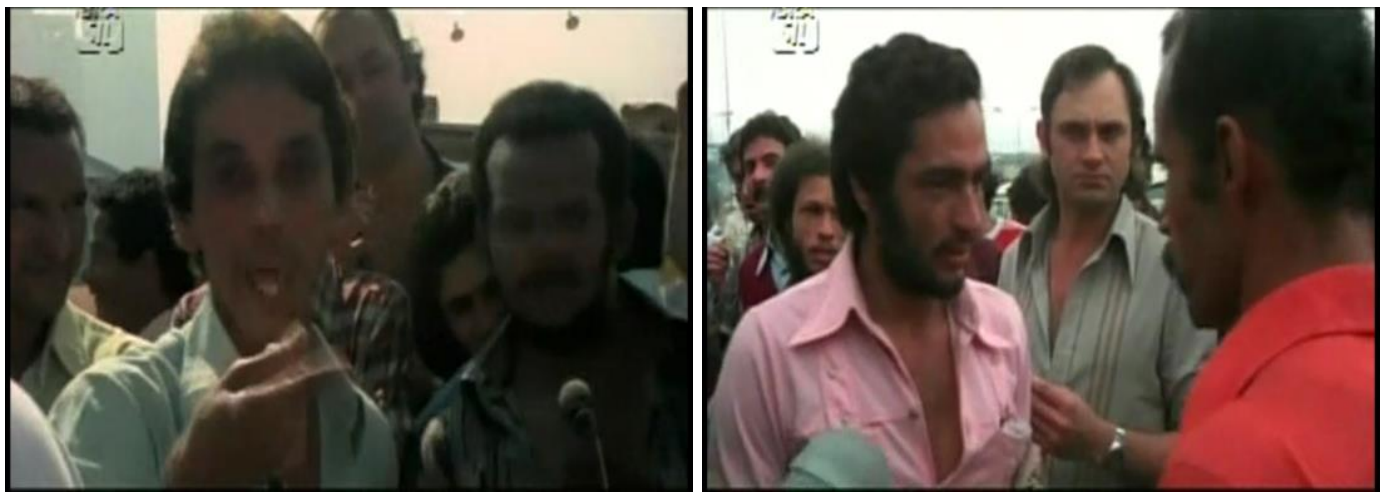

Fig.11. Fissuras na representação: operários colocam suas vozes

Embora quem fale em Linha de Montagem sejam predominantemente as lideranças sindicais, o documentário insere estrategicamente alguns depoimentos de trabalhadores de base como forma de dar consistência ao argumento geral do filme. Após o trecho do operário exaltado já mencionado, ainda nos arredores da assembleia, Linha de Montagem registra uma entrevista de Vagner Lino Alves (torneiro mecânico), na qual argumentava que a greve em si já era uma vitória, e que, embora o acordo fosse ruim, a luta continuaria e o mais importante era o retorno da diretoria. Após essa entrevista, já em cima do palanque, o sindicalista 
Enilson Simões de Moura, o “Alemão", reconhecia que o acordo era uma derrota para os trabalhadores, mas que o retorno da sua diretoria, naquele momento, era muito mais importante que o seu aumento. No mesmo palanque, Lula assinalava um ponto central no filme. Em seu discurso, o líder daquele movimento se justificava dizendo que, quem o vira na TV, percebera que ele "estava com o acordo pelo pescoço". Prosseguindo, enfatizava a importância do retorno da diretoria do sindicato e, contrariando as expectativas, argumentava que a greve naquele momento representaria uma derrota para o movimento, pois era preciso reunir forças para lograr uma greve vitoriosa mais adiante: “[...] Amanhã nós daremos uma lição ao Brasil e ao mundo. Nós voltamos a trabalhar com tranquilidade. Mas, num determinado dia, nós vamos voltar a agir. E agir com força total. É isso que proponho aos trabalhadores”. Lula, mais uma vez, conquistava o apoio da massa de trabalhadores.

Em seguida, vemos o segundo depoimento assinalado que vem a encerrar o sentido dessa sequência. Keiji Kanashiro (funcionário da Mercedes Benz), de modo retrospectivo, rememorava que havia ficado decepcionado com o acordo, pois achava que novamente a sua categoria havia sido traída. Porém, no momento daquele depoimento, Keiji percebia que havia sido a melhor decisão, pois naquela época eles não tinham a estrutura, a organização que alcançaram depois: "E, naquela ocasião, não havia realmente condições de continuar uma greve sem o sindicato na mão, sem o fundo de greve organizado". Em meio ao seu depoimento de Keiji, são inseridas algumas imagens de Lula ao fim da assembleia sendo festejado pelos trabalhadores.

De forma similar à Terra para Rose, o documentário de Renato Tapajós também justapõe imagens e depoimentos variados como recurso persuavivo, porém o faz de forma mais sutil, com menos edição explícita. Os depoimentos, em Linha de Montagem, são vistos de forma um pouco mais ponderada. Não obstante, a função é basicamente a mesma. A inserção de dois trabalhadores de base (Vagner Lino Alves e Keiji Kanashiro), o primeiro no calor dos acontecimentos, o segundo fazendo uma autocrítica de sua posição, cumpre o papel de referendar a posição assumida por Lula e ecoada no filme.

Aqui não cabe discutir se a posição de Lula foi acertada ou não, mas apontar como Linha de Montagem, ao contrário de Greve! (João Batista de Andrade), tende a mitificá-lo como porta-voz daquele movimento e líder nato. Além disso, 
são excluídas outras possibilidades e contradições de uma história que, narrada de forma teleológica, caminha para um fim previsto.

A voz da autoridade, no filme, reside centralmente na diretoria que é assinalada como mais que necessária para que os trabalhadores conseguissem se rearticular e, por conseguinte, em seu representante máximo, Lula. Nesse sentido, é sintomático que os depoimentos que o filme se vale sejam, em sua grande maioria, de diretores sindicais, bem como a constante exibição de Lula sendo aclamado pelos trabalhadores.

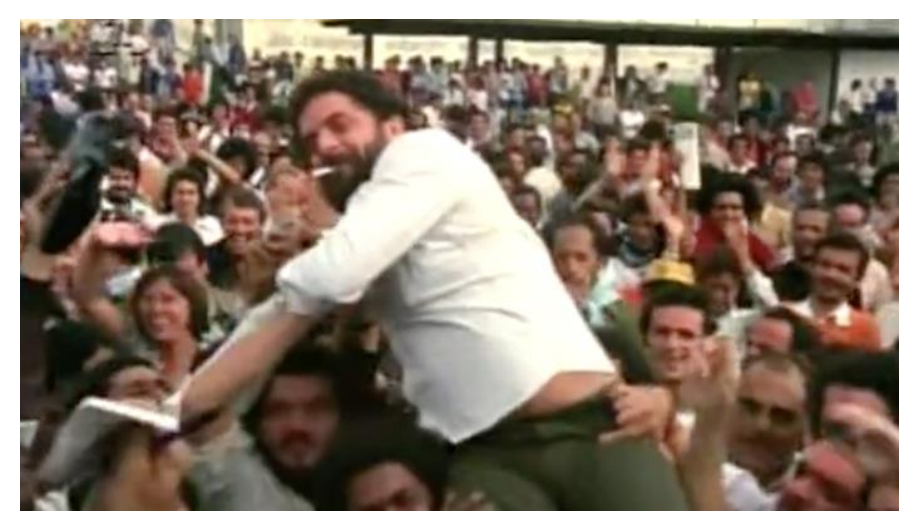

Fig.12. Um dos tantos momentos em que Lula é aclamado pelos metalúrgicos.

No dia 15 de maio de 1979, a diretoria reassumia o sindicato. Em seguida, os mesmos depoimentos retrospectivos do começo do filme (Djalma de Souza Bom e Lula) assinalavam a importância de se criar um instrumento que desse autonomia econômica à classe trabalhadora em sua luta. A saída encontrada foi a criação do fundo de greve através da Associação Beneficiente e Cultural dos Metalúrgicos de São Bernardo do Campo e Diadema. Este, nas palavras de Lula, "foi efetivamente o grande momento do nosso movimento". No dia 30 de março de 1980, em nova assembleia, Lula criticava os que diziam que os trabalhadores do ABC eram privilegiados e convocava-os a uma nova greve. Os operários atendiam ao seu chamado e, mais uma vez, em meio ao cerco do Exército, vemos diversas imagens de piquetes, discussões de trabalhadores em portas de fábricas, panfletagens, arrecadações de alimentos, discursos e mais discursos em assembleias. Numa reunião ocorrida dentro do sindicato, uma fala de Lula é particularmente relevante para o documentário, pois recompunha historicamente a luta sindical no Brasil e assinalava a relevância daquele movimento: 
[...] o que está impossibilitando os patrões de darem o aumento pra gente não é o aumento. Não é os $15 \%$, não seria até $30 \%$. O que está na cabeça de cada empresário, o que está na cabeça do governo, é a derrubada da diretoria desse sindicato. Porque, no Brasil, historicamente, toda vez que os sindicatos começaram a andar, o governo veio e podou. A partir de 64, o governo conseguiu o que queria. Ele conseguiu transformar cada sindicato desse Brasil num posto de atendimento médico e odontológico. [...] A partir de 77, São Bernardo mudou. Pra entrar de sócio do sindicato, precisava ter um pouco de fibra e ter disposição de brigar.

Lula seria preso no DOPS ${ }^{61} \mathrm{e}$, novamente, ocorria o confronto entre trabalhadores e policiais. O pouco que vemos ou ouvimos dos metalúrgicos são alguns trechos nos quais, num misto de revolta e desespero, aglomeravam-se reivindicando a liberdade de seu líder. Por outro lado, em uma assembleia, o filme exibe um discurso mais demorado de Dom Cláudio Hummes (Arcebispo de Santo André), no qual abria as portas da igreja aos trabalhadores e enfatizava que era muito importante que eles ficassem perto das suas lideranças: “[...] a única voz de vocês deve continuar sendo aqueles que aqui estão prepostos [...] através das lideranças de vocês mesmos". Ante uma multidão de trabalhadores apreensivos, a inserção dessa fala de Dom Cláudio Hummes vem, centralmente, a adensar a sua dependência da diretoria sindical.

Não por acaso, em seguida, o filme insere o coro dos operários por "Lula, Lula, Lula”. Novamente em seu depoimento retrospectivo, Keiji Kanashiro nos explica que, após a prisão de Lula, a greve cresceu, sobretudo, pelo trabalho de organização por bairros elaborado pelo fundo de greve recém-criado. Também retrospectivo, Lula relata que a diretoria sindical foi presa certa de que a organização de base deixada levaria o movimento adiante. E, prosseguindo, enaltecia a solidariedade de todos os segmentos da sociedade brasileira pelos trabalhadores do $\mathrm{ABC}$ : “[...] a vencer não apenas os empresários, mas também todo um regime que se colocava contra o avanço das nossas lutas". Esse é o momento de viragem que o filme busca caracterizar. Passava-se da fase econômico-corporativa para a luta efetivamente política. Desse modo, são exibidas inúmeras imagens retratando a dimensão da solidariedade que aquele

${ }^{61}$ DOPS (Departamento de Ordem Política e Social), órgão de repressão aos movimentos sociais, sobretudo, durante as ditaduras do Estado Novo (1937-1945) e empresarial-militar (1964-1988). 
movimento alcançou e, principalmente, introduzindo o nascente Partido dos Trabalhadores (PT). O depoimento final de Lula encerra o argumento geral do filme:

[...] o saldo mais importante que nós tivemos, na minha opinião, foi a descoberta da necessidade da organização política da classe trabalhadora. Porque, em todos esses anos de luta ficou provado de que tudo nesse país é decidido de acordo com as decisões políticas. Se tudo depende de uma decisão política, como é que a classe trabalhadora pode ficar sem tomar decisões políticas? Foi daí que a gente descobriu que era necessário [...] se organizar em um partido político. Então, acho que o saldo de tudo isso a gente, quem sabe, não colha ele hoje, e nem amanhã, mas eu acredito que a gente colherá ele, quem sabe, dentro de alguns anos [...]. Sindicalismo a gente faz pra tentar melhorar o relacionamento entre capital e trabalho. E política a gente faz pra transformar a sociedade.
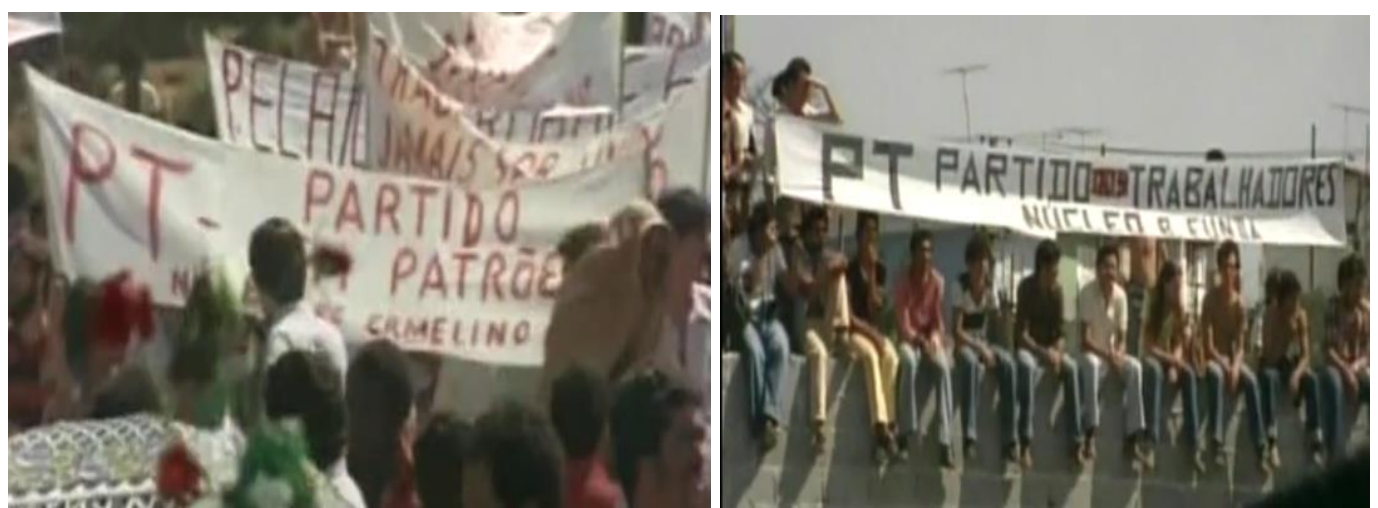

Fig.13. O nascimento do PT.

Em Linha de Montagem, a história é enunciada de forma utópica, como possibilidade vindoura de emancipação dos trabalhadores. Toda a retrospectiva empreendida pelo documentário de Renato Tapajós se orienta a apontar a mudança qualitativa que as sucessivas lutas proporcionaram aos operários do ABC. Ainda que existam pequenas fissuras, estas são dissolvidas na concatenação homogênea que o filme constrói sobre a maturação do movimento. Tal qual Terra para Rose, não se propõe que vejamos um filme, mas a própria realidade de forma unívoca. Realidade esta que, na verdade, escapa a ambos, pois não geram sínteses, mas enunciados externos.

E, embora possamos concordar com o argumento político e histórico do filme, a forma como ele se articula acaba por esvaziar os trabalhadores historicamente "sem voz", mas que naquele momento mudavam de postura e assumiam o 
protagonismo na sociedade brasileira. É verdade que em outros filmes, como Trabalhadoras Metalúrgicas (1978) e Greve de Março (1979), os trabalhadores têm maior destaque, porém, Linha de Montagem, já inserido na formação do PT, não almeja outra coisa senão afirmar a ascensão do líder político que viria a se tornar um dos presidentes mais populares da história da República. Por um lado, de forma mais problemática no que tange à voz do povo, por outro, mais complexo em sua constituição formal, o gesto de afirmação de um líder também é observado em Céu Aberto.

\section{4.}

\section{Céu Aberto: o mito e o "povo doente"}

Camponeses e operários, os pilares da sociedade brasileira, constituíram a busca dos documentários anteriores. Vimos, no entanto, a sua representação problemática orientada pela prevalência do argumento político em detrimento das contradições da realidade. Em Céu Aberto, como veremos a seguir, ocorrem mais fissuras na sua representação do real. Porém, inscrito no pragmatismo da transição à democracia negociada pela elite política do país, o filme de João Batista de Andrade ${ }^{62}$ é o que apresenta questões mais graves de representação dos trabalhadores.

Céu Aberto abordou a imensa repercussão causada pela morte do recém eleito presidente da República, Tancredo Neves, em 1985. Para além do registro dos fatos, o documentário procura investir na produção de sentidos que aquele fato político representou para o Brasil, valendo-se da articulação de inúmeros depoimentos de figuras destacadas do meio político brasileiro com a gigantesca mobilização de uma população que surgia desesperada nas ruas. O documentário de João Batista de Andrade pode ser visto como uma tentativa de raio-x daquele período crucial da história brasileira, tangenciando a campanha pelas Diretas-Já, o primeiro governo civil pós-64, os impasses da transição. Desse modo, a morte de Tancredo Neves consiste no elemento disparador que levou o filme a investigar a

\footnotetext{
${ }^{62}$ Segundo João Batista de Andrade, desde os tempos de universidade, o "veneno da política" circulava em suas veias (CAETANO, 2004, p. 10). Durante os anos 60, foi militante do Partido Comunista Brasileiro (o "Partidão") e, nas décadas seguintes, trabalhou tanto na TV quanto fora dela produzindo filmes voltados a aspectos sociopolíticos do país. Para uma leitura biográfica, ver João Batista de Andrade: Alguma Solidão e Muitas Histórias (CAETANO, 2004).
} 
correlação de forças, o papel do povo e os desdobramentos políticos naquela conjuntura.

Em Cineastas e Imagens do Povo, os documentários Liberdade de imprensa (1967) e Migrantes (1973), de João Batista de Andrade, são destacados por JeanClaude Bernardet por trazerem a presença do diretor à cena fílmica, intervindo no real e gerando novas sínteses decorrentes de sua ação. Ao contrário dessas obras, Céu Aberto se vale de menos intervenção explícita, estruturando-se através de um tom observativo sobre os eventos capturados pela câmera. Nas palavras do próprio João Batista de Andrade:

Eu via o país atravessando um momento épico curioso, único, carregado de contradições. E por isso quis fazer o filme como um épico, filmar em $35 \mathrm{~mm}$ e de uma maneira mais clássica, sem as correrias naturais em documentários ou reportagens sobre acontecimentos históricos. Eu queria um filme mais reflexivo e mais revelador ${ }^{63}$.

"A maneira clássica" se refere à postura objetiva do tratamento do real, sobretudo em torno das entrevistas e arquivos que não sofrem maiores problematizações no filme. Já o reflexivo, às articulações mais densas que o documentário propõe em sua montagem. Podemos pensar Céu Aberto através de três vozes fundamentais: a voz dos populares; a voz dos personagens políticos e outras figuras importantes na elaboração de conteúdos, como os diversos jornalistas que também prestam depoimentos no documentário; e a própria voz do filme que percorre todas as outras vozes de modo um tanto perplexo, como se buscasse apreender o mínimo de sentido em meio ao caos instaurado com a morte de Tancredo ${ }^{64}$.

Na primeira sequência de Céu Aberto, surgem imagens de uma multidão, em São Paulo, acompanhando o cortejo fúnebre de Tancredo. A comoção que a sua morte causara no povo é um dos temas centrais e, a meu ver, mais problemáticos do filme. Por ora, é preciso ressaltar que este prólogo se encerra com a imagem de

\footnotetext{
${ }^{63}$ CAETANO, 2004, p. 329.

${ }^{64}$ Assim, João Batista de Andrade descreveu sua busca: "Eu estou querendo é me apoiar nessa comoção e me perguntar, junto com todo mundo, o que foi que nos comoveu tanto. E é isso que o filme pergunta o tempo inteiro" ("João Batista e o episódio Tancredo", Zero Hora, Porto Alegre/RS, 29/05/1985).
} 
um militar, de costas e à certa distância, observando a multidão, imagem que acena para a superação do regime militar que João Batista procurou retratar ${ }^{65}$.
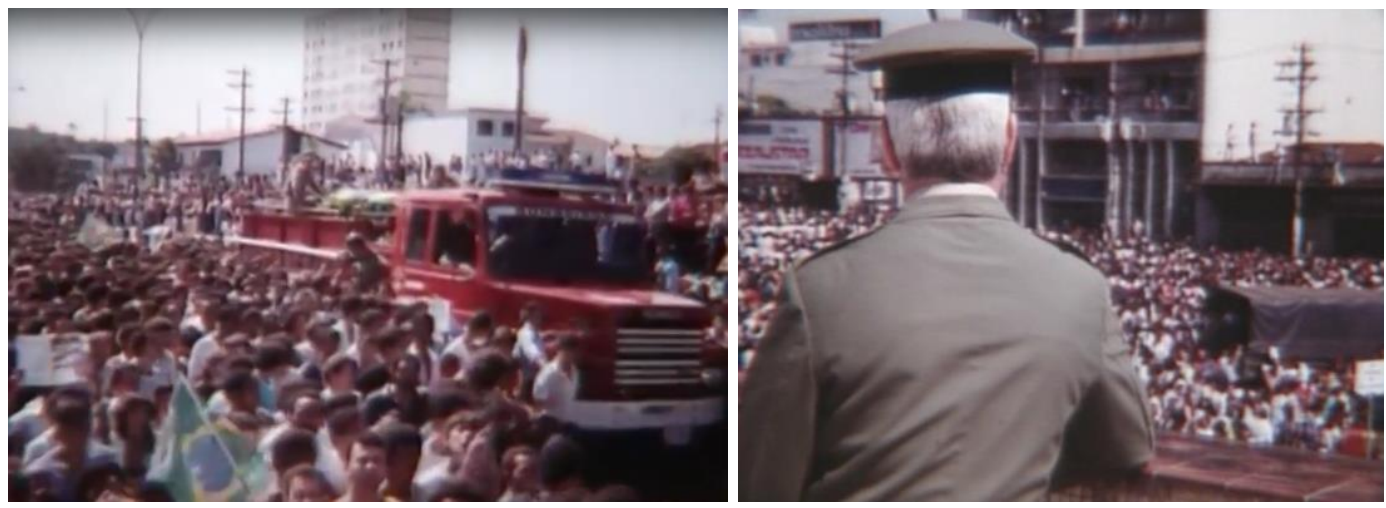

Fig.14. A sequência de abertura de Céu Aberto.

Em seguida, um avião nos transporta a São João Del Rey (Minas Gerais) e, através de alguns planos do céu, materializa-se o título do filme em alusão à frase proferida por Tancredo, "Ninguém conspira a céu aberto", quando das insinuações que a ala radical dos militares estaria conspirando um golpe contra sua candidatura à presidência da República. Em São João Del Rey, o documentário começa a articular as vozes recrutadas. João Batista pergunta a um jornalista local, Joanino Lobosque, como ele acompanhou a doença de Tancredo Neves. Em seu relato, Joanino diz que buscava concatenar os fatos que colhia pelas informações televisivas, apresentando a manchete que produziu quando soube da morte do então presidente eleito: “Tiradentes, Mártir da Independência; Tancredo, Mártir da Democracia". Joanino argumenta que a grande virtude de Tancredo era ser "um espírito nato de conciliação" e, dando prosseguimento ao seu relato, empreende uma breve trajetória de vida de Tancredo Neves, na qual reafirmava seus atributos políticos de inerente conciliador. Em meio ao seu relato, o filme insere algumas fotografias de Tancredo Neves, as quais cumprem o papel de atestação da biografia sintetizada por Joanino. É verdade que nesse momento João Batista esboça a "dramaturgia de intervenção", solicitando que Joanino rememore as idas e vindas da elaboração do jornal. Porém, esse recurso resulta menos

\footnotetext{
${ }^{65}$ Segundo o diretor: "Para mim, 'Céu Aberto' é um título que representa o momento de grande emoção que vivemos nos últimos tempos no Brasil, desde a campanha das diretas. É o povo na rua, é a esperança, é a liberdade, é a democracia. E ninguém mais do que Tancredo Neves simbolizou e cristalizou toda essa emoção e essa esperança [...]" ("Tancredo Neves em filme", Estado de Minas, 04/06/1985).
} 
vigoroso que em filmes anteriores, pois a cena se desloca para a objetividade do depoimento de Joanino através dos arquivos que a compõem.

A construção da figura de Tancredo como um grande líder conciliador prossegue na sequência seguinte através de um cinejornal que exibe uma massiva concentração política do PSD (Partido Social Democrático), em janeiro de 1964, na qual o então senador Juscelino Kubitschek e o deputado federal Tancredo Neves foram somar forças. Após percorrerem, em comitiva, a cidade de São Sebastião do Paraíso (MG), vemos Tancredo discursar sob a narração do cinejornal: "O senhor Tancredo Neves falou da sua posição a favor das reformas de base, mas dentro do mais absoluto respeito às tradições de nosso povo [...]”.

A seguir, é a historiadora e sobrinha de Tancredo, Lucila Neves, que presta seu depoimento no filme. Também em caráter biográfico, porém notadamente mais aprofundado, Lucila conta que Tancredo se formou na política do interior de Minas Gerais, mas que, rapidamente, foi alçado à vida nacional, tendo destaque nos governos de Getúlio Vargas, Juscelino Kubitschek e João Goulart. Já no período da ditadura, a historiadora sublinha que Tancredo soube se retrair, esperar o momento certo de lutar pela democracia através de sua concepção por um amplo acordo nacional. O depoimento de Lucila também é acompanhado de fotografias históricas de seu tio, as quais prosseguem ao fim de seu relato, em silêncio, numa sequência que evidencia Tancredo com políticos de posições as mais variadas, referendando o argumento de conciliação. Nesse sentido, até então, Céu Aberto parece encampar plenamente os depoimentos do filme que vêm a promover a mitificação da figura de Tancredo. Indo além, ao acoplar imagens de períodos diversos da vida de Tancredo Neves junto às narrativas sobre sua trajetória, o filme flerta com o perigo da "ilusão biográfica" exposta por Pierre Bourdieu ${ }^{66}$.

\footnotetext{
${ }^{66}$ Pierre Bourdieu sinaliza, de forma crítica, para as reconstruções biográficas que tomam um desde sempre que atravessa determinada pessoa e se confirma, de forma teleológica, em seu presente. (BOURDIEU, 2007).
} 

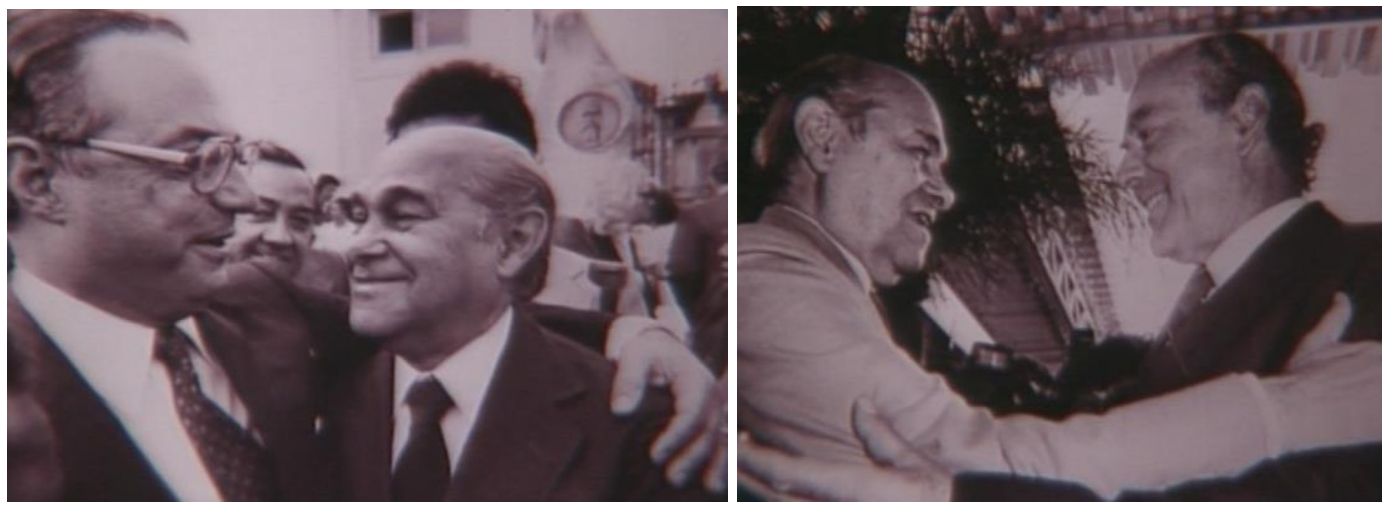

Fig.15. Sequência de fotografias evidenciando Tancredo Neves como um inerente conciliador.

Em seguida, ocorre um momento importante no filme. Em plano-fechado, a câmera percorre as expressões de algumas pessoas que nos dão a sensação de estarem atônitas, pois é inserido um áudio com caráter altamente científico no qual se explicava tecnicamente como ocorrera a operação de Tancredo Neves. Com esse recurso, o filme já apresentava uma de suas principais considerações sobre aquele momento: uma população que assistia a tudo "bestializada" ${ }^{67} \mathrm{e}$, dessa forma, o seu desespero com a enfermidade de Tancredo era a própria expressão da sua falta de agência nos rumos do país que se abria. João Batista de Andrade detalhou suas impressões sobre aquele momento:

\begin{abstract}
Ao filmar o povo ali amontoado, carente, curioso, ouvindo a ladainha médica a respeito da saúde do Presidente, com os incompreensíveis termos médicos, a visão que eu tinha é que aquele povo é que estava doente, buscando uma cura, uma mão santa que os pudesse livrar do mal crônico da falta de perspectiva $^{68}$.
\end{abstract}

$\mathrm{Na}$ entrada do hospital, uma imensa população em preces se amontoava no local amplamente rodeado por jornalistas. A própria câmera de Céu Aberto expressava o caos do momento, oscilando num ir e vir entre aquelas pessoas que rezavam incessantemente e o falatório das coberturas jornalísticas. Inicialmente, a câmera se decide pelo povo e passa a investir em travellings percorrendo seus

\footnotetext{
${ }^{67}$ Faço alusão direta ao depoimento do propagandista Aristides Lobo citado por José Murilo de Carvalho em Os Bestializados: O Rio de Janeiro e a República que não foi (CARVALHO, 1987), no qual já se colocava a ideia de um povo alheio às transformações políticas ocorridas quando da República.

${ }^{68}$ CAETANO, 2004, p. 330-331.
} 
corpos. Em seguida, opta pelos jornalistas e a montagem tumultuada, num dos momentos de quebra sutil do efeito de transparência, procura assinalar a desorientação que tomava conta daquele ambiente.
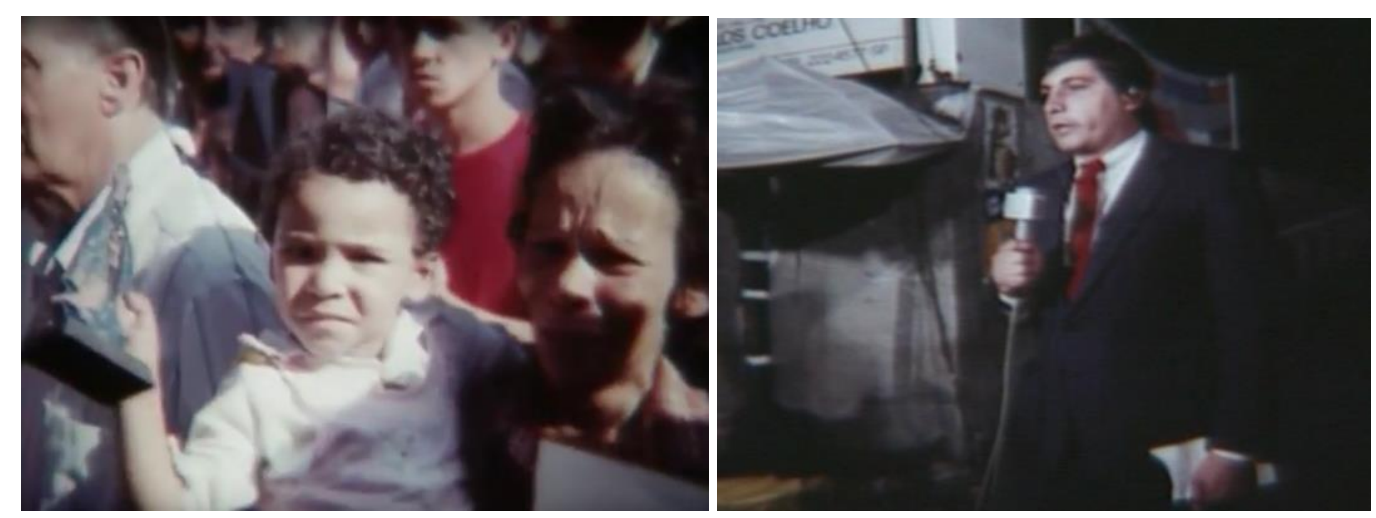

Fig.16. O povo desesperado, a mídia desorientada.

É só na próxima cena do filme que a figura de Tancredo é matizada. Em seu depoimento, o cartunista Chico Caruso caracterizava Tancredo Neves como uma figura discutível politicamente, pois havia persistido na conciliação entre MDB e ARENA: “A sua própria fisionomia, o seu jeito de bom velhinho, acaba cativando as pessoas [...] ele acaba sendo a síntese da saída política que o Brasil encontrou naquele momento". Através do depoimento de Chico Caruso não é apenas a figura de Tancredo que passa por uma problematização no filme, mas também a saída pactuada que fora idealizada por Ernesto Geisel quando este assinalou a "transição lenta, gradual e segura”. Desse modo, embora Tancredo permaneça positivado em Céu Aberto, sobretudo porque são inseridos outros tantos depoimentos a enaltecê-lo, a voz do filme procura se afastar de uma total adesão à sua trajetória. Apesar da sua pública admiração por Tancredo Neves ${ }^{69}$, essas pequenas fissuras expressam uma forma indireta de João Batista de Andrade tentar se colocar de forma autônoma: "No futuro, este será o único material filmado sobre os acontecimentos. Mas não é um filme Tancredista, eu não estou vendendo o peixe do Tancredo" 70 .

\footnotetext{
69 "Eu aprendi, no processo de abertura política, a admirar Tancredo Neves, achava que ele conduzia esse processo como um mestre, orientando nosso barco com sabedoria, em meio a tantos perigos de fracasso e de retrocesso. Nós todos tínhamos participado da luta pelas "Diretas-já" e sofremos todos com a derrota da emenda Dante de Oliveira no Congresso Nacional" (CAETANO, 2004, p. 328).

70 “João Batista e o episódio Tancredo", Zero Hora, Porto Alegre/RS, 29/05/1985.
} 
Essa mesma situação pode ser percebida na sequência que surge logo após a imagem de Tancredo morto. No Palácio do Planalto, a montagem do filme alterna planos de seu velório com alguns depoimentos nos arredores. O primeiro entrevistado é Fernando Henrique Cardoso (senador pelo PMDB), que enaltece Tancredo como um "símbolo da negociação sem abaixar a cabeça, da democracia" e assinala que, se a nova República fosse construída sob os seus ideais, Tancredo Neves se tornaria um mito que se martirizou pelo Brasil. O segundo entrevistado é Eduardo Suplicy (deputado pelo PT), a voz dissonante a apontar que o "espírito de conciliação" de Tancredo Neves o levava, sempre, a ouvir antes os detentores do capital que a classe trabalhadora. Em seguida, o velório é observado de forma mais detida no filme e surgem mais depoimentos vangloriando o legado de Tancredo Neves.

Ao contrário de Terra para Rose, que produz sentidos através do antagonismo explícito na montagem dos depoimentos, em Céu Aberto, as poucas vozes dissonantes surgem como pequenas brechas, porém diluídas na argumentação geral. Dessa forma, a fala discordante de Eduardo Suplicy é inserida em meio a outras tantas que seguem uma argumentação similar. Abafando ainda mais o dissenso, essa sequência culmina com o bem mais demorado depoimento de Ulysses Guimarães (presidente do PMDB), que, de modo categórico, engrandecia a figura de Tancredo Neves. Aqui, há um momento que merece ser destacado. Durante o seu relato, também são inseridos arquivos, porém, no trecho em que Ulysses assinala o "discurso corajoso" proferido por Tancredo quando da morte de Getúlio Vargas, as imagens deixam de ser apenas ilustração de seu depoimento e passam a ser exibidas integralmente. É o documentário Glória e Drama de um Povo (1956, Alfredo Palácios), que através de uma narração dramatizada, apresentava a comoção popular em torno do suicídio de Getúlio Vargas. 

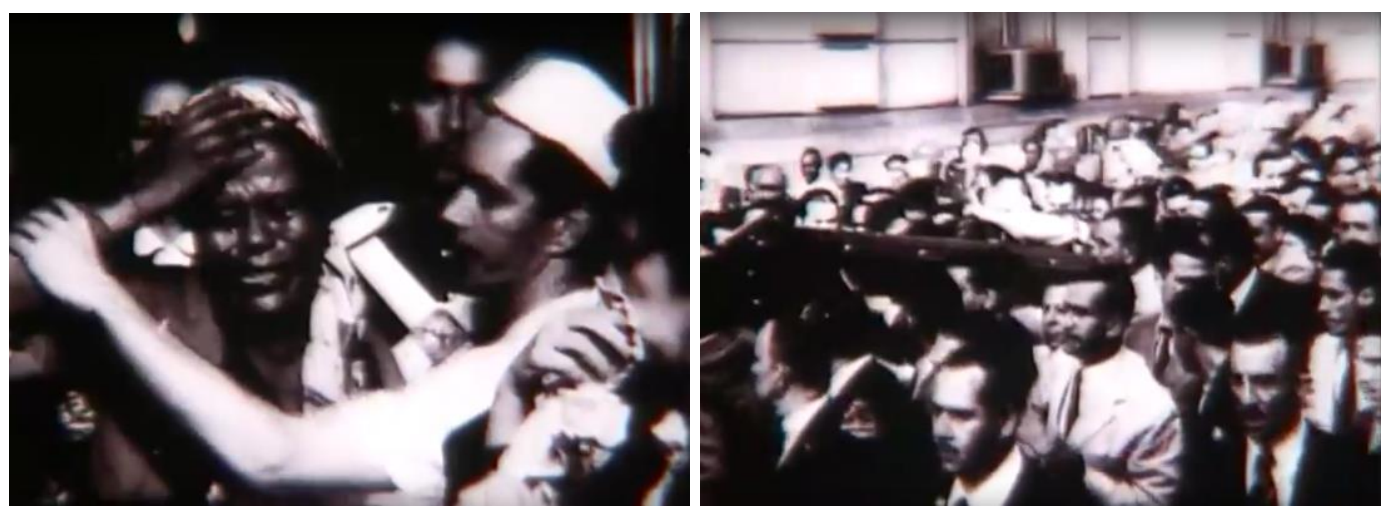

Fig.17. Glória e Drama de um Povo (1956, Alfredo Palácios).

A introdução dessas imagens em meio ao depoimento de Ulysses Guimarães só se justifica porque se articulam à outra argumentação que o filme trabalha. Trato aqui da visão operada em Céu Aberto do povo sem voz, subalterno, carente de lideranças ou, novamente, nas próprias palavras de João Batista de Andrade, “doente, buscando uma cura, uma mão santa que os pudesse livrar do mal crônico da falta de perspectiva" ${ }^{\text {71 }}$.

Dois momentos são emblemáticos de como a (ausência de) voz do povo é colocada no filme. Em uma rua movimentada, João Batista de Andrade interpela, de modo incisivo, alguns transeuntes acerca de suas impressões sobre a doença de Tancredo Neves. Nesse trecho de povo-fala ${ }^{72}$, ouvimos as mais variadas hipóteses: muitos dizem não saber o que se passava, outros começam a questionar a própria informação que lhes chegava, um rapaz ressaltava que era importante saber se Tancredo estava vivo ou morto e que as informações dos noticiários não tinham credibilidade, pois ele estava escondido. Um homem, que se coloca como pernambucano, diz que em sua terra todos estavam rezando por seu presidente que

\footnotetext{
${ }^{71}$ CAETANO, 2004, p. 330-331.

${ }^{72}$ Recurso jornalístico que consiste em entrevistar várias pessoas na rua para saber suas opiniões a respeito de determinado assunto. Esse é um dos poucos momentos no filme em que João Batista de Andrade retomava recursos expressivos dos tempos em que trabalhou na televisão. Segundo o proprio diretor, seu primeiro filme Liberdade de Imprensa já compartilhava de inquietações estéticas que o aproximaram da TV (o tom mais descontraído, a flexibilidade das ruas, a intervenção no real). Com o prestígio alcançado por Liberdade de Imprensa, João Batista embarcou na TV Cultura através do programa Hora da Notícia, espaço que lhe possibilitou produzir uma série de curtas-metragens voltados, sobretudo, para questões sociais por uma ótica de cineasta: "Eram pequenos documentários de 3, 4 e até de 7 minutos feitos num só dia por um profissional de cinema que procurava enfrentar as questões da narrativa, da CAM, do significado das palavras e das imagens num filme. Não é à toa que os filmes recuperados, Migrantes, Ônibus e Pedreira tenham se transformado em verdadeiros sucessos de distribuição [...]" (ANDRADE, 2002, p. 64). Mais à frente, João Batista trabalhou também no Globo Repórter, onde se destaca a polêmica censura envolvendo o filme Wilsinho Galileia (1977). Para maiores detalhes de sua trajetória na TV, ver ANDRADE (2002), CAETANO (2004), SACRAMENTO (2008).
} 
era a "esperança de colocar o país num rumo certo". Outro homem reitera o discurso de esperança em Tancredo e assinala que estavam passando por uma crise muito profunda no país. Um rapaz mais jovem afirmava que, sempre que alguém se voltava para o povo, os poderosos "davam um jeito desse cara sair de circulação". Segundo Rivaldo da Silva Queiróz, que havia largado sua família e trabalho no Rio de Janeiro para orar por Tancredo, este se parecia muito com seu pai e a sua morte seria uma grande perda para todos. Rivaldo aparece, em seguida, carregando uma cruz, imagem que abre uma sequência na qual a câmera perpassa uma série de pessoas em estado de transe rezando por Tancredo.
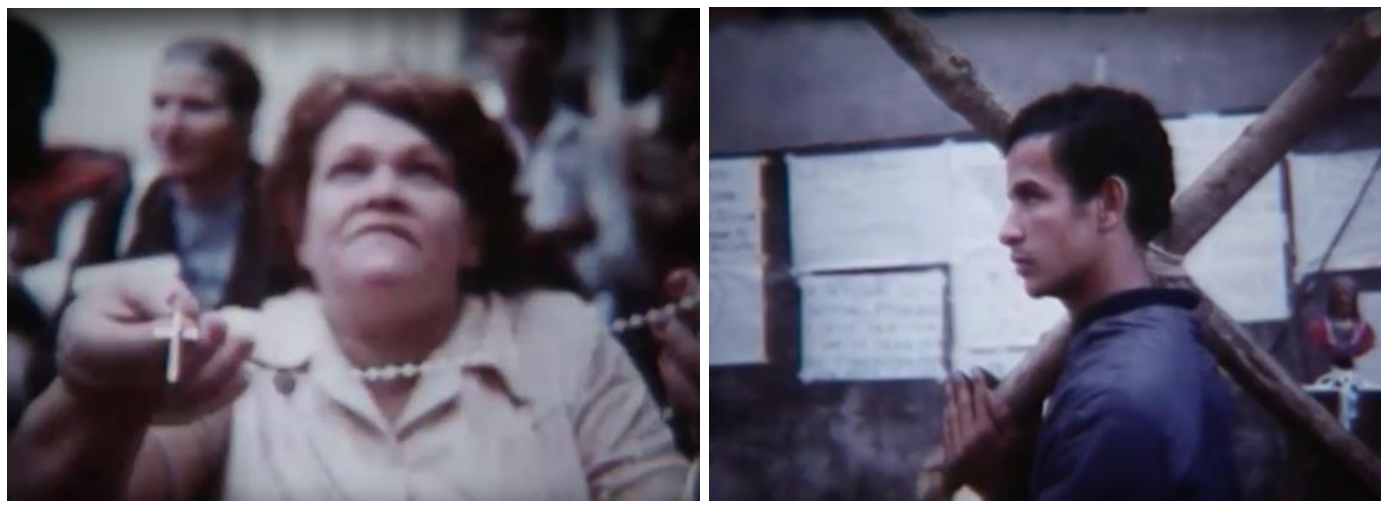

Fig.18. O transe coletivo em Céu Aberto.

Essa longa sequência, que dura quase quatro minutos, remonta a importantes filmes como Viramundo e Deus e o Diabo na Terra do Sol, os quais, a seu modo particular, expressavam a distância e o decorrente estranhamento de seus realizadores com as manifestações populares na fronteira entre o político e o religioso $^{73}$. A saída mais fácil, a mesma encontrada por Céu Aberto, era atribuir-

\footnotetext{
${ }^{73}$ Distante da visão do alienado, Maria Lucia Montes procura compreender como as manifestações religiosas se consubstanciam na dimensão política e midiática no Brasil: "[...] nossas celebrações oficiais, e portanto laicas, num Estado e num país que se querem modernos, podem de repente se transformar em festas cívicas envoltas num halo religioso, marcando momentos em que a vida social adquire um caráter sagrado, ao serem vividos intensamente no plano individual, como experiência íntima, profunda e significativa. Como no nosso catolicismo barroco arcaico, a vida dos grandes e poderosos continua a ser motivo de celebração religiosa no Brasil. Todavia, ao contrário do que ocorria nos tempos coloniais, em que se comemorava a alegria do nascimento e dos desponsórios reais, hoje é sobretudo a morte que se transfigura em motivo de festa, capaz de projetar os ritos da intimidade na vida pública e, inversamente, converter o evento social em celebração íntima da dor, que transforma o luto em festa cívica, de Getúlio Vargas e Tancredo Neves ao cantor sertanejo Leandro, da dupla Leandro e Leonardo, passando por outros heróis como Elis Regina, Ayrton Senna ou os jovens Mamonas Assassinas. É que nesses heróis mediáticos se projeta uma identificação positiva de nós mesmos, de construção tão difícil num país marcado ao longo de tantas décadas recentes pelo signo da crise - econômica, política e social -
} 
lhes as noções de alienados, ignorantes, sujeitados. É curioso perceber que, após duas décadas, o pensamento de parte da esquerda, especificamente a esquerda cinematográfica, seguia a mesma lógica dos anos 60. No contexto dos anos 80, essa lógica casava perfeitamente com a mitificação de Tancredo Neves, pois, sendo alienado e ignorante, o povo não possuía condições de tomar as rédeas do país. Carecia, portanto, de um líder político, no caso de Tancredo, ou do intelectual que falasse por eles, neste caso, o próprio cineasta através de seu filme.

Essa situação é hiperbolizada já perto do final do filme, quando o corpo de Tancredo Neves chega em Minas Gerais. Em volta do Palácio da Liberdade, vemos uma multidão apinhada tentando, de qualquer maneira, romper a barreira que os impedia de entrar no Palácio onde era velado o corpo de Tancredo. Num cenário de completa histeria coletiva, pessoas desmaiam, ferem-se nas grades pontiagudas, corpos são conduzidos sobre as cabeças amontoadas.
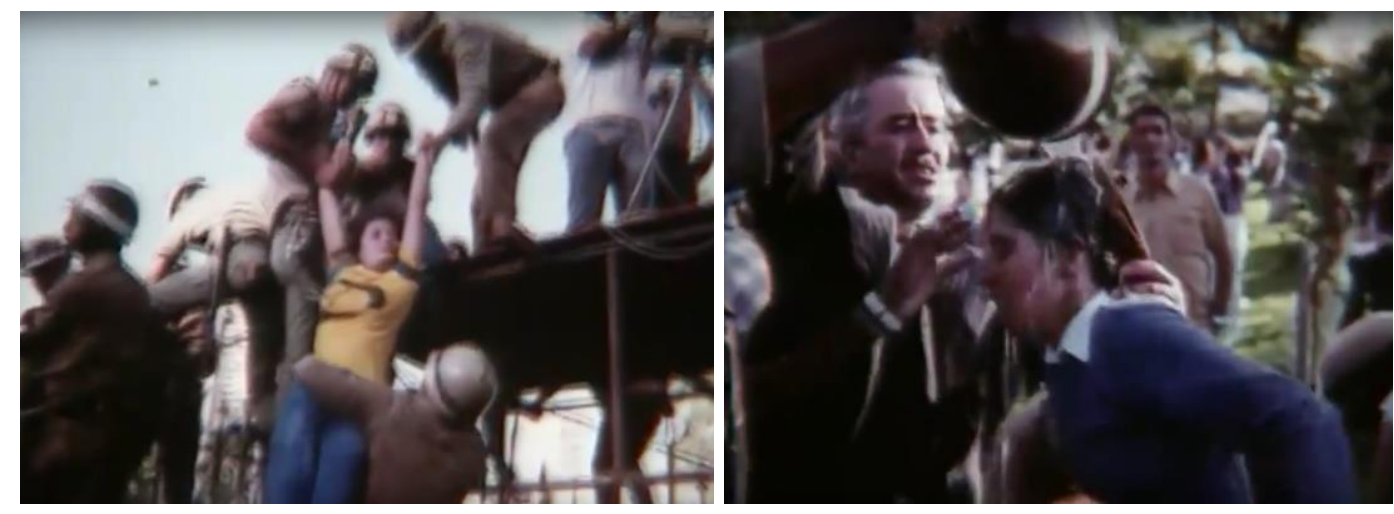

Fig.19. O desespero para adentrar o Palácio da Liberdade (MG).

É com essas imagens que aqueles arquivos do velório de Getúlio Vargas se conectam. A história brasileira se atualizava, em Céu Aberto, através dos desfechos trágicos de Getúlio e Tancredo. Atualizava-se, também, a relação paternalista de um povo que, ausente de consciência política, necessitava sempre de um um líder, um "pai”, como na fala de Rivaldo da Silva. Essa visão pode ser apreendida na forma como João Batista de Andrade percebia a configuração política no contexto de realização do filme:

"Diretas já" era um movimento de massas impressionante,

sob o qual se deu a modernização da sociedade brasileira" (MONTES, 1998, p. 164). 
unindo povo, intelectuais, políticos, mostrando sempre a cara de multidão em cada manifestação pública. E tinha uma peculiaridade sobre a qual pouco se falou, mas que está no filme Céu Aberto: o movimento revelava uma espécie de formalização de uma estrutura política civil, com seus líderes cristalizados e com funções determinadas, ou seja, levar a cabo o fim do processo de transição, tomar o poder das mãos dos militares. Não havia, na população, qualquer intuito maior, não a movia qualquer idéia de revolução, de alteração profunda na estrutura social e mesmo econômica do país. Havia a urgência de acabar com aquilo, de retomar o domínio civil sobre as estruturas do poder nacional. Ficava claro ali, como que dois pólos distintos, esferas nítidamente separadas da vida social: de um lado a esfera da política, confundida com a corporação política; de outro, o povo, mobilizado para entregar o poder aos políticos e a exigir deles o cumprimento de suas funções ${ }^{74}$.

Essa controversa compreensão do período pode ser desfeita mesmo no momento de povo-fala assinalado em Céu Aberto, no qual algumas pessoas apontam para a situação de crise e a necessidade de melhorias e mudanças. É verdade que não há um componente explicitamente revolucionário em suas falas, porém é mais que sabido que a insatisfação se expressa de acordo com a experiência coletiva e singular de cada um e, portanto, também na sua linguagem de modo específico. Soa pouco crível também que a população, sobretudo os de mais baixa renda, lutassem centralmente pela mudança política de governo militar para civil. Tanto os relatos de Céu Aberto e Linha de Montagem, quanto a historiografia ${ }^{75}$ assinalam um período de crise aguda nos anos 80 , situação que, somada à luta de determinados grupos políticos, veio a aumentar a pressão pela redemocratização do país. Ainda que se argumentasse que Céu Aberto não procura representar o povo brasileiro ou a classe trabalhadora, mas aquelas pessoas em específico, ao colocá-las exclusivamente como os membros populares de um filme repleto de figuras destacadas na política, elas resultam, inevitavelmente, como a expressão da "voz do povo" de modo genérico. Além do mais, ampliando a análise do período feita neste trabalho, podemos perceber o discurso engajado e ativo tanto nas camponesas de Terra para Rose quando da Constituinte (1988), quanto no desdobramento político do movimento sindical do ABC para o Partido dos Trabalhadores (PT). Nesse sentido, a representação que Céu Aberto nos propõe resulta limitada quanto às contradições e variedades de

\footnotetext{
${ }^{74}$ CAETANO, 2004, p. 328.

${ }^{75}$ Ver Uma história política da transição brasileira: da ditadura à democracia. (CODATO, 2005).
} 
vozes que compõem, de modo genérico, os populares, sobretudo naquele momento tão complexo.

Enquanto Terra para Rose se punha a serviço da causa camponesa e Linha de Montagem, dos operários, Céu Aberto é um filme engajado na luta pela redemocratização. Para tal, vale-se dos mais variados expedientes, inclusive desconsiderar a voz dos trabalhadores. Numa transição pactuada pelas principais lideranças políticas, feita "pelo alto" 76 , tornar o povo incapaz resultava um tanto estratégico como forma de legitimar esse processo. Esse desamparo gerado pela morte de seu líder articulado às vozes da autoridade de diversos políticos que o enalteciam, ainda que o diretor não quisesse, resultam na mitificação de Tancredo Neves como o "mártir da democracia".

Embora Céu Aberto se valha de vários recursos afinados com os discursos de sobriedade, como o uso de arquivos com fins ilustrativos e as entrevistas com caráter de enunciação direta, a sua narrativa é mais complexa que a dos filmes anteriores. A ideia de apreensão transparente daqueles eventos é perturbada sobretudo na modulação do seu espaço-tempo fílmico. A começar por não ser um filme linear: inicia-se no cortejo fúnebre de Tancredo em São Paulo, percorre os eventos de apreensão sobre seu estado de saúde e finda em seu corpo velado em Minas Gerais. A sensação que Céu Aberto promove é a de uma interrupção geral do tempo a partir da crise gerada pela enfermidade de Tancredo, sensação que pode ser materializada ao fim do filme quando ouvimos alguém dizer que a República estava praticamente imobilizada.

Além disso, algumas vezes o filme rompe com uma narrativa naturalista ao investir em recursos expressivos de montagem. Destaco uma das últimas sequências, na qual a câmera perpassa vários depoimentos de políticos destacados quando do velório de Tancredo e os abandona, um a um, em meio a suas falas. Pouco a pouco, os cortes se intensificam e se misturam ao falatório dos depoimentos, acrescido do toque incessante de um sino e da pregação dos discursos religiosos do povo, conformando uma situação caótica, própria

\footnotetext{
${ }^{76}$ Destaco, aqui, o termo "transição transada" cunhado pelo jornalista Jânio de Freitas e incorporado por Florestan Fernandes. Para este, a "abertura democrática" consistiu em uma conciliação conservadora através de uma série de medidas que combinaram repressão e consenso, reiterando a "tradição brasileira" de suprimir os setores populares dos processos decisórios no país, monopolizados pelas classes dominantes. Desse modo, a ditadura buscava institucionalizar-se, reafirmando em uma "democracia restrita" a dominação de classe que Florestan conceituou "autocracia burguesa". (FERNANDES, 2005).
} 
expressão da "República suspensa". A história surge, portanto, como incerteza. E a posse de José Sarney, ao ser filmada por trás, na qual ele próprio se viu "pesado"77, em contraste com o "bom velhinho Tancredo", apresentava-se como o próprio gesto de dar às costas ao povo, à República.

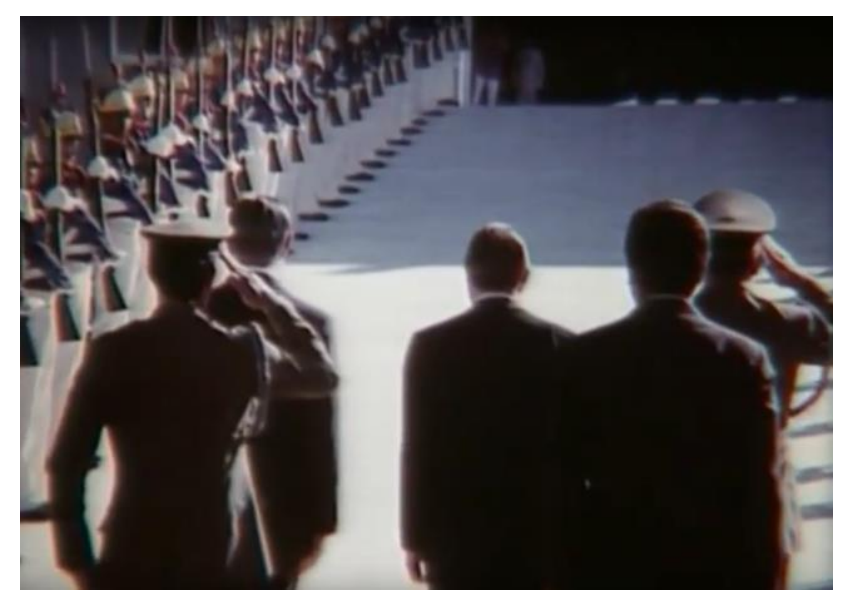

Fig.20. A posse de Sarney filmada por trás.

Desse modo, Céu Aberto se coloca um pouco diferentes que os demais filmes deste capítulo. Arquivos e depoimentos em simbiose objetiva mitificam a figura de Tancredo. Por outro lado, elementos expressivos, como a sequência acima, sensivelmente assinalam a mediação operada pelo filme e diminuem a sua impressão de objetividade, gesto muito menos presente em Terra para Rose e Linha de Montagem.

Analisando os filmes desta capítulo, fica perceptível uma importante mudança histórica. Marcelo Ridenti assinala a presença de uma estrutura de sentimento da brasilidade romântico-revolucionária entre os anos de 1950 e 1968:

Naquele contexto brasileiro, a valorização do povo não significava criar utopias anticapitalistas passadistas, mas progressistas; implicava o paradoxo de buscar no passado (as raízes populares nacionais) as bases para construir o futuro de uma revolução nacional modernizante que, ao final do processo, poderia romper as fronteiras do capitalismo ${ }^{78}$.

\footnotetext{
${ }^{77}$ Segundo João Batista, ao ver o filme José Sarney assinalou: "Nossa, meus pés parecem estar pesando uma tonelada." (CAETANO, 2004, p. 336).

${ }^{78}$ RIDENTI, 2005, p. 84.
} 
Inseridos nessa estrutura, intelectuais e artistas dos mais variados campos se puseram a contribuir na formação de uma nova sociedade, a qual pressupunha também inovações estéticas e questionamentos radicais sobre a cultura nacional. Com o golpe de 64 e a expansão da modernização conservadora, ocorre uma retração dessas ideias e os intelectuais passam a lidar de forma contraditória, por exemplo, com os investimentos estatais da Embrafilme e a sua absorção pela TV. No contexto dos anos 80, portanto, o quadro resultava bastante diferente das décadas de 50 e 60 :

[...] a sociedade havia se modernizado e urbanizado, o nacionalismo terceiro-mundista era coisa do passado, o culto ao povo cedia lugar no imaginário do PT à constituição da classe trabalhadora [...] Não havia como a estrutura de sentimento da brasilidade revolucionária expressa nas obras artísticas dos anos de 1960 permanecer" 79 .

Ridenti assinala um breve ressurgir daquela estrutura de sentimento com a campanha pelas Diretas-já, a convocação da Constituinte, a legalização dos partidos comunistas, o crescimento do PT, o Movimento Sem-Terra, porém de modo distinto dos anos 60. Contra a forma vanguardista assumida naqueles anos, procurava-se agora contribuir com a luta dos movimentos sociais por direitos e cidadania. Nesse sentido, se a estrutura dos anos 50 e 60 havia abarcado setores amplos e diversos, o que certamente possibilitou a variedade de experimentações estéticas vivenciadas no Brasil daqueles anos, no contexto dos anos 80 a atuação de artistas, em boa parte, colocou-se a serviço de lutas concretas como a dos metalúrgicos, os sem-terra e a própria redemocratização. É nesse quadro que se inscrevem os filmes deste capítulo. A transformação social deixou de ser o tema abrangente da intelectualidade e se concentrou nos artistas que se engajaram diretamente em algum movimento, os quais, como Renato Tapajós assinalou, em boa parte procuravam intervir o mínimo possível em suas representações, priorizando o didatismo da causa.

Nos filmes do capítulo 2, analiso dois documentários em que a intervenção dos diretor já esboçada em Céu Aberto são determinantes em sua composição. Filmes que, não vinculados diretamente a algum movimento social ou partido

\footnotetext{
${ }^{79}$ Ibidem, p. 102.
} 
político, ainda que inscritos nas disputas políticas da período, assinalam o desgaste dos discursos de sobriedade no documentário nacional. 


\section{O momento reflexivo}

\subsection{Diretores em cena}

Ao contrário dos filmes do capítulo anterior, por vias distintas, em Que bom te ver viva e Cabra marcado para morrer os diretores estão constantemente presentes em cena, construindo sentidos, convocando o espectador à reflexão, evidenciando que as suas asserções são produzidas no e pelo filme.

Ambos inscrevem uma das máximas bejaminianas que consiste em lutar contra uma história progressiva e hemogênea que, em sua linearidade, soterra os vencidos, suas histórias, os dissensos, as outras possibilidades de ver o mundo e a própria história. Entretanto, Que bom te ver viva e Cabra marcado para morrer fazem esse movimento não como enunciado externo, mas inserido na própria cena fílmica.

Ao se negarem a tomar os fatos de modo acabado, os dois documentários se colocam "sob o risco do real" 80 , quer pela própria encenação do filme de Lúcia Murat, quer pela constante fabulação no documentário de Eduardo Coutinho. Não por acaso, ao invés da exposição de determinado fato de forma linear e objetiva, é pela remontagem da história que a memória atravessa ambos, pois “[...] Um acontecimento vivido é finito, ou pelo menos é encerrado na esfera do vivido, ao passo que o acontecimento lembrado é sem limites, porque é apenas uma chave para tudo o que veio antes e depois" $" 81$

Nesse sentido, são documentários que produzem enunciados, asserções sobre o real, mas de forma dialética na tensão e no embate com o mundo filmado, como sínteses da articulação entre o real, filme e espectador, gesto que os coloca em outro patamar em relação aos documentários anteriores. Tampouco há a implosão desconstrutiva dos filmes do capítulo 3. Em Que bom te ver viva e Cabra marcado para morrer, prevalece uma constante oscilação entre enunciações mais objetivas da realidade e as mediações dos diretores que sucessivamente as deslocam para a dimensão subjetiva dos filmes.

\footnotetext{
${ }^{80}$ COMOLLI, 2004.

${ }^{81}$ BENJAMIN apud GAGNEBIN, 2014, p. 167.
} 


\section{2.}

\section{Que bom te ver viva: intervenção contra o silêncio}

Os últimos anos tornam Que bom te ver viva ${ }^{82}$ atualíssimo. O filme de Lúcia Murat $^{83}$, realizado em 1989 no contexto da jovem Constituição Cidadã, pode ser visto como um presságio, um aviso que diz "as coisas não vão bem, apesar da nossa vontade. Uma hora, tudo isso há de explodir”. E, de fato, passados quase 30 anos de sua realização, temos visto eclodir sucessivos discursos e práticas embasados nos anos de terrorismo de Estado praticado pela ditadura empresarialmilitar.

Marcadamente feminino, Que bom te ver viva se inscreve no contexto de afirmação de identidades, questões de gênero e étnicas, as chamadas minorias em busca de representação. Bill Nichols assinala que o século XX, ao privilegiar as lutas de caráter global, como a questão nacional ou mesmo a polarização entre capitalismo e socialismo, preteriu uma série de experiências tidas como secundárias. Foi, justamente, em meio à crise do "breve século XX", como diria Eric Hobsbawm, que uma vastidão de histórias recalcadas durante anos vieram à tona em busca de representação e a fim de expressar a singularidade de grupos historicamente marginalizados ${ }^{84}$. $\mathrm{O}$ cinema-documentário e a indexação de suas

\footnotetext{
${ }^{82}$ Que bom te ver viva teve ampla repercussão conquistando diversos prêmios, entre eles: Melhor filme e Melhor montagem; Melhor filme pelo Júri Popular; Melhor atriz para Irene Ravache Irene; Melhor fotografia para Walter Carvalho (Festival de Brasília, 1989). Prêmio Especial do Júri no Rio-cine Festival (1990, RJ).

${ }^{83}$ Lúcia Murat iniciou sua militância política na universidade e foi uma das estudantes presas no famoso Congresso da União Nacional dos Estudantes (UNE) em Ibiúna (SP). Após o Ato Institucional $\mathrm{N}^{\circ} 5$ (AI-5), entrou na clandestinidade. Militante da Dissidência Estudantil da Guanabara, posteriormente, Movimento Revolucionário 8 de Outubro (MR-8), foi presa em março de 1971, aos 22 anos, e levada ao DOI-Codi, no Rio de Janeiro. Segundo seu depoimento, foi intensamente torturada, com pau de arara, eletrochoques e espancamentos. (Memórias da Ditadura. Biografias da Resistência. Disponível em: www.memoriasdaditadura.org.br/biografiasda-resistencia/lucia-murat. Acesso em: 23/05/2018).

${ }^{84}$ A culminância desse "breve século" se deu justamente na década de 80 , com a queda do Muro de Berlim, o naufrágio da esquerda de modo generalizado, e a afirmação do modelo (neo)liberal como único horizonte de expectativa, a ponto de se proclamar o "fim da História" ${ }^{84}$ e, consequentemente, o fim das utopias. Na opaca experiência temporal que assenta o mundo contemporâneo, várias críticas foram lançadas contra os modelos epistemológicos fundados no Iluminismo que afirmavam a possibilidade de alguma objetividade no conhecimento com vias ou não à emancipação do "outro" e que, supostamente, hão fracassado. Os postulados iluministas de razão, universalidade, verdade e progresso foram pouco a pouco relegados por teorias como o pós-estruturalismo e o que tantos teóricos de modo controverso denominaram pós-modernismo, as quais declararam a cisão entre sujeito e objeto no processo de conhecimento como pressuposto idealista, e empreenderam o que se chamou de "guinada desconstrutivista". Categorias como ideologia, que em si subjaz uma ideia de falseamento da realidade e, portanto, de possibilidade de apreensão de verdade, foram cambiadas por conceitos como o discurso, de Michel Foucault, que rechaça uma verdade universal na batalha de saberes e poderes que constituem o mundo moderno.
} 
imagens com o real surgia, então, como um campo importante de abertura dos debates públicos, visibilidade de memórias reprimidas, intervenção política.

\begin{abstract}
"Nós falamos de nós para eles" adquiriu uma inflexão nova, que se propagou para diversos cantos esquecidos da vida social, da experiência das mulheres à dos afro-americanos, dos asiático-americanos, dos americanos nativos, dos latinos, dos gays e das lésbicas. Associada ao surgimento de uma "política de identidade" que honrava o orgulho e a integridade de grupos marginalizados ou excluídos, a voz do documentário deu uma forma memorável a culturas e histórias ignoradas ou reprimidas por valores e crenças dominantes na sociedade. $\mathrm{O}$ apoio às políticas governamentais ou a oposição a elas passou a ser secundário em relação à tarefa mais localizada (e, às vezes, limitada) de recuperar histórias e revelar identidades que os mitos, ou as ideologias, da unidade nacional negaram ${ }^{85}$.
\end{abstract}

Nesse sentido, pulularam documentários que buscaram abarcar a multiplicidade de experiências através de entrevistas e depoimentos, dado que este recurso mantinha a enunciação do discurso direto, porém ampliava a voz do filme. Que bom te ver viva é um deles, entretanto, articulando outros recursos formais junto aos depoimentos, constitui-se um documentário marcadamente híbrido. Tal qual Terra para Rose, o eixo de sua abordagem também são as mulheres de forma coletiva, porém, ao compartilhar as memórias das sobreviventes da repressão sistemática praticada pela ditadura, o estrato social abarcado no filme de Murat resulta predominantemente de classe média. Lúcia Murat, também ex-guerrilheira e também torturada nos porões da ditadura, realizou um filme também sobre si.

Que bom te ver viva se estrutura basicamente através da articulação de relatos das ex-guerrilheiras torturadas ${ }^{86}$, de alguns familiares e pessoas próximas, e uma série de monólogos realizados pela atriz Irene Ravache. Frente à câmera, suas intervenções condensam as experiências das demais sobreviventes e agem no

Foi esse contexto que levou as Ciências Sociais a se abrirem para novas perspectivas de análise. Passou-se a valorizar o precário, o que sobrevive, o que se situa às margens e escapa às generalizações, proporcionando questionamentos de alteridade em torno da representação de inúmeros grupos silenciados, subalternizados ou tratados, até então, de forma estatística. Conforme Foucault assinalou em Microfísica do Poder, todo saber é uma manifestação de poder e, dessa forma, na conjuntura histórica que observamos, a voz unívoca e onisciente dos documentários clássicos não mais era aceita como legítima a apreender e transmitir a dinâmica social que novos agentes reivindicavam.

${ }^{85}$ NICHOLS, 2005 a, p. 193.

${ }^{86}$ Em ordem de aparição no filme: Maria do Carmo Brito, Estrela Bohadana, Maria Luiza G. Rosa (Pupi), Rosalinda Santa Cruz, ex-guerrilheira não identificada, Criméia de Almeida, Regina Toscano, Jessie Jane. 
sentido da quebra da quarta parede brechtiana. Esse recurso traz o espectador de forma política para a cena, rechaçando uma possível catarse anestésica. O próprio tom e cenário que envolvem as passagens de Irene Ravache no filme acentuam uma intervenção teatralizada marcadamente política.

Destaco a sequência em que a atriz lê uma matéria de jornal, na qual se questionava se era a hora de seguir publicando livros sobre as prisões dos anos 70 . Ravache interrompe a leitura, vira-se para a câmera e questiona quem é que pode saber a hora de voltar ao tema. Sua argumentação, entre indignação e ironia, revela o choque de temporalidades que o fim dos anos 80 e a redemocratização traziam ao Brasil:

Qual é a hora? Isso aqui parece letra do Vandré, tão década de 60. E o cara que assina a matéria é do tipo novaiorquino. Ele acha out falar em torturas, prisões. Claro, porque ele é moderno. Aliás, ele é pós-moderno. E agora ele vem me falar em hora. Quer dizer, eu tenho que me lembrar na hora que ele determinar. Babaca.

Através desse trecho, podemos apreender aspectos da atmosfera cultural e política que permeava o período. Enquanto a geração de Lúcia Murat seguia vasculhando os escombros de um passado traumático e não findo, surgiam novos agentes que, não tendo vivido os "anos de chumbo", miravam o futuro e a integração do país com o mundo moderno. Nas palavras da própria diretora:

[...] todos os meus filmes sempre foram movidos por fatos que aconteceram no presente e me fizeram tratar do passado. Eles não começavam no passado, eles estavam respondendo a questões do presente - até porque o passado continua presente, o passado não morre ${ }^{87}$.

Desse modo, Que bom te ver viva se voltava à atualidade daquelas mulheres que foram torturadas, às dificuldades que tinham de lidar no presente por conta do seu passado. Os monólogos de Ravache materializavam, de forma lúdica e eminentemente política, suas experiências pessoais, como na sequência em que a atriz lamenta o sumiço de seu amante. Em sua explanação, credita o fato à matéria de jornal que havia saído sobre as torturas que sofrera e reclama de sua transformação em mártir:

87 “E agora, Lúcia?”, Filme Cultura, 60, julho/agosto/setembro 2013. 
Acha que não vai mais conseguir trepar comigo, porque com mártir não se trepa. É Nossa Senhora, Joana D'arc, quem é que trepa com Joana D'arc? [...] Não dá pra pensar que é humano, que tem vontade, que faz cocô, que tem tesão... Quem sobreviveu não é humano. Igual ao torturador, que também não é. Ô merda, o pior é que eu também acho isso...

Até então, essa sequência respeitava os códigos de uma representação naturalista como se Ravache dialogasse consigo mesma. É apenas quando trata do torturador que a atriz se vira para a câmera e profere de forma incisiva: "Todos vocês acham que a gente é diferente, só pra fingir que nunca vão estar no lugar da gente”. Este momento é seguido de uma explanação exaltada na qual Ravache brada por "uma forca pra cada um de nós em praça pública". A atriz, então, dá um gole numa bebida, vira-se para a câmera novamente e diz "Pode parar, pode parar. Guardem a minha pra quando eu tiver 80 anos. Essa é a minha história e vocês vão ter que me suportar".

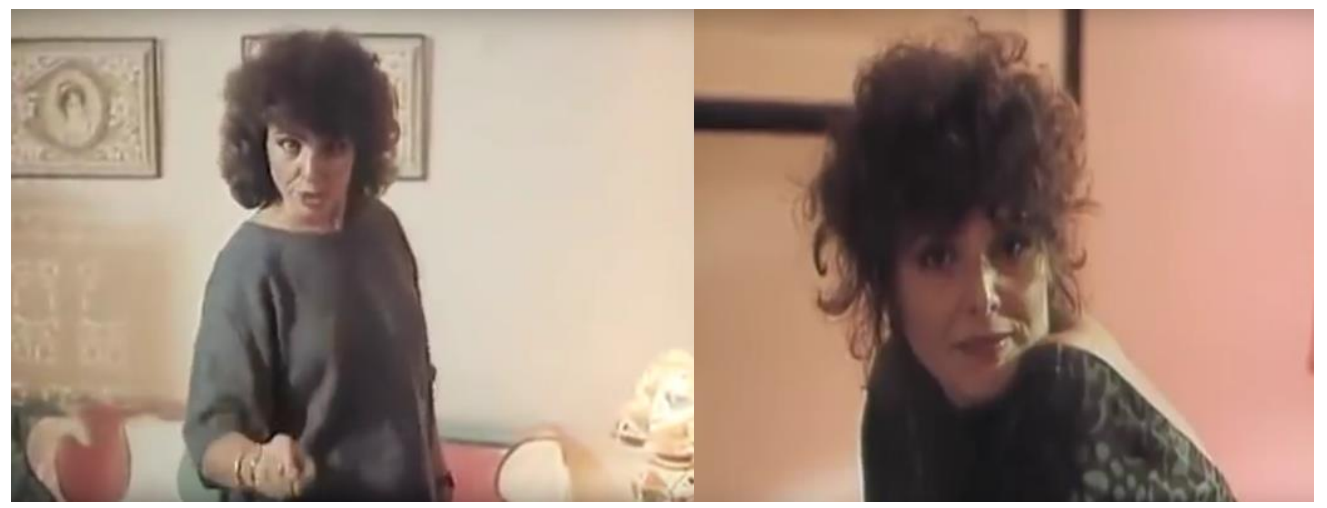

Fig.21. Irene Ravache se dirige ao espectador em Que bom te ver viva.

Na gênese do cinema, foram estabelecidos uma série de parâmetros diegéticos com vistas à elaboração de uma narrativa naturalista. Entre eles, estava o rechaço do gesto de se dirigir diretamente à câmera característico de vários filmes de finais do século XIX, denominados “cinema de atrações” por Tom Gunning.

Tom Gunning usa o termo "cinema de atrações" para caracterizar este primeiro período, povoado por filmes exibicionistas, que não chegam a narrar, mas simplesmente mostram alguma coisa excitante. Ao contrário do cinema que vai se desenvolver na década seguinte e que procura esconder seus artifícios para criar um mundo fictício orgânico (a diegese) o primeiro cinema funciona como um palco de variedades, 
promovendo uma integração permanente entre a tela e a platéia, através do enquadramento frontal e da interpelação direta que os personagens dirigem ao público, por meio de acenos, piscadelas e sorrisos ${ }^{88}$.

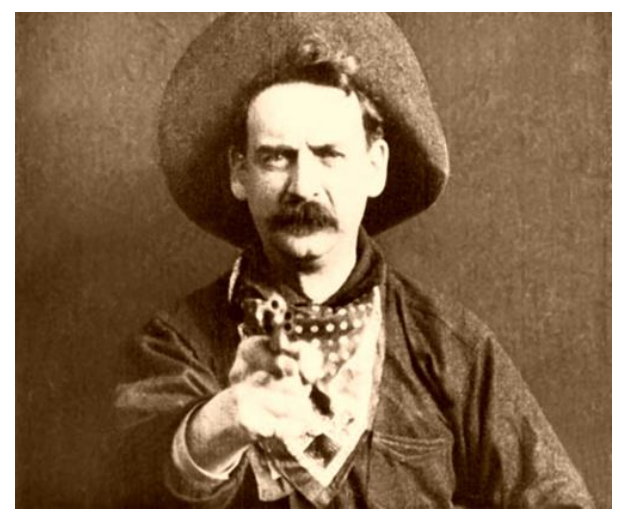

Fig.22. O Grande Roubo de Trem (1903, Edwin Porter).

Rompendo com a diegese naturalista e, por conseguinte, com a objetividade plena do filme, a interpelação direta de Ravache à câmera operava uma desestabilização central dos discursos de sobriedade. Em Que bom te ver viva, o espectador não tem escapatória frente à atriz que sucessivamente o convoca à cena. E, assim, a ditadura, suas sequelas e as decorrentes memórias traumáticas, são devolvidas às parcelas da sociedade que haviam optado por "tapar o sol com a peneira”, conforme podemos observar no conteúdo de suas falas, que perpassam a responsabilização da violência praticada e a necessidade de se falar sobre.

A interrupção catártica realizada por Ravache se conjuga com o sentido da montagem do filme. Que bom te ver viva evita a retórica fácil, o melodrama que pasteuriza os dramas reais. Ao contrário da mídia hegemônica que investe na espetacularização dos momentos de maior emoção, no filme de Murat, ou eles surgem de forma natural e não assumem preponderância notável sobre os demais temas e sentimentos ou são brecados na própria montagem. Como exemplo, cito a sequência na qual Regina Toscano relata como ocorreu sua prisão. Após contar que fora presa em uma panfletagem e que a violência já havia começado ali mesmo, Regina lança a seguinte frase: "E a partir dali fui pro DOI-Codi". Neste momento, a entrevistada parece reviver em frações de segundo o passado doloroso que carregava. Regina suspende sua narração, cerra os olhos e no momento em

\footnotetext{
${ }^{88}$ DA-RIN, 2004, p. 31.
} 
que leva a mão esquerda ao rosto esboçando o choro que viria, o filme congela sua imagem que, pouco a pouco, desaparece da tela através de uma suave fusão.
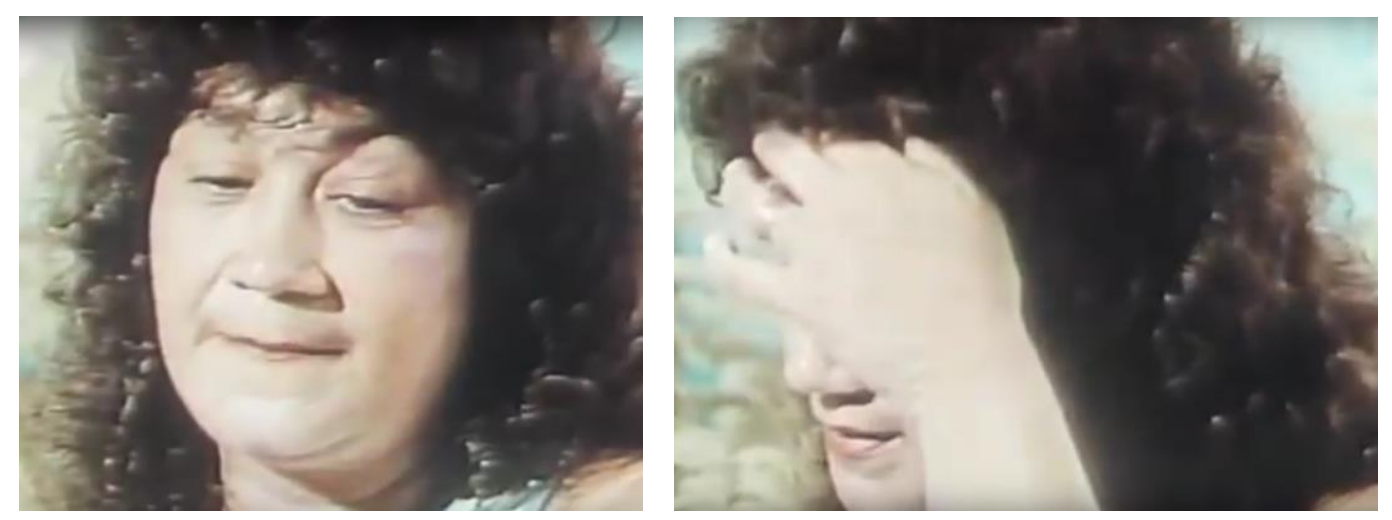

Fig.23. O relato emocionado de Regina Toscano.

Essa é uma forma sensível de apontar lacunas, silenciamentos e reflexões através de recursos de montagem. Outros mecanismos também são utilizados como forma de perturbar as vozes das depoentes e sua apreensão imediata: inserções de sons extradiegéticos, quebras bruscas dos depoimentos através de fades, imagens com caráter marcadamente simbólico, como a recorrente imagem da fechadura de uma cadeia. Estes elementos constituem artifícios secundários que, a depender do contexto, podem adensar os relatos, enfatizar determinado aspecto ou mesmo interromper algum sentido. É preciso mencionar também que, entre as encenações da atriz e as passagens das depoentes, são inseridos alguns arquivos, sobretudo jornais da época da ditadura. Estes se colocam no que poderíamos chamar de lado objetivo do filme, pois não passam por nenhuma tensão estética, cumprindo o papel de atestação histórica do passado.

Ao contrário de todos os filmes vistos até aqui, os relatos em Que bom te ver viva não são tomadas sem problematização, como mera confirmação da experiência das depoentes. Ora reflexivos e críticos, ora dialógicos e sintéticos com as entrevistadas, a narração do filme constantemente incide sobre os relatos, mantendo um certo ceticismo e demarcando sua independência em relação às demais vozes do documentário. No primeiro relato do filme, Maria do Carmo Brito detalha que, após a morte de seu companheiro pela repressão, passou por um longo processo de reconciliação consigo mesma que culminou com sua gravidez. 
Em seguida, vemos imagens de seu cotidiano em casa e ouvimos o seguinte texto em off:

Observando do lado de fora, como um voyeur olha pela janela da vizinha, meu olhar é igual ao de todo mundo. E a história de Maria, hoje, uma educadora que é casada e tem dois filhos parece não ter muito a ver com esse passado. Na maternidade, Maria diz ter resgatado a possibilidade de vida, mas isto explica ou encerra tudo?

O tom proposto por essa ponderação invariavelmente desloca Que bom te ver viva de uma adesão plena aos depoimentos. Junto aos monólogos de Irene Ravache, esses comentários são formas de preservar o filme como um agente que constrói seus significados através do diálogo, das reflexões, da própria provocação ao espectador. Essa situação pode ser percebida de forma mais aguda em meio ao depoimento de Regina Toscano, quando esta relata que os torturadores se aproveitavam da sua condição de epilética para degradá-la. Após o filme escapar mais uma vez do momento de choro que viria, vemos imagens de Regina em um restaurante com uma amiga e ouvimos:

E o nosso quebra-cabeças fica de novo difícil de montar. Como encaixar este sorriso de Regina, que parece se abrir para o mundo, com a lembrança que durante toda a entrevista o remédio contra a epilepsia estava ao lado? O medo de não aguentar fez com que ela se preparasse para o pior num ritual que só ela conhece [...].

Esse trecho é particularmente relevante, pois congrega o tom reflexivo de outros trechos a um meta-comentário apresentando as condições em que se deram as filmagens. Apesar de comentar sobre as personagens na terceira pessoa, a voz da diretora se coloca também em cena e, portanto, uma possível exteriorização objetivista é logo afastada da narrativa.

Bill Nichols assinala esse tipo de postura assumida por Lúcia Murat em Que bom te ver viva como formas documentais mais sofisticadas de não deslocar simplesmente a autoridade da narração onisciente para as entrevistas ${ }^{89}$. O filme

\footnotetext{
89 “A entrevista ainda é um problema. Subjetividade, consciência, forma argumentativa e voz continuam inquestionadas na teoria e na prática do documentário. Muitas vezes os cineastas simplesmente decidem entrevistar personagens com os quais concordam. Prevalece um fraco senso de ceticismo e pouca autoconsciência do cineasta como produtor de significado ou história, gerando um senso mais uniforme e menos dialético de história e um senso mais simples e mais
} 
produz asserções, mas estas surgem como síntese dialética da interação entre diretora, depoentes e espectadores que são convocados a refletir, e não apenas a constatar determinado argumento, como prevalece nos filmes do capítulo 1. A própria diretora explicita sua distância estético-política em relação àqueles documentários:

[...] eu tenho alguma resistência contra essa expressão "cinema político", porque primeiro vira um clichê e depois se torna depreciativo. Aí acaba virando sinônimo de um cinema panfletário, de mensagens - e eu não me vejo assim, não me interessa fazer proselitismo ${ }^{90}$.

Distante de um tipo de cinema que se presta a emitir mensagens políticas, distante dos discursos de sobriedade. A lógica da informação jornalística acabada, sem brechas, é debochada em uma das intervenções de Ravache. Em analogia à pretensa imparcialidade com que uma revista a identificara como terrorista, e o torturador como médico, a atriz encena uma paródia do telejornalismo padrão sobre o Caso Mengele, no qual as imagens e o conteúdo transmitidos são revolvidos de tom imparcial e sóbrio com fins de conferir legitimidade à informação. Reafirmava-se, através da teatralização (parte mais densa do filme), o rechaço à realidade enquanto um dado plenamente apreensível.

Embora a narrativa de Que bom te ver viva não estabeleça uma linearidade causa-efeito, detendo-se na persistência do trauma e de todas as dificuldades que as ex-guerrilheiras torturadas carregam, o argumento do filme ruma para a sua redenção. Em uma divagação sobre o torturador, Ravache recorda que era chamada por ele de "cachorrinho de Pavlov". Em seguida, ironiza que, ao contrário dos tempos da ditadura, no fim dos anos 80 as torturadas ocupavam uma posição de maior destaque na sociedade que "o torturador", o qual vivia acuado e escondido. Ravache, então, dialoga diretamente com a câmera como se fosse o próprio torturador:

[...] eu acho pouco. tinha te prometido um julgamento, mas o nosso Brasil brasileiro não gosta muito dessas coisas. Ficamos apenas com as nossas pequenas vinganças. Mas, diga-me, o que a sua mulher achou quando leu no jornal que você andou

idealizado do personagem. Os personagens ameaçam emergir como astros-chamas de inspiradora e imaginária coerência, contraditória com sua aparente condição de pessoas comuns" (NICHOLS, 2005a, p. 62).

90 “E agora, Lúcia?”, Filme Cultura, 60, julho/agosto/setembro 2013. 
fazendo tortura sexual? E o que você achou quando eu dei aquela fantástica entrevista na televisão falando sobre o meu último trabalho? Pode ser que o seu cachorrinho de Pavlov vá passar o resto da vida levando choque, mas ele venceu.

Esse trecho é bastante importante, dado que condensa tanto a superação das ex-guerrilheiras quanto os impasses políticos sobre a punição dos torturadores. De forma indireta, suscitando reflexões, o filme se coloca nos debates públicos sobre a memória do período ditatorial.

A narrativa da redenção é retomada de forma mais incisiva no final do filme. Após haver escavado todas aquelas memórias dolorosas, vemos imagens (em geral, felizes) do cotidiano das entrevistadas junto a curtos relatos finais que perpassam a necessidade de prosseguir suas vidas, seu gesto de superação e a persistência da luta política. Destaco os seguintes trechos: Estrela Bohadana: "Eu acho que, pra mim, a maior vitória é essa busca, é esse desejo de me reintegrar internamente, juntar os meus pedacinhos internos"; Puppi: "A minha relação com a política continua a mesma. Eu continuo, até hoje, achando que vale a pena você lutar pra transformar o mundo num mundo melhor. Embora eu enxergue que o mundo que a gente vive hoje não tem os ideais que eu achava que tinha"; Criméia de Almeida: "Eu persisto na cobrança, eu continuo cobrando, eu não fiz parte desse acordo de silêncio". O relato firme e conclusivo de Regina Toscano, não por acaso, encerra esta longa sequência de afirmação daquelas mulheres:

O que eu sinto, talvez eu esteja me superestimando, mas eu acho que eu sou muito mais forte do que os caras. Eu passei um momento onde eles eram numericamente muito superiores a mim, mas eu acho que, em termos de pessoa, de ser gente, de sentimento, eu me sinto mais forte que eles. Eu acho que, hoje em dia, eu posso falar que tive vitórias. $E$ acho que eles não podem falar isso. Acho que eles tiveram derrotas, derrotas pessoais. Eu me sinto superior, não é negócio de medir força com torturador. Não sou eu, nós somos bem acima deles. 

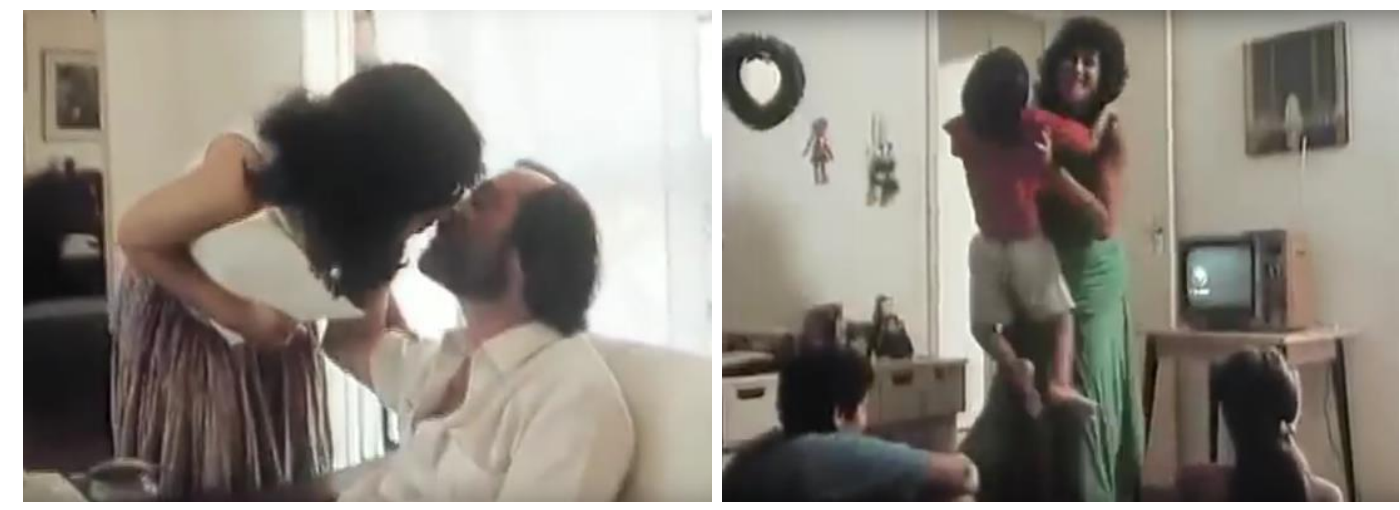

Fig.24. A superação das personagens de Que bom te ver viva.

Nessa sequência, não há questionamentos ou reflexões da narração do filme, pois, conforme o trecho de Ravache sobre o "cachorrinho de Pavlov" sinaliza, é também uma redenção da própria diretora. Ao contrário dos filmes do capítulo 1 , em Que bom te ver viva, a diretora faz parte da cena e do mesmo drama experimentado pelas várias vozes que o compõem. Neste momento, portanto, Lúcia Murat afirma, junto e através das outras mulheres, o seu gesto coletivo de superação. Estas acabam por antecipar um novo "tipo social". Ao falarem exclusivamente de suas vivências e memórias enquanto mulheres que foram torturadas, as vozes das entrevistadas, em consonância com a voz do filme, generalizam essa experiência em um novo "personagem" que o cinema trataria largamente nos anos $90^{91}$ : o torturado ou o preso político. Para ser mais preciso, a torturada.

Dialogando com todos esses depoimentos em seu transcorrer, a política do filme de Lúcia Murat se direciona às narrativas oficiais que se fundam no apagamento dos lutas sociais e dos arbítrios cometidos. Age, assim, no sentido de trazer à tona as "memórias subterrâneas" apontadas por Michael Pollak, as quais “[...] prosseguem seu trabalho de subversão no silêncio e de maneira quase imperceptível afloram em momentos de crise em sobressaltos bruscos e exacerbados. A memória entra em disputa." ${ }^{92} \mathrm{O}$ momento de crise é, justamente, o contexto da transição e os debates aflorados que a Constituinte trouxe para a sociedade brasileira.

\footnotetext{
${ }^{91}$ Através de um precioso levantamento feito por Caroline Gomes Leme (2011), em sua dissertação Cinema e sociedade: sobre a ditadura militar no Brasil, a partir dos anos 90 é perceptível um verdadeiro boom da temática da guerrilha urbana e a decorrente questão da tortura. ${ }_{92}$ POLLAK, 1989, p. 4.
} 
Nesse sentido, é marcante a sequência em que uma moradora da Baixada Fluminense colocava suas impressões sobre a tortura ocorrida nos tempos da ditadura: "Isso não me choca, porque a violência na Baixada Fluminense é maior que uma tortura política. A 500 metros daqui, há um ponto de desova e os nossos filhos convivem com isso no dia-a-dia. Não é dizer que não choque a gente, mas amortece". Segundo dados de 2015 da Anistia Internacional ${ }^{93}$, a polícia brasileira é a que mais mata no mundo, incorrendo em inúmeros casos de arbítrios, torturas, execuções, desaparecimentos, agora direcionados à população negra e favelada. Jeanne Marie-Gagnebin atenta que por não ter elaborado, efetivamente, o trabalho de luto e "sepultamento" 94 sobre o que significou a ditadura, vivemos um presente de constante atualização daqueles anos na permanência da tortura contra o setores mais pobres da sociedade. Sendo assim, a batalha pela memória travada pelos torturados, bem como por filhos ou amigos de desaparecidos, é também uma luta que perpassa a atualização das estruturas de repressão no país.

É interessante notar que nas sequências de afirmação das ex-guerrilheiras e sobre a violência na Baixada Fluminense, Que bom te ver viva prima pela não intervenção, assumindo aqueles discursos para si. Decorre, então, uma construção fílmica situada em uma constante dialética entre a objetividade dos relatos e a subjetividade da diretora. Os comentários e as intervenções de Ravache cumprem o papel de explicitar o documentário como um agente produtor de sentidos, o que poderia ser comprometido caso o filme nos mostrasse apenas os depoimentos das personagens e os arquivos como provas do passado. Em Sob o Risco do Real ${ }^{95}$, Jean-Louis Comolli postula o documentário como o lugar da não-roteirização ficcional, das ambiguidades, das aberturas contra os fatos acabados. Ironicamente, no documentário de Lúcia Murat é justamente a dimensão ficcional e roteirizada que desestabiliza a impressão de objetividade da sua parte documental. Já Cabra marcado parar morrer, próximo documentário analisado, é exemplar do gesto

\footnotetext{
${ }^{93}$ Amnesty International releases new guide to curb excessive use of force by police. (Disponível em: www.amnesty.org/en/latest/news/2015/09/amnesty-international-releases-new-guide-to-curbexcessive-use-of-force-by-police. Acesso em: 07/03/2018).

${ }^{94}$ Paul Ricoeur assinala a importância do ato de sepultamento como forma de liberar o passado recalcado: "[...] a operação histórica por inteiro pode então ser considerada como um ato de sepultamento. Não um lugar, um cemitério, simples depósito de ossadas, mas um ato renovado de sepultamento. Essa sepultura escriturária prolonga no plano da história o trabalho de memória e o trabalho de luto. $\mathrm{O}$ trabalho de luto separa definitivamente o passado do presente e abre espaço ao futuro" (RICOEUR, 2007, p. 504).

${ }^{95}$ COMOLLI, 2004.
} 
defendido por Comolli. É no real gerado e filmado por Eduardo Coutinho que tudo ocorre, não cabendo ali as roteirizações e as significações externas à cena.

\section{3. \\ O desdobramento do real: sobre Cabra marcado para morrer}

Filme de extrema relevância e repercussão, Cabra marcado parar morrer representa um momento de síntese e viragem para as realizações que viriam a seguir $^{96}$. O documentátio de Eduardo Coutinho é um marco fundamental no deslocamento dos discursos de sobriedade no documentário nacional. Pois, se eles "consideram sua relação com o real direta, imediata, transparente" tom sóbrio, Cabra marcado para morrer afasta-se um tanto dessa órbita ao priorizar o traço reflexivo em sua linguagem e a imprevisibilidade dos encontros às certezas e encadeamentos factuais em sua construção.

A história é bastante conhecida e não faltam detalhes ${ }^{98}$. Todo o processo de elaboração do filme, a fuga, as prisões e a procura do filmagens, estão detalhados em uma narração em off logo em seu começo e nas conversas com os camponeses em seu transcorrer. Esse é um primeiro aspecto a ser assinalado. Embora o documentário de Eduardo Coutinho lance mão da narração em voz off, esta não vem exclusivamente a explicar algo. No Cabra, há dois narradores: o poeta Ferreira Gullar e o próprio Coutinho. Cabe ao primeiro a função objetiva do filme, situando a parte histórica sobre as Ligas Camponesas, o engenho Galiléia, João Pedro e Elizabeth Teixeira, bem como os demais personagens. Já Coutinho, em primeira pessoa, narra sua experiência pessoal que engendrou o documentário, propondo um tom reflexivo em constante diálogo com o espectador e interagindo com as pessoas que encontra no filme.

No começo do Cabra, há uma sequência importante que ilustra a tessitura de vozes que o filme aplica. Após um plano da preparação da exibição das antigas filmagens para os camponeses, vemos alguns planos-gerais do engenho Galiléia e ouvimos o seguinte texto narrado por Coutinho:

\footnotetext{
${ }^{96}$ Cabra marcado para morrer foi eleito pela Associação Brasileira de Críticos de Cinema (Abraccine) o melhor documentário do cinema nacional. Seu alcance pode ser mensurado, por exemplo, no filme $O$ Som ao Redor (Kleber Mendonça Filho, 2013). Possivelmente a obra mais destacada da cinematografia brasileira contemporânea, em seu prólogo assistimos a uma série de fotografias extraídas do Cabra.

${ }^{97}$ NICHOLS, 1997, p. 32 (tradução nossa).

${ }^{98}$ Destaco o precioso relato Pequena memória do Cabra, de Vladimir Carvalho (OHATA, 2013).
} 
Fevereiro de 1981, 17 anos depois voltei à Galileia para completar o filme do modo que fosse possível. Não havia um roteiro prévio, mas apenas a ideia de tentar reencontrar os camponeses que tinham trabalhado em Cabra marcado para morrer. Queria retomar nosso contato através de depoimentos sobre o passado, incluindo os fatos ligados à experiência da filmagem interrompida, a história real da vida de João Pedro, a luta de Sapé, a luta de Galileia, e também a trajetória de cada um dos participantes do filme daquela época até hoje.

Esse recurso, que se tornaria frequente em seus filmes, marca a vinculação de Coutinho com os pressupostos do Cinema Verdade. Em detrimento de qualquer enunciação exterior, o que lhe importa é filmar a situação gerada pela presença da equipe cinematográfica. Portanto, de antemão, Coutinho nos apresenta os princípios norteadores de seu filme. Em seguida, é a voz de Ferreira Gullar que apresenta os únicos homens ainda vivos que iniciaram a luta de Galiléia nos tempos das Ligas Camponesas: José Hortêncio da Cruz e João Virgínio Silva. Este último explica minuciosamente como se deu a primeira reunião do grupo de camponeses que viriam a se organizar politicamente. Seu relato é alternado com a narração impessoal de Gullar característico da tradição documental clássica, como no texto a seguir:

Galiléia era um engenho de fogo morto dividido em pequenas parcelas de terra. Nela, viviam 150 famílias de foreiros, que cultivavam lavoura de subsistência. $\mathrm{O}$ dono do engenho morava em Recife. Os foreiros pagavam aluguel anual, o foro. O aumento do foro foi também uma das causas da fundação da Liga.

Em seguida, João Virgínio segue explicando as nuances da criação das Ligas Camponesas, cumprindo o papel, nesse momento, de locutor auxiliar da contextualização histórica operada no filme. Toda essa sequência é permeada por uma série de imagens de arquivo: a antiga Galiléia, camponeses trabalhando no roçado, mulheres preparando a comida, jornais da época sobre o conflito, com destaque para a presença de Francisco Julião, advogado e líder das Ligas, figura marcante das lutas sociais dos anos 60. São imagens atestatórias em sintonia com a objetividade do texto narrado por Gullar e da rememoração de João Virgínio. 

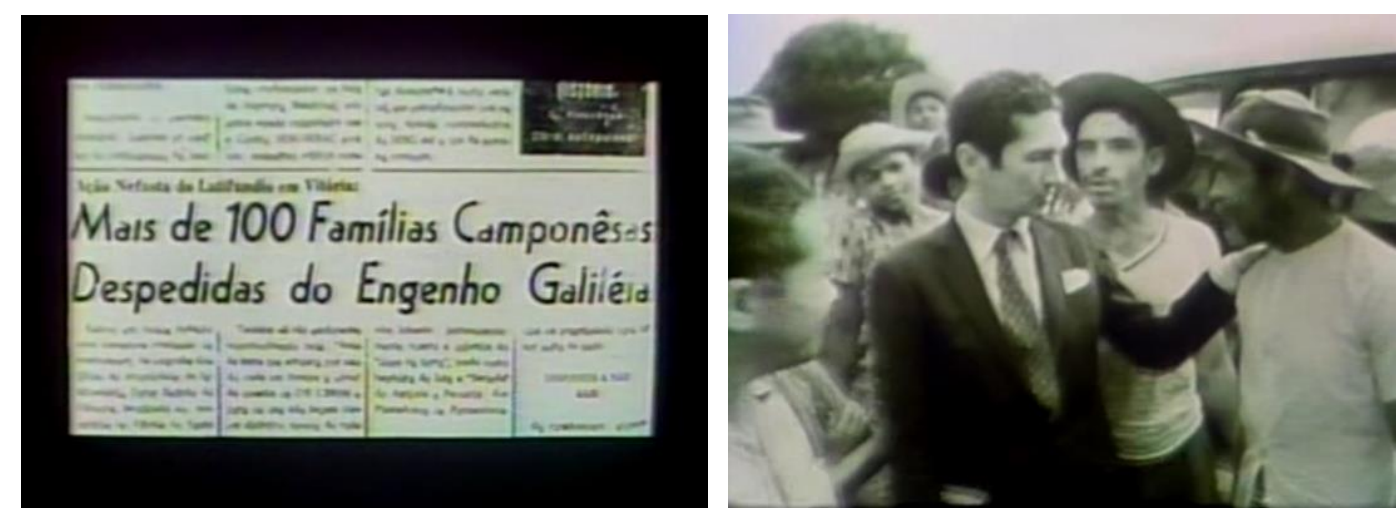

Fig.25. Os arquivos reconstróem o passado em Cabra marcado para morrer.

Ao articular o imbricamento de vários regimes de vozes, entre todos os filmes que analiso neste trabalho, o Cabra é o que expressa uma voz mais complexa. O filme é a síntese do diário de viagem de Coutinho, "do modo que fosse possível", em busca dos personagens das filmagens de 64. Esse é um elemento que o coloca em outro patamar. Não se trata do registro da vida daquelas pessoas, mas o registro do encontro de Coutinho com elas. A realidade, portanto, não surge como um dado previamente estabelecido ou objetivamente capturada pela câmera, rompendo com a crença de que o filme captura algo imutável que ocorreria do mesmo modo sem a sua presença.

Um dos momentos-chave sobre o modo como o filme opera intervindo no real e registrando suas modulações ocorre no encontro de Coutinho com Elizabeth Teixeira. Abrindo essa sequência, mais uma vez, ouvimos as duas locuções articulando seus tons. Inicialmente, é a voz de Gullar que nos informa que Elizabeth estava desaparecida há 17 anos e que seu filho Abraão era o único que sabia de seu paradeiro. Em seguida, Coutinho nos conta como se deu o processo de negociação com Abraão e detalha o trajeto percorrido. Ao vermos as imagens do encontro, Coutinho conclui seu relato de viagem informando que Elizabeth não esperava a sua chegada e que começou a sua conversa exibindo as 8 fotografias de cena das antigas filmagens que havia recuperado. Elizabeth se mostra surpresa com as fotos e pergunta como Coutinho conseguiu recuperá-las. Após a explicação do diretor, ela diz: "Eu admiro...."

Nesse primeiro dia de encontro, junto a seu filho Abraão, vemos Elizabeth retraída, constrangida, referendando as palavras desajeitadas de seu filho, com as 
quais elogiava o "presidente Figueiredo"99. Em seu relato, Elizabeth diz que não imaginava reecontrar Coutinho e que já havia perdido as esperanças de retomar sua vida e reencontrar seus filhos: “[...] quando cheguei aqui, ninguém sabia quem eu era. Hoje, como vocês estão aqui, o pessoal tudo tá sabendo...”. Na noite desse mesmo dia, Coutinho exibiu as filmagens dos anos 60 para Elizabeth e seus filhos. Esse gesto parece provocar uma verdadeira metamorfose em Elizabeth, que, ao se ver na tela, divertiu-se bastante e procurou reconhecer as pessoas nas imagens.

Já no segundo dia, sem a presença de Abraão, Elizabeth recebeu Coutinho e os membros da equipe de fimagem da janela de sua casa. Com um sorriso marcante no rosto, colocava-se um tanto mais solta:

[...] ontem à noite eu fiquei imaginando... Na entrevista, eu falei muito mal. Eu fiquei muito emocionada [...] Porque eu devia ter começado direitinho, a vida, como você queria, de início, como nós começamos o namoro, depois casamos, fomos morar em Jaboatão. Se você deixasse pra hoje, eu tinha me expressado melhor $[\ldots]$.

Essa fala de Elizabeth é preciosa sobre a construção do filme. Ante uma realidade que transbordara cheia de lacunas e hesitações por conta da sua chegada, Coutinho não a rejeita em prol de uma coerência narrativa. A voz de Cabra marcado para morrer se constrói justamente na constante mutação que as vozes dos entrevistados articulam. A figura de Elizabeth ganha muito mais força quando percebemos a transformação que as imagens operaram sobre ela.

Nesse sentido, embora haja uma narração impessoal a apresentar os fatos, pouco a pouco, a voz do diretor e dos personagens ganham relevo através de suas memórias em constante interação. O Cabra se projeta, portanto, como síntese de uma multiplicidade de experiências apreendidas através de sua retomada, o que difere bastante do filme iniciado em 1964.

Muito já se falou sobre as diferenças que os eventos históricos impingiram ao Cabra inicial e ao que veio a ser concluído vinte anos depois ${ }^{100}$. As filmagens feitas em 64 se vinculavam ao ideário da época, com boa dose de fetichização do

\footnotetext{
99 João Figueiredo foi o último representante militar da ditadura instaurada em 1964 e finda em 1988. Governou entre os anos de 1979 e 1985.

${ }^{100}$ No livro Eduardo Coutinho (OHATA, 2013), há uma série de análises fundamentais. Destaco $O$ cinema de Eduardo Coutinho: entre o personagem fabulador e o espectador-montador, Consuelo Lins; Do épico-pedagógico ao documentário, Marilena Chauí.
} 
"povo", aqui expresso na figura mitificada do camponês. Acerca das imagens que foram preservadas, Consuelo Lins enfatiza o "estilo didático-conscientizador", traço marcante nas produções do CPC e em algumas do Cinema Novo. Segundo a pesquisadora, o Cabra compartilhava de uma certa ingenuidade que permeou diversas obras do período ${ }^{101}$. A eclosão da realidade foi fundamental para que Eduardo Coutinho transformasse um filme pautado por "personagens esquemáticos desprovidos de conflitos internos em uma narrativa linear" ${ }^{102}$ numa das mais profundas reflexões sobre o país e sobre o cinema-documentário.

Cineasta decisivo nas reflexões sobre a partilha com o filmado, o próprio Coutinho creditou essa mudança em seu trabalho como documentarista à sua experiência na década de 70 no Globo Repórter: “[...] Só mesmo quando eu fui para o Globo Repórter em 1975 e passei nove anos lá, alguns deles muito produtivos, foi que eu passei a ter que conversar com as pessoas" ${ }^{103}$. Segundo Ismail Xavier, a mudança de postura assumida por Coutinho expressou uma espécie de acerto de contas de sua geração com a política representacional hegemônica nos anos 60:

O momento da partilha com o outro de classe, iniciado em termos problemáticos nos anos 60 , é recuperado no início dos anos 80 recolhendo a rica experiência do cineasta na reportagem e no documentário para rearticular a relação entre entrevistador e entrevistados de modo a figurar o processo repressivo e a diáspora da família do camponês morto - João Pedro Teixeira -, projetando sobre a viúva - dona Elizabeth - a história desse período que ele passa a personificar, tal como o próprio Coutinho personifica aí o trajeto dos cineastas empenhados na luta política ${ }^{104}$.

\footnotetext{
101 "Essas imagens [...] trazem nas características dramáticas e estéticas o valor de documento de uma determinada época, uma determinada concepção de cinema político. São fragmentos que nos fazem experimentar visualmente essa concepção, na sua versão CPC: um cinema engajado, com ousadias e riscos no esquema de produção (equipes pequenas, orçamentos baixíssimos, atores "naturais" em locações), mas sem ambigüidades ou experimentações estéticas" (LINS, 2004, p. 38).

102 Ibidem, p. 38.

${ }^{103}$ BRAGANÇA, 2009, p. 181. O período na TV permitiu que Coutinho angariasse recursos e equipamentos a fim de retomar o projeto do Cabra nos anos 80. Além disso, a experiência com a linguagem televisiva, após a brusca interrupção do filme, marcou uma reorientação da própria concepção de cinema de Eduardo Coutinho pautada no diálogo com o outro. Consuelo Lins assinala que foi na televisão que Eduardo Coutinho começou a exercitar uma capacidade de filmar a relação com o outro, de entrevistar e de se envolver com o entrevistado (LINS, 2004, p. 20).

104 XAVIER, 2012, p. 26.
} 
Os muitos momentos nos quais o diretor se coloca em cena ou dialoga com o espectador através de suas reflexões são expressivos da mudança de postura mencionada por Ismail Xavier. Coutinho surge, em meio aos demais, como mais um personagem daquela epopeia utópica que, de forma complicada, abrangeu estudantes universitários, operários e camponeses.
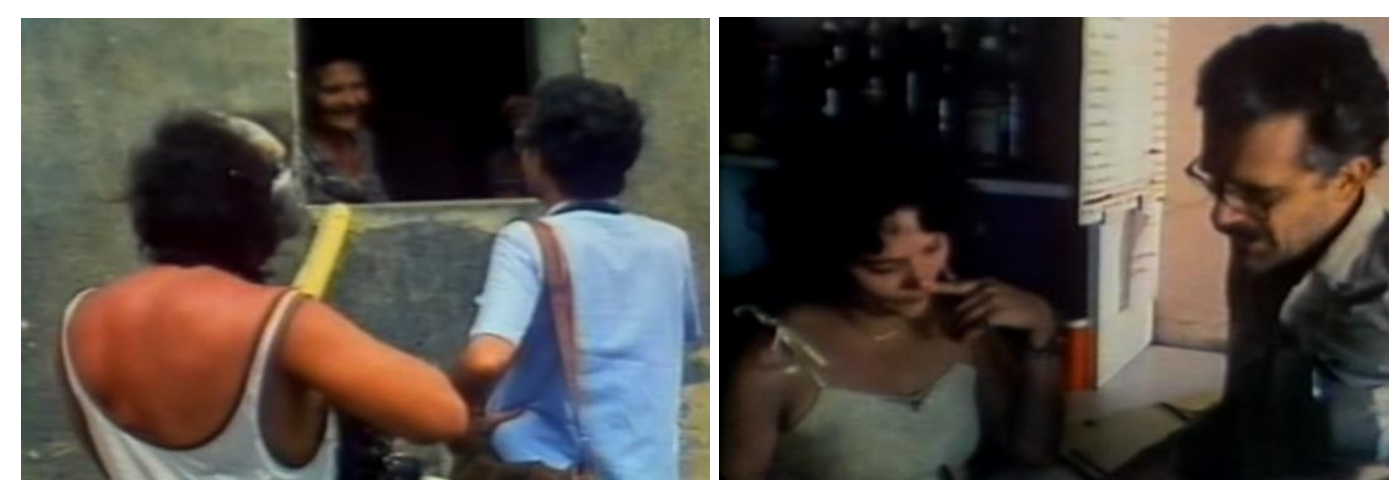

Fig.26. Eduardo Coutinho e a equipe de filmagem em cena.

Se as antigas imagens se revelavam "desprovidas de ambiguidades", ao assumir os conflitos internos no corpo do documentário, Coutinho trazia de forma íntegra a relação fílmica gerada. Por volta do minuto 53, em meio ao depoimento de João Mariano, que interpretara o papel de João Pedro, Coutinho solicita bruscamente que a equipe interrompa a filmagem, pois o vento estaria atrapalhando a captação do som. Interrupção atendida, em seguida João Mariano hesita um tanto em retomar seu depoimento e um constrangimento toma conta da cena. Após sucessivos pedidos de Coutinho, João Mariano se recompõe e volta ao seu relato, possivelmente mais ponderado que antes da interrupção, mas ainda assim repleto de ambiguidades. João Mariano diz, então, que prestava aquele depoimento por conta da simpatia de Coutinho, mas que não tinha envolvimento algum com "esse negócio de revolução", não sabia o que estava fazendo quando do tempo das filmagens de 1964, e o seu afastamento do engenho era uma prova de que não queria tomar as propriedades de ninguém. Adiante, Coutinho lhe pergunta se havia sido prejudicado pelas filmagens. João Mariano responde: "Não fui prejudicado porque fiz o filme. Fui prejudicado pelo senhor de engenho. Depois mesmo, naquela revolução, o senhor de engenhou me perseguiu para matar-me [...] porque me indenizou o engenho". E, por fim, declara que ficou satisfeito ao ter visto as imagens projetadas no dia anterior, pois vira o fruto do 
seu trabalho. Essa sequência em torno de João Mariano é interessante, pois fica expressa a mudança de postura que a conversa com Coutinho lhe proporcionou. João Mariano, sensivelmente, abandona a postura inicial desconfiada e passa a rememorar alguns fatos e emitir impressões pessoais, como a importância da religião em sua vida. Além disso, podemos apreender também os não-ditos, as lacunas de uma história de repressão que ficam inscritas em seu discurso vacilante.

Outra sequência importante ocorre no encontro de Coutinho com José Eudes, um dos filhos de Elizabeth Teixeira espalhados pelo país, precisamente no Rio de Janeiro. Ao chegar à fábrica em que Eudes trabalhava, Coutinho é interpelado por um rapaz se as filmagens seriam da TVE ou da TV Globo, respondendo: "É cinema. É tipo televisão, é reportagem, mas é cinema”. Aparentemente inocente, esse trecho inscreve a política que separa o documentário do jornalismo que Coutinho apreendera nos anos de Globo Repórter ${ }^{105}$. Ao encontrar José Eudes, este solicita a Coutinho que façam uma reunião fechada antes de prestar seu depoimento, tendo seu pedido prontamente aceito pelo diretor.

Tanto na sequência com João Mariano quanto com Eudes, Coutinho não se exime na montagem. Diferente de uma narrativa com vistas a imprimir objetividade, a qual editaria trechos "impuros" e encadearia os fatos almejando naturalidade, os constrangimentos, as negociações, as "falhas" são parte constituinte da ação gerada e filmada no Cabra. O filme de Coutinho se constrói, portanto, "sob o risco" e "em fricção com o real":

\begin{abstract}
À sua maneira modesta, o cinema documentário, ao ceder espaço ao real, que o provoca e o habita, só pode se construir em friç̧ão com o mundo, isto é, ele precisa reconhecer o inevitável dos constrangimentos e das ordens, levar em consideração (ainda que para os combater) os poderes e as mentiras, aceitar, enfim, ser parte interessada nas regras do jogo
\end{abstract}

\footnotetext{
${ }^{105}$ Como síntese, recorro à famosa sequência de Seis dias em Ouricuri (1976) comentada por Coutinho: "[...] Agora, o que quebra o padrão de jornalismo de lá é que você tem um plano extraordinário, que é o melhor plano que eu fiz em toda a minha vida, em que um cara conta para frente das câmeras que come raízes e tem mais três caras que aparecem dizendo que raízes já comeram e que o outro cara vai mostrando. Mas ele é um cara delicado, interessante. E é um plano de três minutos e dez segundos, um plano impossível de passar no jornalismo da época e ainda mais nos dias de hoje, mas não é porque fala de miséria, não é isso, é porque não passa, não passa; não se faz um jornalismo para contemplar, para refletir, mas se faz para a urgência, sob pressão. [...]. É preciso saber lidar com a falta de liberdade. Lutar e saber manter algumas brechas é a verdadeira ação política que se pode ter ainda hoje. Como eu sempre digo, a forma é o conteúdo. É assim que eu faço política" (SACRAMENTO, 2008, p. 202).
} 
social. Servidão, privilégios. Um cinema engajado, diria eu, engajado no mundo ${ }^{106}$.

Esse tipo de postura assumida pelo filme não permite a crença em representações transparentes da realidade ou no seu encampamento em relatos absolutos de seus personagens. Toda a articulação do Cabra se orienta a ressaltálo como um agente produtor de significados e, portanto, dotado de posicionamentos e subjetividades.
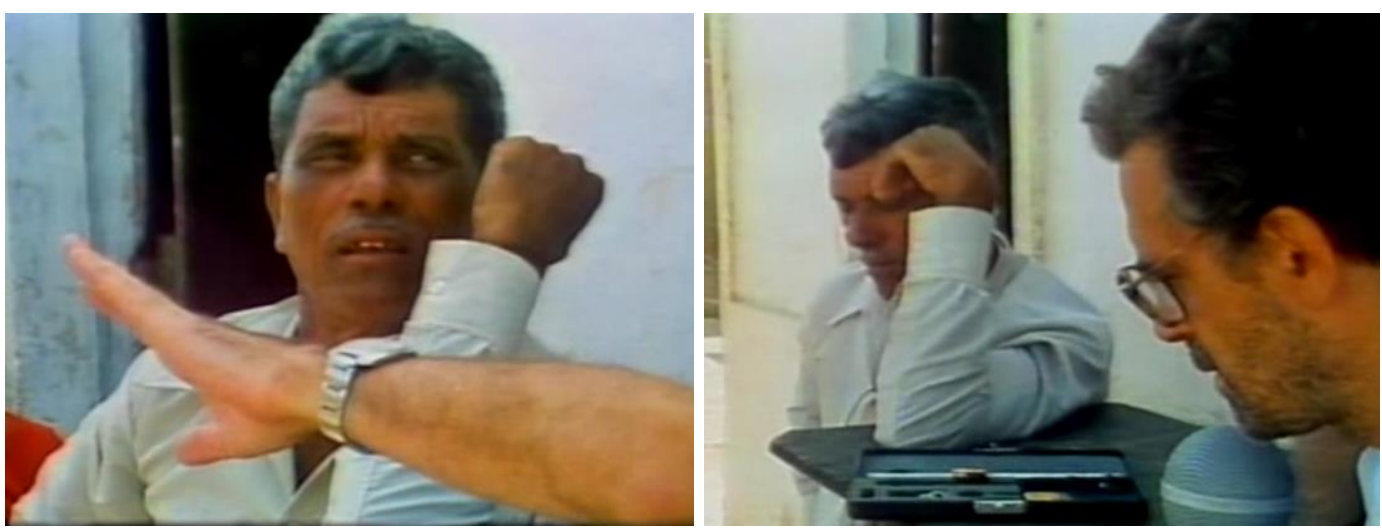

Fig.27. Momento de interrupção e hesitação na conversa com João Mariano.

As hesitações, os discursos vacilantes, os silêncios, expressam uma história marcada por lacunas e apagamentos. Em um país no qual, com frequência, é aplicada a "política do esquecimento", recontar a história dos oprimidos (apesar de tudo) consiste, centralmente, em um ato político contra a homogeneização do tempo. Porém, enquanto filmes vinculados à uma lógica expositiva e generalizante se veriam em um decisivo impasse em meio à precariedade de um córpus consistente de fontes, documentos e relatos, é justamente daí que Cabra marcado para morrer extrai sua potência.

Podemos vislumbrar o trabalho de Coutinho através do "paradigma indiciário", formulado por Carlo Ginzburg. Brevemente, em Sinais: Raízes de um paradigma indiciário, o historiador italiano procurou estabelecer uma genealogia de um novo método de investigação pautado por sintomas, indícios, vestígios singulares, método este que se colocava como alternativa às quantificações reprodutíveis do hegemônico "método galileano". Para tal, Ginzburg aproximou formulações dos campos estético (Giovanni Morelli), psicanalítico (Sigmund 
Freud) e investigativo (Sherlock Holmes), as quais teriam em comum a busca pelos resíduos, possibilitando novas apreensões qualitativas de determinado fenômeno ${ }^{107}$. Nesse sentido, Ginzburg assinalou que, ante uma realidade opaca, "existem zonas privilegiadas - sinais, indícios - que permitem decifrá-la"108, em outras palavras, "pistas talvez infinitesimais permitem captar uma realidade mais profunda, de outra forma inatingível.",109

De modo similar ao método postulado pelo historiador italiano, Coutinho passa ao largo de uma pretensão em capturar aqueles eventos em sua totalidade ou estabelecer uma generalização reprodutível. Rastreando, como um detetive ou um médico, todo tipo de sinais, vestígios e sintomas que envolveram as filmagens do antigo Cabra, Coutinho procura a singularidade daquelas experiências a fim de "captar uma realidade mas profunda". Sobre este aspecto é particularmente expressivo o momento do Cabra no qual a história de João Pedro Teixeira é contada, justamente, na ausência quase total de vestígios. Percorrendo imagens da estrada onde ele foi assassinado, na qual foi construído um monumento em sua homenagem prontamente dinamitado nos primeiros dias de abril de 1964, e o cemitério onde seu corpo foi enterrado, a narração nos informa que em seu túmulo não há nenhuma inscrição e que, tampouco, sobrou alguma fotografia de João Pedro vivo. Essa sequência se encerra com a fotografia de João Pedro morto.
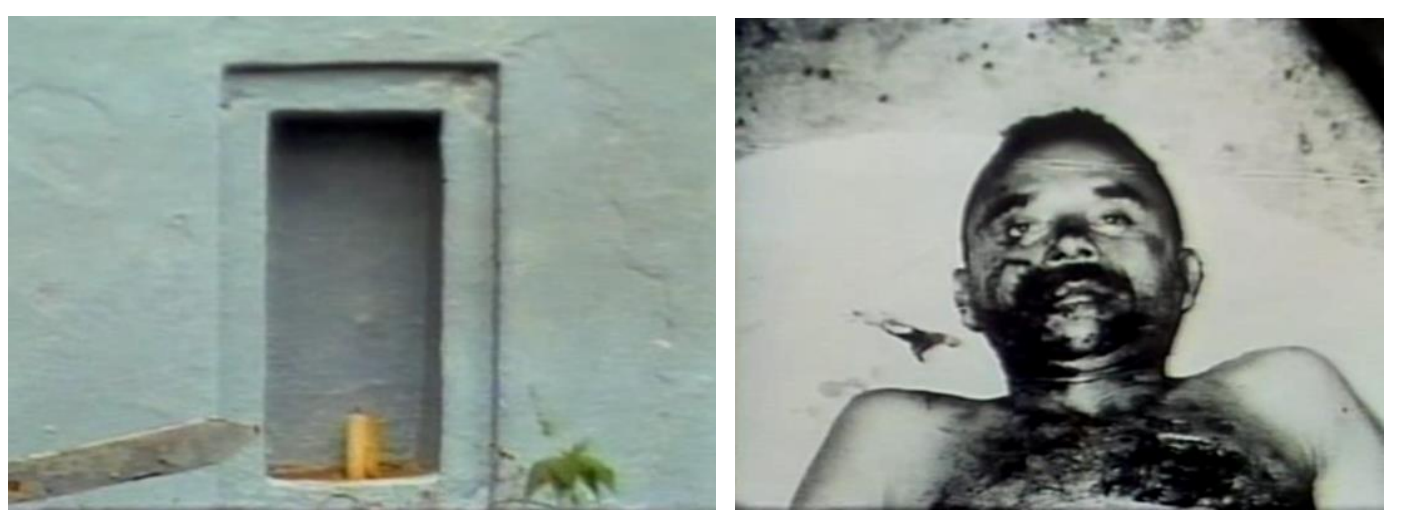

Fig.28. A ausência de vestígios de João Pedro Teixeira.

Fig.29. A única fotografia de João Pedro Teixeira.

\footnotetext{
107 “[...] É o próprio Freud a indicá-lo: a proposta de um método interpretativo centrado sobre os resíduos, sobre os dados marginais, considerados reveladores. Desse modo, pormenores normalmente considerados sem importância, ou até triviais, "baixos", forneciam a chave para aceder aos produtos mais elevados do espírito humano" (GINZBURG, 1989, p. 149-150).

${ }^{108}$ Ibidem, p. 177

${ }^{109}$ Ibidem, p. 150.
} 
Em seguida, vemos imagens da casa onde João Pedro passou os últimos anos de sua vida e a locução de Gullar assinala que, em 1981, 17 anos após a fuga de Elizabeth, seus filhos não sabiam onde ela estava ou se ao menos estava viva. Ali perto da casa onde a família Teixeira morou, Coutinho, então, realiza o primeiro encontro no filme com um dos filhos de Elizabeth e João Pedro, notadamente, Maria das Neves Altina Teixeira, a "Nevinha". Esta revela haver conhecido pouco seu pai, pois era muito jovem, e ter saudades da mãe, inclusive prestando-lhe homenagem ao pôr o nome "Elizabeth" em sua filha. O próximo encontro é com João Pedro Teixeira Filho, "Pêta", que fora criado pelo avô após a fuga de sua mãe. Pêta conta que ele e seus irmãos não morreram por causa da família que os abrigou, mas que, apesar disso, não tinha raiva da mãe e queria vê-la de qualquer modo. Conta também que não possuía nenhum retrato de seu pai nem de sua mãe, não restando-lhe lembrança alguma. Desse modo, Pêta procurou, de toda forma, reconstruir o monumento em homenagem a seu pai que fora dinamitado como forma de rememorá-lo ${ }^{110}$.

Em seguida, há um breve relato de Manoel Justino da Costa, no qual, sem pronunciar seu nome, assinala que João Pedro não deu ouvidos a seus conselhos e que, portanto, haviam se tornado inimigos. Vemos, em seguida, Manoel Justino da Costa sair de carro com Pêta e a narração de Gullar nos diz: "Nessa estrada, logo adiante, ainda nas terras de Manoel Justino, João Pedro foi assassinado. No tempo das Ligas, Elizabeth passava por aqui liderando passeatas até o monumento em memória do marido". A ausência e a persistência do monumento de João Pedro como disputa pela sua memória, a falta de informações dos filhos sobre Elizabeth Teixeira, o não pronunciamento do nome de João Pedro por Manoel Justino e a sua hesitação em dar um depoimento, a vontade dos filhos de rever sua mãe, o túmulo sem inscrição, compõem os resíduos que Coutinho vasculha como forma de "captar uma realidade mais profunda", a experiência lacunar que só se concretiza na singularidade daquelas pessoas.

Desse modo, ao contrário da lógica narrativa clássica, Cabra marcado para morrer não ruma para um fim almejando alguma resolução. Sua estrutura é marcadamente descontínua, em um emaranhado de vestígios do antigo filme, notícias de jornal, vídeos da época, narração em voz off e, sobretudo, os

\footnotetext{
${ }^{110}$ Esse gesto de Pêta ecoa uma das máximas de Walter Benjamin: "[...] também os mortos não estarão em segurança se o inimigo vencer [...]” (BENJAMIN, 2012, p. 244).
} 
depoimentos de indivíduos que não haviam tido a oportunidade de contar sua história. O único fio narrativo que conduz o Cabra é a sua busca e, por conseguinte, o encontro gerado. Esse gesto promove a suspensão temporal que Jean-Louis Comolli define como princípio ético-político do documentário:

O mais simples dos gestos cinematográficos, fazer um plano fixo, por exemplo, filmar uma entrevista, uma rua, montar um arquivo [...] corresponde a nada menos que colocar o mundo em suspenso. E, ao mesmo tempo, colocar o sentido em movimento ${ }^{111}$.

É nesse espaço-tempo promovido pela ação do filme que tudo ocorre. São emblemáticos dessa postura os momentos de rara beleza nos quais os camponeses se vêem enquanto antigos personagens do filme interrompido e, reconhecendo-se a si e uns aos outros, pouco a pouco fazem emergir suas histórias banais. A estrutura de Cabra marcado para morrer é operada dentro desse sistema, articulando sua condução narrativa pelas imagens que atualizam o passado. Nesse sentido, com frequência, o filme conecta as imagens dos personagens no presente com as antigas imagens projetadas na tela e também com a marcante fotografia da família Teixeira quando do luto pela morte de João Pedro. Esse recurso de montagem vem a reforçar os sentidos que o documentário mobiliza em torno da história. Esta surge não de forma abstrata, morta, mas materializada nas expressões e gestos daquelas pessoas filmadas, como em João Virgínio, “o valentão das Ligas Camponesas" que relata ter perdido a visão de um olho nas sessões de tortura, violência que presenciamos em sua imagem atualizada.
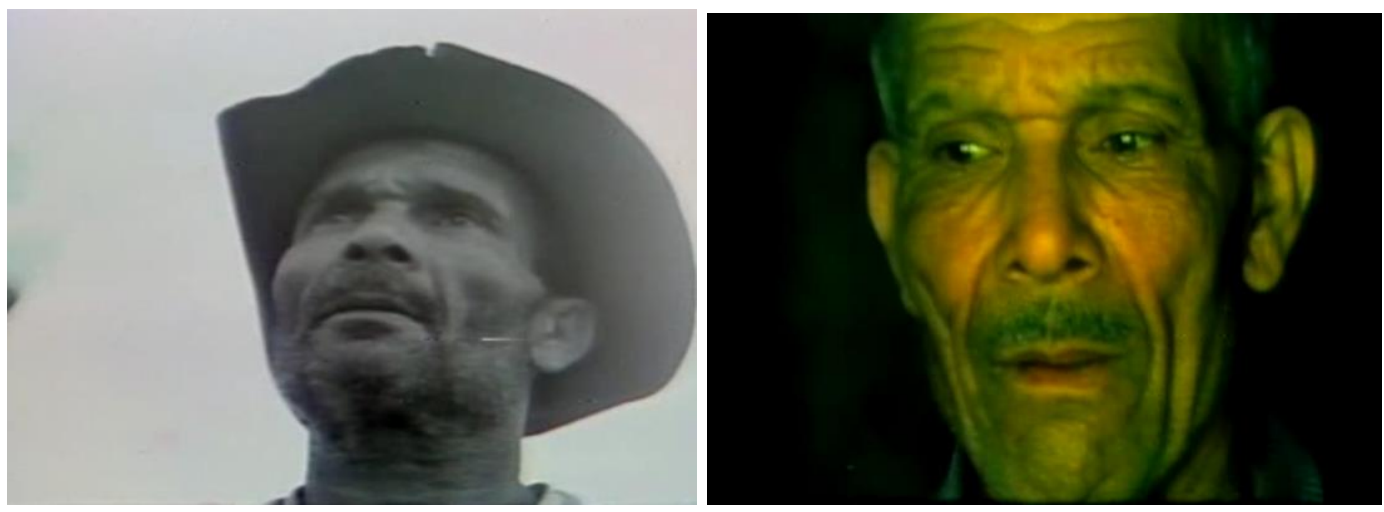

Fig.30. Passado e presente em Cabra marcado parar morrer.

111 COMOLLI, 2008, p. 269. 
Os depoimentos, extremamente relevantes no Cabra, ainda que sejam motivados pela busca de Coutinho, manifestam-se de forma ativa na construção de sentidos e aberturas de lacunas no filme, reverberando o ato mnemônico que Walter Benjamin assinalou em contraposição à história linear. Coutinho constrói seu filme, então, na própria tessitura daquelas memórias que se adensam ao inquirir os tantos anos transcorridos desde as primeiras filmagens. Esse gesto caminha num sentido outro que o estabelecimento de generalizações e "tipos" sociais. Ainda que, claramente, vejamos camponeses na tela, estes se revelam enquanto individuações, tecendo um emaranhado de experiências ordinárias.

"Como passar do indivíduo à massa? Questão política. Como passar da coletividade ao sujeito? Questão cinematográfica" ${ }^{112}$. Com esta sentença, JeanLouis Comolli define precisamente a dialética entre estética e política no cinema. A coletividade, alvo da emancipação política, torna-se sujeito na imagem através de um gesto que envolve a duração:

\begin{abstract}
A ficção é a duração. $\mathrm{O}$ documentário, quando retrabalha as dimensões da ficção, é também, claro, arte da duração. A duração e a ficção, juntas, são a ideia de transformação. [...] A duração é o tempo para que alguma coisa se transforme e, antes de tudo, para que uma relação se estabeleça ${ }^{113}$.
\end{abstract}

Ao filmar uma relação, ao potencializar sua duração, entramos no terreno das ambiguidades, das contradições, da própria ficção enquanto deslocamento político. É na duração que algo se transforma, que o filmado se desamarra dos lugares pré-concebidos e revela a sua complexidade. É possível perceber, em Cabra marcado para morrer, um projeto que Coutinho levaria adiante em outros filmes, a saber, a busca pelo ser tal-qual, isto é, os seres que expõem suas singularidades ante as tentativas midiáticas que ora tentam esvaziá-los em seres indistintos (o "qualquer um") ora classificá-los em classes, grupos étnicos, etc ${ }^{114}$. São seres que, através da duração gerada pelo filme, assinalam tanto um passado, uma memória, quanto um devir, emancipados no "presente impuro" da filmagem, gesto estético-político sinalizado por Serge Daney.

O presente aqui deve ser entendido em um sentido mais amplo,

\footnotetext{
112 COMOLLI, 2007, p. 128.

${ }^{113}$ Ibidem, p. 128.

${ }^{114}$ AGAMBEN, 1993.
} 
não apenas o presente instantâneo da atualidade, mas também o presente da rememoração ou evocação, ou aquele em que conseguimos discernir a emergência do que está por vir. Um presente impuro, justamente, que ao ser registrado pela câmera revela o trabalho do tempo e a coexistência dos fluxos da vida naquele momento ${ }^{115}$.

A expressão maior de como o filme incide de modo a desdobrar o real na atualidade das filmagens consiste na metamorfose que presenciamos em Elizabeth Teixeira. Abandonando o "exílio" pela ação do filme, aos poucos Elizabeth começa a retomar sua vida e rememorar sua experiências. Esse processo culmina na sequência final, na qual Elizabeth se coloca de forma oscilante ao afirmar, por um lado, que nunca havia esmorecido e esquecido a luta e, por outro, agradecendo novamente ao presidente pela honra de poder estar junto a Coutinho e reencontrar sua família. Ao se despedirem, Elizabeth, então, abandona a ambiguidade anterior e, de modo enfático, profere o famoso discurso conclamando a continuidade da mesma luta de $1964^{116}$.

Embora a própria realização do Cabra aponte para os anos de ditadura como uma interrupção na história nacional, dado que só pôde ser concluído no processo de redemocratização, o discurso final de Elizabeth Teixeira revelava as continuidades de um regime que se transmutou através de um grande pacto nacional, mantendo a dominação de classe e as desigualdades sociais. Essa fala de Elizabeth é também mais uma evidência da pobre representação que Céu Aberto propôs acerca do povo na mesma conjuntura que o filme de Coutinho. A distância da proposta cinematográfica de Cabra marcado para morrer em relação aos filmes do capítulo 1 pode ser melhor apreendida nas próprias palavras de seu diretor:

Muitos dos documentaristas ditos progressistas, de esquerda ou de qualquer forma interessados no social, costumam filmar aqueles acontecimentos ou ouvir aqueles personagens que

\footnotetext{
${ }^{115}$ FRANÇA; LINS; GERVAISEAU, 1999.

116 "A luta não pára. A mesma necessidade de 64 está plantada. Ela não fugiu um milímetro. A mesma necessidade está na fisionomia do operário, do homem do campo e do estudante. A luta que não pode parar. Enquanto se diz que tem fome e salário de miséria, o povo tem que lutar. Quem é que não luta por melhores dias de vida? Tem que lutar. Quem tem condições, quem tem sua boa vida que fique aí. Eu, como venho sofrendo, eu tenho que lutar e tenho peito de dizer: é preciso mudar o regime, é preciso que o povo lute. Enquanto tiver esse regimezinho, essa democraciazinha aí... democracia sem liberdade, democracia com salário de miséria, de fome, democracia sem o filho do operário e do camponês ter direito de estudar, ah... não pode, ninguém pode."
} 
confirmem suas próprias ideias apriorísticas sobre o tema tratado. Daí se segue um filme que apenas acumula dados e informações, sem produzir surpresas, novas qualidades não previstas. O acaso, flor da realidade, fica excluído. Creio que a principal virtude de um documentarista é a de estar aberto ao outro, a ponto de passar a impressão, aliás verdadeira, de que o interlocutor, em última análise, sempre tem razão. Ou suas razões. ${ }^{117}$

O gesto de Cabra marcado para morrer difere de todos os filmes analisados até aqui, inclusive de Que bom te ver viva, dado que este se concentra num tipo social e explora suas reflexões através da teatralização e do constante diálogo da narração com os depoimentos. Ao contrário, o filme de Coutinho produz a fabulação com seus personagens na própria cena documental. Desse modo, através das memórias, trajetórias e impressões daquelas pessoas, as asserções que o Cabra agencia se orientam para a abertura da história em detrimento de uma sucessão de sentenças a encadear e fechar um sentido unívoco. Os silêncios, as hesitações, as ambiguidades, colocam-se no mesmo patamar que os relatos mais coerentes e lineares, pois as vivências concretas são marcadas por falhas, imperfeições, receios, busca de sentidos em meio ao caos da existência. E o filme surge, portanto, como síntese desse processo ao dispará-lo. Por outros caminhos, a abertura da história se verifica também nos documentários do capítulo 3, os quais, longe de procurar algum sentido, radicalizam os próprios princípios de sobriedade estabelecidos no campo documental.

${ }^{117}$ COUTINHO, 2015, p. 230. 


\section{3. \\ O ataque à sobriedade em dois documentários dos anos 80}

\section{1.}

\section{A postura antiilusionista}

Neste capítulo, analiso aspectos formais de Jânio a 24 quadros (1981, Luiz Alberto Pereira) e Mato eles? (1982, Sergio Bianchi). Embora sejam filmes que também trataram de questões candentes do Brasil, o fizeram de forma indireta. Ambos são documentários nos quais a forma prevalece ante o enunciado. Além disso, o próprio tom que articulam, contaminados por ironia e sarcasmo, vem centralmente a investir contra as representações sóbrias e transparentes do real. São filmes que implodem, desconstróem a objetividade que predomina no documentário, revelando-se primordialmente como um lócus de produção de significados.

A desconstrução no cinema não é recente. Ismail Xavier demonstra que foi em meio aos debates acalorados de Maio de 68 que o movimento desencadeado pela revistas francesas Cahiers du Cinéma e Cinéthique buscou alternativas críticas ao que se chamou "cinema-espetáculo", isto é, ao modo hegemônico do cinema clássico pautado pela ilusão da narrativa:

\footnotetext{
$\mathrm{O}$ ataque dos críticos dirige-se à combinação de três enunciados dogmáticos: o mundo é "pleno de sentido"; o sujeito é capaz de captar as verdades essenciais e o "sentido" de tal mundo; a linguagem, como instrumento de representação, expressa, em sua clareza, o pensamento do sujeito que conhece ${ }^{118}$.
}

Postulou-se, nesse sentido, um cinema antiilusionista que revelasse a si próprio enquanto engranagem social a nível ideológico e de processo de trabalho contra qualquer tipo de atividade mimética a mascarar e reproduzir a lógica da sociedade burguesa. Não por acaso, Dziga Vertov e sua obra-prima $O$ Homem da Câmera (1929) foram uma das principais referências desse movimento.

Silvio Da-Rin assinala que, até os anos 80, pouco se viu de experimentação estética no documentário brasileiro que confrontasse a perspectiva ilusionista. A prioridade do campo, até então, colocava-se entre registrar a cultura popular e denunciar as injustiças sociais. Como ponto fora da curva, Da-Rin assinala o

\footnotetext{
${ }^{118}$ XAVIER, 2005, p. 146.
} 
trabalho pioneiro de Arthur Omar em seus filmes Congo (1972) e Tesouro da Juventude (1977), obras de difícil classificação por seu intenso diálogo com as artes plásticas e a articulação de sentidos não evidentes. São filmes que investem totalmente contra qualquer mimetização do real, assinalando seu caráter essencial de "objeto-filme" constituído de elementos significantes ${ }^{119}$.

Jean-Claude Bernardet abordou essa cinematografia pelo prisma da "voz do documentarista”. Acrescentando a Congo filmes anteriores como Indústria (1968, Ana Carolina Teixeira) e Lavrador (1968, Paulo Rufino), Bernardet assinala o deslocamento, nesses documentários, da enunciação da voz do outro para si próprios. O crítico sintetizou Lavrador da seguinte forma:

[...] O filme não nos encaminha para discutir a reforma agrária, mas para discutir um filme que trata da reforma agrária. $\mathrm{O}$ discurso cinematográfico coloca-se em primeiro plano e cria obstáculo para a sua apreensão. E sente prazer ao resistir ao nosso esforço de decifração. Ao fazer isto, ele nos lembra constantemente que não é o real, mas é composto com elementos relacionados com este real e selecionados heterogeneamente pelo cineasta $[\ldots]^{120}$.

Percebe-se, assim, entre os anos 70 e 80 uma gradual inflexão de documentários que passaram a privilegiar a sua própria textura fílmica. Em sua análise de Mato eles?, José Carlos Avellar observava um "fato novo" no cinema brasileiro. A lógica metalinguística e caótica do filme de Sergio Bianchi dava continuidade, segundo Avellar, ao projeto iniciado por Glauber Rocha na TV e em seu documentário Di-Glauber ainda nos anos 70:

[...] esta coisa que talvez tenha pintado primeiro no $D i$ é uma certa desmontagem do sistema do filme documentário através de uma interferência doida, caótica, debochada até, do realizador dentro da cena: ele vem, filma, participa e fala de tudo, do tema do filme, do cinema, dele mesmo. $\mathrm{O}$ fato novo está aí ${ }^{121}$.

Os dois filmes analisados neste capítulo foram realizados por diretores de uma geração posterior aos dos capítulos 1 e 2. Tanto Sérgio Bianchi quanto Luiz

\footnotetext{
${ }^{119}$ DA-RIN, 2004.

${ }^{120}$ BERNARDET, 1985, p. 77.

${ }^{121}$ AVELLAR, José Carlos. “'Mato eles?' e 'Chapeleiros' - a arte de fazer perguntas”. Jornal do Brasil, 06/12/1983.
} 
Alberto Pereira se formaram na Escola de Comunicações e Artes da USP, durante a década de 70. Portanto, atravessados pelos novos questionamentos que o documentário vinha maturando sobre si, o que fica evidenciado em sua linguagem.

\title{
3.2.
}

\section{Jânio a 24 quadros: O Brasil é uma chanchada}

É curioso perceber que praticamente todos os personagens abordados nos filmes dos capítulos 1 e 2, tanto coletivos quanto individuais, estão presentes no filme Luiz Alberto Pereira, o "Gal”: Juscelino Kubitschek, Lula, João Goulart, Tancredo Neves, Leonel Brizola, o movimento estudantil, a guerrilha urbana, os generais da ditadura, e até mesmo a saída encontrada por alguns em buscar retiros espirituais. No entanto, longe de alguma denúncia social ou de qualquer contribuição com algum movimento político, aqui eles compõem a grande chanchada com a qual o diretor representou o Brasil. Ao contrário da grande maioria dos documentários, a montagem exagerada e acentuadamente debochada de Jânio a 24 quadros incide de modo a desmitificá-los, operando-se, assim, a própria desmonumentalização da história brasileira. Nas palavras do próprio Gal:

\begin{abstract}
Ao contrário do que muitos pensam, o filme não tem pretensões mais sérias além de ser um discurso sobre a incoerência da vida política brasileira nos últimos 30 anos, com muito humor e procurando tratar as personalidades da política como personagens, não como mitos. Todas as pessoas que aparecem no filme, inclusive as da nova geração, que dão seus depoimentos, são personagens de um painel que, embora diferente do documentário tradicional, procura transmitir ao espectador uma informação a respeito dessas últimas três décadas. Nós preferimos profanar o tempo e, em vez de realizar especificamente um filme sobre Jânio ou outras personalidades de época [...] optamos por fazer algo mais fácil, sem precisão linear, como um jogo de cenas. Sua comunicação surge mais pelo humor, aquele velho humor da chanchada que debochava dos fatos ${ }^{122}$.
\end{abstract}

"Aquele velho humor que debochava dos fatos" encontrou o disparador perfeito. Enquanto João Goulart pode ser visto como a própria expressão da tragédia em nossa história, Jânio, figura bastante controversa, consiste no lado

122 “Jânio, a revolução russa e a imprensa em três filmes”, Folha de São Paulo, 01/09/1982. 
cômico do Brasil que a chanchada explorou largamente. Chanchada essa que não se restringe a Jânio Quadros, mas que, ao atravessar todo o filme, surge como um elemento constituinte da nossa formação cultural. Nesse sentido, a imagem da vassourinha no clássico jingle de Jânio Quadros "Varre, varre, varre vassourinha, varre a corrupção" ecoa por todo o filme como um deboche da suposta moralidade que reveste os discursos oficiais, os quais, indiretamente, são derrubados um a um.

Jânio a 24 quadros é, portanto, um convite a percorrer, de modo essencialmente descontínuo e bem-humorado, os principais eventos e personagens célebres dos anos 60, 70 e 80 do Brasil. Enquanto Mato eles? perturba a sobriedade documental através da ironia, em Jânio a 24 quadros, ainda que ela se faça presente, o tom que predomina é o deboche declarado acerca dos descaminhos da história nacional.

O principal recurso narrativo do filme de Gal reside na montagem. Ao longo de todo o documentário ocorre a justaposição, por vezes frenética, de imagens de arquivo, comerciais televisivos, jornais, revistas, encenações, jingles, locuções radiofônicas, marchinhas, músicas as mais variadas, numa intensa "poluição" de imagens e sons, assinalando "um jogo de artifícios que procura integrar a própria disjunção entre essas imagens, mídias e materiais, de modo a fazer do intervalo um elemento produtivo e fundamental" ${ }^{\prime 23}$.

A disjunção, portanto, como recurso estético que em seu contraste heterogêneo convida, invariavelmente, a refletir sobre o que e como se está vendo aquela história. O desconforto gerado por imagens tão "estranhas" entre si incide de modo a não permitir que a apreensão se dê de forma objetiva.

Como exemplo, recorro ao minuto 20 do documentário, onde ouvimos uma sucessão de jingles (verdadeiras marchinhas de carnaval) com imagens dos candidatos às eleições presidenciais de 1960 (Jânio Quadros, Adhemar de Barros, Marechal Henrique Teixeira Lott, João Goulart), num tom acentuadamente farsesco. Jânio vencia e, então, sua posse é exibida ao som de Diana (Paul Anka), uma típica balada romântica dos anos 60 que acompanhava imagens de Jânio e outras figuras destacadas, como Carlos Lacerda, numa comemoração da alta sociedade. Corte para Jânio em seu gabinete. Ainda ao som de Diana, a narradora

\footnotetext{
${ }^{123}$ FRANÇA, 2015, p. 57.
} 
nos informa que ele começara seu governo reclamando da crise econômica em que o país se encontrava e, com isso, atacava publicamente o legado de Juscelino Kubitschek. Após enumerar uma série de medidas de caráter econômico, com imagens de Jânio sendo saudado pela Marinha, a narradora nos diz:

[...] essas foram algumas medidas do novo governo. Outras foram mais estranhas: proibiu o lança-perfume, a briga-de-galo, a corrida de cavalo em dias úteis e o uso dos maiôs nos desfiles de miss, porém o fato mais marcante do seu governo de 7 meses foi a política externa.

Nesse momento, a narração é interrompida e, ainda acompanhada da canção, vemos durante alguns segundos uma fotografia de Jânio de pernas cruzadas, vindo a adensar ainda mais o tom farsesco iniciado com as marchinhas e prosseguido pela narração inusual.

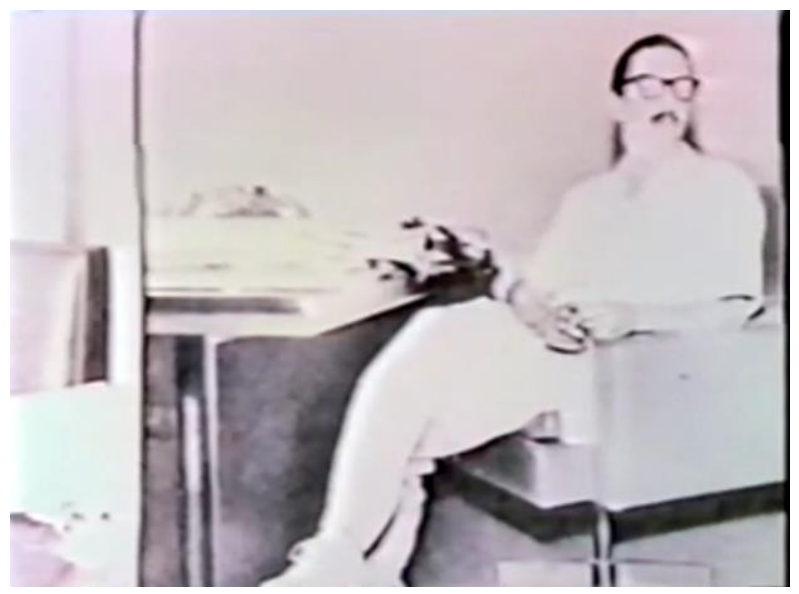

Fig.31. O farsesco em Jânio a 24 Quadros.

A seguir, junto a Jânio Quadros, Arturo Frondizi (presidente da Argentina) celebrava as boas relações estabelecidas entre os países naquele encontro. Corte para um discurso de John Kennedy (não traduzido, tampouco legendado), no qual atacava o comunismo de Cuba. Um mapa-múndi assinala a América do Sul ao som de Besame mucho (Emilio Tuero) e, em seguida, surge um dos momentos mais hilários do filme através de uma encenação. Interpretando Jânio Quadros, o próprio diretor do filme, Gal, proferia um discurso extremamente farsesco a um ator que interpretava o Tio Sam: 
O que é bom para um povo, é bom para um povo. O que é bom para os cubanos, é bom para os cubanos. O que é bom para os americanos, é bom para os americanos. O que é bom para os brasileiros, é bom para os brasileiros. Não vou invadir Cuba.

Na mesma sequência, ao som do ponto de umbanda Ogum já foi Coroné ${ }^{124}$, acrescido de um discurso revolucionário sobre Cuba, Gal e o montador do filme, Augusto Sevá, reencenavam a polêmica condecoração de Jânio Quadros a Ernesto "Che" Guevara. Encerrando essa sequência, é exibido o trecho de um discurso de Jânio Quadros:

[...] um democrata que acredita na livre empresa, mas transige com os socialistas no atendimento de várias das exigências da vida moderna [...] a crescente intervenção do Estado no econômico, mesmo nas democracias mais ortodoxas, comprova, porém, o que afirmei, isto é, não pode a moderna democracia deixar de oferecer aspectos totalizantes [...].

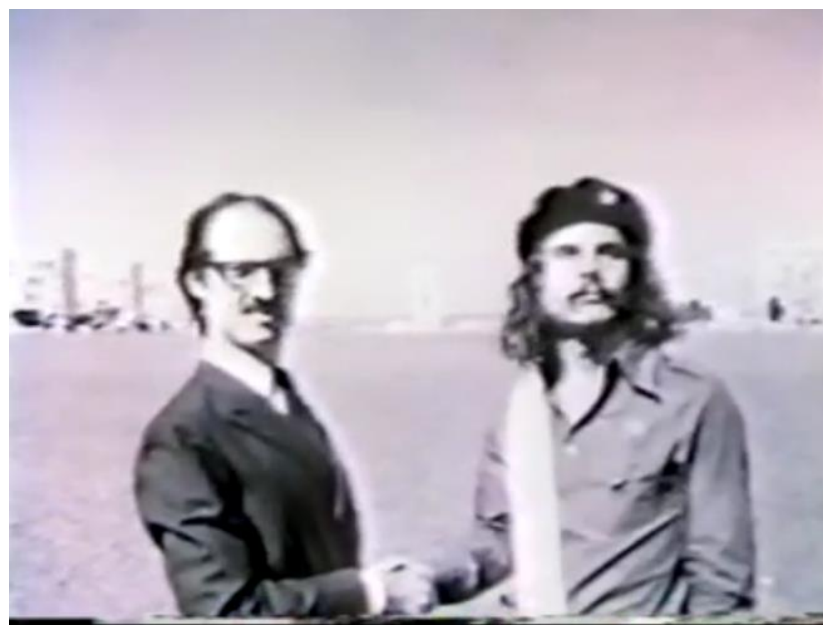

Fig.32. Encenação da condecoração de Jânio Quadros a Ernesto "Che” Guevara.

Possivelmente, não há síntese melhor da figura de Jânio que esse momento tão idiossincrático. Em meio a várias pausas, o ex-presidente da República acabava, como em outros tantos momentos no filme, por não dizer nada. Essa é a forma de (des)construção de Jânio a 24 quadros. Os arquivos não são tomados como algo "sagrado", ao contrário, são constantemente desmontados e remontados,

${ }^{124}$ Os pontos de umbanda e candomblé foram marcantes em várias obras clássicas do Cinema Novo, como os filmes Barravento (1962) e Terra em Transe (1967), ambos de Glauber Rocha. A sua utilização em Jânio a 24 quadros a deslocava da "estética da fome" para o mosaico de caricaturas no filme de Luiz Alberto Pereira. 
subvertidos, articulados à encenações explicitamente farsescas, compondo a chanchada epopeica operada no filme. Sob o humor de Jânio a 24 quadros, nenhum sentido é definido, mas vários são levantados. A partir dessa sequência e de outras tantas, podemos refletir, por exemplo, sobre a "orgia política" que atravessa a República brasileira e o período ditatorial, onde personagens retornam incessantemente através de outras roupagens conjunturais, porém sempre revestidas do conteúdo moralista. Jânio a 24 quadros opera, a um só passo, um ataque à sobriedade documental e à falsa moralidade nacional. Ambos se inscrevem no próprio corpo do filme, e não em uma lógica exterior que contaria que assim funcionam as coisas no Brasil.

Nesse sentido, é marcante a apresentação de Adhemar de Barros, personagem político famoso pelo lema "Rouba, mas faz", ao som de Rua Augusta / O Bom (Raul Seixas), com destaque para o trecho "Vai, vai Alfredo, quem é da nossa gangue não tem medo...”. Em tom descontraído, a narradora introduz: "E aí vai o Adhemar de Barros pro Palácio dos Campos Elíseos...”. Prosseguindo, informavanos que Jânio Quadros perdera a última eleição direta para o governo de São Paulo para "seu velho rival", Adhemar de Barros que, em 1964, viria a conspirar contra João Goulart e seria também cassado em 1966. Ao som de Raul Seixas, o filme apresenta o discurso de Adhemar de Barros: "Todos os sacrifícios devem ser implementados com ânimo forte quando a causa é boa. Nunca deixamos de defender os humildes, os pequeninos [...] Somente a fé nos trouxe de volta a esta casa $[\ldots] "$.

Esses personagens que retornam e se atualizam constantemente na história do Brasil fazem ecoar a máxima marxiana quando d'O 18 de Brumário de Luís Bonaparte: "A história se repete, a primeira vez como tragédia e a segunda como farsa". Andréa França ressalta a abertura que a constante justaposição de heterogeneidades em Jânio a 24 Quadros promove nos sentidos unívocos de determinado evento histórico:

O acontecimento da política não é determinado por causas, diz o filme, mas premido por sua grotesca e caricata iminência; não é um rio mas um labirinto, tampouco é um círculo, mas um turbilhão em espiral. E a montagem, ao religar imagens e sons distantes no tempo e no espaço, investiga a história política não como sucessão de acontecimentos (o tempo como cronologia) 
mas como aquilo que "retorna" 125 .

De fato, no caleidoscópio de imagens e sons de Jânio a 24 Quadros, farsa e tragédia caminham lado a lado em espiral. E, portanto, "profanar o tempo", nas palavras de Gal, é precisamente o gesto central de seu filme. O passado, representado pelos arquivos de que o filme se vale, passa incessantemente pelo processo de collage, numa constante dialética entre fragmentação e (re)junção.

Se a collage evoca, por exclusão - e recusa, portanto, por definição -, o mundo codificado, ela impõe, por justaposição e, portanto, por síntese -, a releitura de tal mundo. Isso porque a síntese proposta pela collage não é um fim em si mesma, mas incita a desmembramentos infinitos, que são as possibilidades de reler o mundo ${ }^{126}$.

"Que eu me organizando posso desorganizar; Que eu desorganizando posso me organizar", diria Chico Science. Reler o mundo, como sabemos, é um gesto que se dá essencialmente no presente. Dessa forma, a leitura que Jânio a 24 quadros nos oferece do Brasil é por possibilidades, sobretudo novas e originais possiblidades na atualidade de sua rejunção. Não à toa, Gal insere várias músicas que sua geração ouvia, como Janis Joplin, Mutantes, Wilson Simonal, assinalando que o seu tempo, a seu modo, tomava partido na assincrônica história nacional.

O processo de collage ocorre de forma potente na sequência que se inicia com uma entrevista do Comandante do II Exército, General Dilermando Gomes Monteiro, arguindo que o Brasil, em fins dos anos 70, não vivia nenhum aspecto de golpe militar. Corte para imagens de dois outdoors: um em apoio à candidatura do General Figueiredo, exibindo sua foto e, a seu lado, uma propaganda da cachaça 51 "Eleita pelo povo". Em seguida, vemos alguns homens comendo em um restaurante popular indiferentes à TV, que exibia a posse de Figueiredo. Fechando essa sequência, ouvimos um trecho do discurso do general eleito junto a uma inusitada capa de revista que, em meio a outras de fofoca, o exibia sem camisa fazendo exercícios físicos.

\footnotetext{
${ }^{125}$ FRANÇA, 2015, p. 58.

${ }^{126}$ FLUSSER apud COHEN, 1989, p. 64.
} 

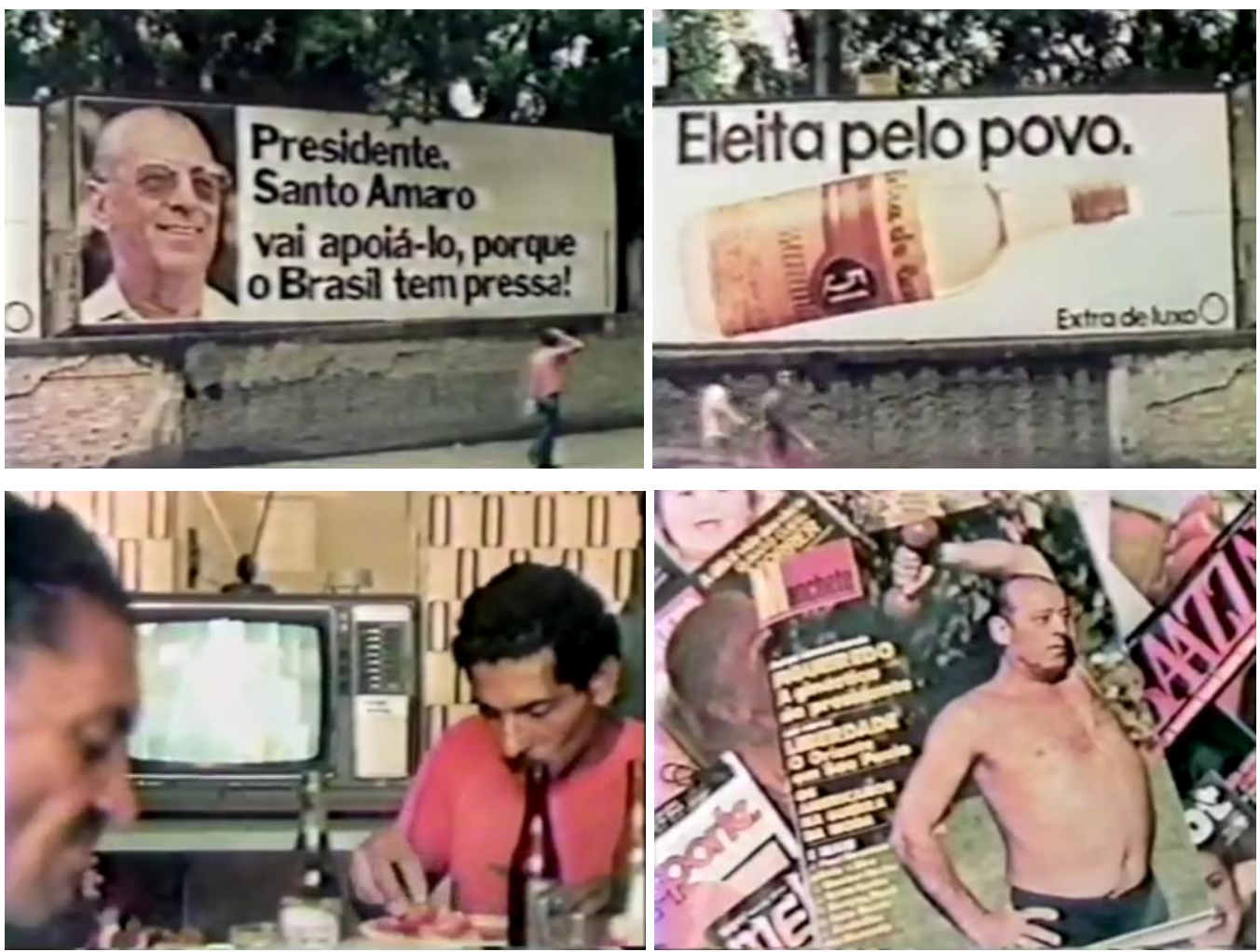

Fig.33. A sequência sobre a eleição de Figueiredo.

Com essa sequência podemos refletir, por exemplo, sobre a imagem da ditadura, regime marcadamente autoritário, naturalizada em meio a bens de consumo comercializados pela propaganda de massa. Onde se distingue, no fetichismo do mercado, o sisudo general Figueiredo da popular cachaça 51? São ambos eleitos pelo povo? Como a publicidade atuou de forma a legitimar a ditadura? E o trabalhador comum, sufocado durante anos de arrocho e repressão, que representatividade a eleição indireta daquele general lhe trazia? É a farsa do espetáculo da política que atravessa o filme, onde "chacretes" e "figueiredos" conformam a mesma obscenidade encarnada na "família brasileira". Mais uma vez, recorro à preciosa leitura de Andréa França sobre o filme:

O procedimento de pôr elementos distintos em relação produz no seio do acontecimento da ditadura novas afinidades e oposições, de modo a acionar outros sentidos que são irredutíveis à soma de suas partes. [...] a montagem de imagens da política como mero espetáculo e puro entretenimento é um gesto efetivamente político porque reúne o que estava apartado, de modo a devolver ao espectador a possibilidade de experimentar as imagens como elementos a serem comparados, associados, confrontados, interrompidos. Não se trata de reiterar a tese da estetização da política como catástrofe mas, e essa é a 
atualidade do gesto do montador/cineasta, como chanchada, teatro de revista, programa de auditório ${ }^{127}$.

O Brasil como uma grande chanchada, incluindo obviamente todo o conteúdo pornográfico que ela carrega. Não por acaso, após vermos mais uma entrevista peculiar de Jânio Quadros, na qual ele dizia que tudo que desejava era “[...] o estabelecimento, em nosso país, de um regime democrático autêntico. E... Para mim, um regime democrático autêntico é um regime democrático autoritário, forte. Porque... as coisas não são contradição em termos [...]"; a seguir, somos convidados, ao som de Mania de você (Rita Lee), a assistir a sucessivas capas de jornais evidenciando casos de conflitos no Congresso Nacional, a repressão da ditadura, querelas entre partidos políticos, as negociatas nos bastidores pela transição, onde os personagens mais sóbrios (ex: Tancredo Neves) e também os mais vulgares (ex: Paulo Maluf) compunham o mesmo jogo político.
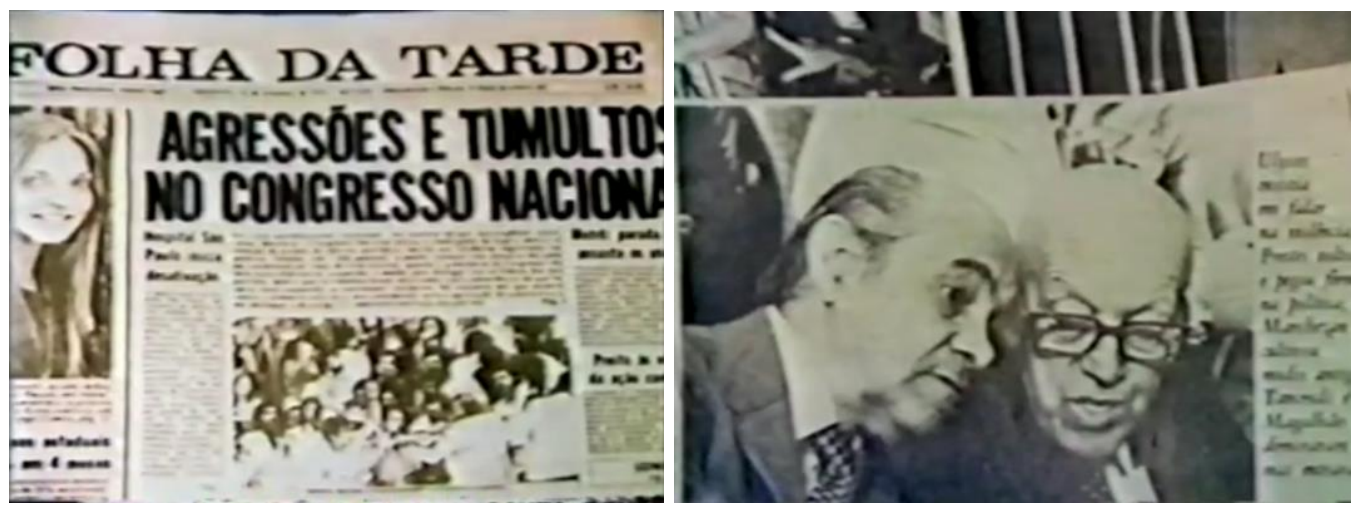

Fig.34. Os arquivos dessacralizados em Jânio a 24 Quadros.

Jânio a 24 Quadros, portanto, literalmente "escrachava" o paradoxo de um Brasil tão exposto em programas de auditório, revistas, na própria pornochanchada, mas, ao mesmo tempo, tão recalcado na sobriedade oficial e na "família brasileira", paradoxo que talvez ninguém tenha explorado melhor que Nelson Rodrigues. Na sequência final do filme, propositadamente fora de sincronia, é exibida uma entrevista de Jânio ao jornalista Almir Guimarães, no programa Pinga-Fogo (TV Tupi). Contestado pelo jornalista por sua renúncia à presidência, vemos Jânio exaltado e a montagem do documentário, alternando sucessivos primeiros planos da entrevista e as próprias falas editadas, estilhaça

${ }^{127}$ FRANÇA, 2015, p. 63. 
qualquer possibilidade de síntese e coerência daquela situação, desmembrando, através de Jânio, a própria leitura do país em infinitas possibilidades. Não por acaso, através de uma câmera intencionalmente tremida, sacudida mesmo, somos conduzidos ao encerramento do filme nos arredores do Palácio do Planalto.

Resultam estilhaçados, ambos, a história nacional e a sobriedade documental. O "fato novo" observado por José Carlos Avellar em Mato eles?, por outros caminhos, também foi apontado à época por críticos acerca de Jânio a 24 Quadros. Destaco a crítica feita por Jairo Ferreira, na qual ele explicita a distinção geracional:

[...] o jovem realizador Luiz Alberto Pereira (o popular Gal) [...] amplia consideravelmente a área/forma de trabalhar o documental, sem o didatismo convencional, o ranço e a chatice de outros exemplares recentes ou não. [...] A comparação é inevitável: $O s$ anos $J K$, de Sílvio Tendler, é bom, porém chato; Jânio a 24 quadros é bom e divertido [... $]^{128}$.

Fica perceptível, em críticas como a de Jairo Ferreira e a de Avellar, que as transformações trazidas por esses dois documentários revigoravam a estética do documentário nacional, desgastado pela hegemonia da sobriedade nas décadas anteriores. O escape ao didatismo, conforme assinalado acima, era uma forma de provocar e valorizar a inteligência do espectador em produzir suas próprias sínteses. Embora sarcástico, debochado, o filme de Luiz Alberto Pereira enuncia uma política potencialmente mais "séria" que a de muitos documentários permeados pela impressão de objetividade, afinal, como já sinalizado por cineastas das mais variadas escolas (ex: Jean-Luc Godard, Luis Buñuel, Dziga Vertov, Glauber Rocha, Eduardo Coutinho) a forma do filme é centralmente política.

\section{3.}

\section{Mato eles?: quem mata?}

No recente documentário Martírio (2016), o diretor Vincent Carelli levanta a reflexão de que a melhor forma de se compreender conjunturalmente o Brasil é observando a forma como a "questão indígena" tem sido tratada em cada período. No entanto, atravessando boa parte da história do país através dos Guaranis-

${ }^{128}$ FERREIRA, Jairo. "Documentário na trilha da chanchada". Filme Cultura, n. 41, 1983. 
Kaiowás, fica patente, em seu filme, a incapacidade dos mais variados governos em lidar com os originários dessa terra, que seguem marginalizados e em processo de aniquilação.

Em Mato eles? ${ }^{129}$ o ataque aos discursos de sobriedade não se inscreve apenas em seu texto, conforma também um de seus argumentos centrais. A interrogação levantada em seu título atravessa todo o filme, no qual somos convidados a refletir sobre o trágico destino desses povos em um país que, desde a sua gênese, tem buscado olhar mais para fora que para dentro, tornar-se o "Brasil grande" e civilizado para ser aceito pelo mundo ocidental. Como bem sublinhado por José Carlos Avellar, o extermínio indígena é uma questão dos brancos, não dos índios ${ }^{130}$.

Mato eles? aborda a implantação de uma madeireira em Mangueirinha, sudoeste do Paraná, em meio a uma reserva habitada por indígenas Kaingangs, Guaranis e o último remanescente dos Xetás. Toda a articulação do filme de Bianchi se orienta a ressaltá-lo como uma forma de intervenção direta no real, suscitando questionamentos sobre a história daquela reserva indígena e, centralmente, sobre a política de representação na qual se inscreve sua realização. Embora o documentário claramente se posicione a favor da causa indígena, prevalece antes o elemento formal da enunciação ao enunciado. Em outras palavras, o argumento é a própria desconstrução da representação dos indígenas, a nível geral, pelos "brancos", a nível particular, pelas imagens documentais. De forma similar a Jânio a 24 quadros, várias portas são abertas, mas nenhuma é fechada.

Ironia, sarcasmo, esses são os componentes principais de que se vale Bianchi como forma de expressar o absurdo daquela história na própria forma fílmica. Logo no começo de Mato eles?, vemos Dom Albano Cavallin (Bispo Auxiliar de

\footnotetext{
${ }^{129}$ Além da já mencionada menção no Festival É Tudo Verdade, Mato eles?, um dos filmes de maior repercussão analisados neste trabalho, ganhou os seguintes prêmios: Prêmio do Júri Popular de Melhor Curta e de Melhor Roteiro no Festival de Brasília (1983); Prêmio São Saruê de Melhor Curta da Federação de Cineclubes do Rio de Janeiro (1983); Prêmio do Instituto Indigenista no Festival Latino-americano de Povos Indígenas (1985); Melhor Direção no Festival de Gramado, Rio Grande do Sul (1983).

${ }^{130}$ AVELLAR, José Carlos. “'Mato eles?' e 'Chapeleiros' - a arte de fazer perguntas”. Jornal do Brasil, 06/12/1983.
} 
Curitiba) numa escadaria em contra-plongée ${ }^{131}$. Em tom marcadamente sarcástico, Bianchi lhe pergunta:

Dom Albano Cavallin, não querendo ser chato, dizem que os primeiros navios que chegaram aqui, vinham padres também. E esses padres ajoelhavam os índios e davam uma Bíblia para eles lerem. Se os índios entendessem o que queria dizer, tudo bem. Se não entendessem, cortavam a cabeça na hora deles.

O "não querendo ser chato" e o "dizem", acrescidos do tom sarcástico da voz do diretor, naturalmente, deslocam o filme da sobriedade usual que a tradição documental estipulou tanto na narração quanto na forma de entrevistar o outro. A resposta de Dom Albano Cavallin, inserida na composição farsesca da cena, surge como a própria síntese carregada do cinismo contido no título do filme:

\begin{abstract}
A Igreja é uma mãe. Eu penso que, se todos pais fizerem uma análise de sua educação, eles vão encontrar alguns problemas educacionais. Pode ter acontecido, mas a grande história de Anchieta, Nóbrega, Vieira, até os padres que no momento estão morrendo em determinadas reservas indígenas, hoje, com seus nomes depredados, esses homens estão mostrando que a Igreja, cada vez mais, quer ser uma educadora, com enorme respeito ao índio. E o grande lema de 1982, para a Igreja no Brasil, será este "Paz e Terra aos Povos Indígenas" [...] "O Índio, aquele que deve viver".
\end{abstract}

Ao fim de seu discurso, Dom Albano Cavallin sorri largamente e é inserido um tumultuado som extradiegético como uma espécie de aplausos que contrastam com duas imagens de um índio: uma de seus olhos, a outra, de sua boca fechada. O farsesco é utilizado no filme como forma de evidenciar o cinismo de alguns discursos naturalizados na sociedade que vêm a legitimar o extermínio indígena. O mais marcante consiste na fala da caricatural grã-fina que, em um ambiente suntuoso, não compreendia por que os indígenas teimavam em resistir, apontando, de modo debochado, que "[...] nem tem terra, nem tem lugar, não tem o que fazer. Não existe política de integração. Ou eles se aculturam ou morrem. E é o que está acontecendo: estão morrendo".

\footnotetext{
${ }^{131}$ Enquadramento em que a câmera se coloca abaixo do nível dos olhos da pessoa filmada e, portanto, situando-a acima do espectador.
} 

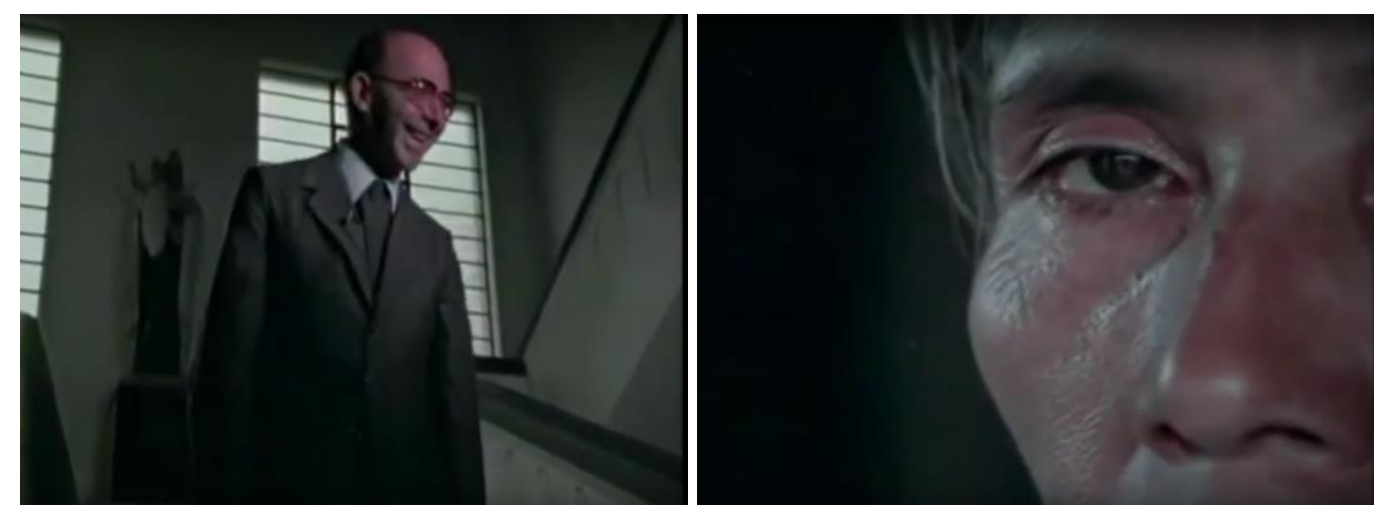

Fig.35. Sequência de abertura de Mato eles?.

O documentário parte da morte do cacique Kangang Ângelo Cretâ, através de uma emboscada feita por fazendeiros locais, e da constatação do último remanescente dos Xetás naquela reserva como sintomas da extinção indígena. Após a sequência inicial, vemos a imagem de um índio manuseando uma espingarda acompanhada da seguinte narração: “[...] Em janeiro de 1980, o cacique Kangang Ângelo Cretâ foi emboscado. 3 inquéritos foram instaurados, 2 deles foram arquivados e, até hoje, não foi identificado nenhum culpado". Mato eles?, então, percorre alguns relatos sobre a morte do cacique e, em seguida, somos convocados a tomar parte no filme através de um dos principais recursos formais de que se vale em sua narrativa: os letreiros.

Mecanismo largamente utilizado pelo campo documental a fim de apresentar algum dado, contextualizar, assinalar alguma informação importante, em Mato eles? os letreiros se revelam, de forma irônica, como uma questão de múltipla escolha. Tomando como princípio que o cacique foi emboscado, o filme nos convida a equacionar a morosidade da Justiça através de uma série de possibilidades, entre elas "nenhuma das respostas anteriores". Sobretudo as respostas “(b) os magistrados teriam interesses econômicos na não resolução do caso" e "(d) foi um acidente de trânsito normal”, articulam uma ácida ironia tanto sobre o silenciamento que paira sobre a questão indígena quanto na banalização com que determinados casos são "resolvidos"132.

\footnotetext{
${ }^{132}$ Importante ressaltar que esta situação remete também à condição dos camponeses de Terra para Rose, quando sabemos da morte da protagonista do filme e da decorrente não resolução do crime.
} 
A utilização desses letreiros é, certamente, um convite à tomada de posição do espectador, porém, distante da tradição dos documentários sobre questões sociais, o filme de Bianchi o faz não a nível de denúncia ou atestação de um argumento. A própria desarticulação da lógica marcadamente objetiva que pauta as questões de múltipla escolha é expressiva do caminho reflexivo e irônico assumido pelo filme. Mato eles? se vale da intervenção direta de vários artifícios visuais e sonoros como forma de provocar o espectador e abrir a história. Aproxima-se, desse modo, de um filme como Congo, subvertendo mecanismos clássicos da linguagem documental sóbria, como os letreiros que, tanto no filme de Arthur Omar quanto no de Bianchi, propõem "ao espectador um trabalho de concatenação, em que nada é garantido"133.

Embora a morte do cacique aponte para a repressão contínua que os índios têm sofrido pelas classes dominantes, a política do filme de Bianchi se desloca para as sutilezas dos que, aparentemente, estariam do lado da causa indígena: por um lado, a própria Fundação Nacional do Índio (Funai, em tese, um órgão de proteção indígena), por outro, as representações dos índios através dos discursos de sobriedade. Nesse sentido, João Luiz Vieira assinala os letreiros do filme de Bianchi como um mecanismo que vem a perturbar as debilidades de posições humanistas e politicamente engajadas em tomar esse outro (indígena) de forma não fetichizada ou condescendente:

[...] O brechtianismo dessas questões, no seu pedido implícito de colaboração do espectador e de consequente "formulação de um veredito" é carregado de uma ironia mordaz, uma vez que nas questões e respostas propostas há sempre uma tendência à contradição e ao absurdo. [...] Questões e respostas criam um espaço bastante desconfortável para o espectador progressista e educado nos valores humanitários, ao confrontá-lo com a realidade do extermínio de uma maneira que, inicialmente, pode provocar um sorriso desconfiado e sem jeito mas que, em seguida, suscita a reflexão e o questionamento ${ }^{134}$.

A seguir, Mato eles? investe contra as representações cientificistas dos indígenas através de uma simulação dos chamados travelogues, em uma abertura épica intitulada $O$ Último Xetá, acompanhada da música $O$ Guarani (Carlos

\footnotetext{
${ }^{133}$ DA-RIN, 2004, p. 189.

${ }^{134}$ VIEIRA, 2004, p. 102.
} 
Gomes). O Último Xetá começa com a "descoberta", na década de 50, de índios Xetás, até então, sem contato com a "civilização". Vemos imagens costumeiras do cotidiano daqueles índios acompanhadas da narração onisciente de Arnaldo Jabor que, em tom sóbrio e excêntrico, detalhava o modo de vida daquela comunidade. Ao surgir a imagem do "último Xetá", Jabor nos diz, por exemplo: “[...] Crianças e homens usam esses ornatos auriculares de pena. Nosso jovem guia índio reencontra com prazer os adornos do passado". 25 anos depois, a situação exibida é a própria constatação da tragédia. Vemos "o último Xetá" parado em frente à câmera, sem proferir uma palavra, sendo enquadrado pelo diretor de Mato eles? João Luiz Vieira percebe uma fina ironia nessas imagens, construídas de modo a atualizar o massacre dos "heróis" mitificados do passado na naturalização de um presente desolado, no qual os índios passaram a ser criminalizados ${ }^{135}$ :

A música romântica da ópera de Carlos Gomes $O$ Guarani soa celebratória na trilha sonora, criando expectativas de um espetáculo épico-heroico. As imagens que se seguem, contudo, rompem radicalmente com as pretensões épicas tanto do título quanto da abertura musical. O que vemos é apenas o único sobrevivente da tribo, literalmente o "último dos Xetás", apresentado numa série de fotografias (frontal, perfil esquerdo, perfil direito) que carrega reminiscências das fichas policiais. O bravo guerreiro do romantismo é agora o desprezado e manipulável objeto do discurso oficial das fotos de polícia que friamente registram o homicídio ${ }^{136}$.
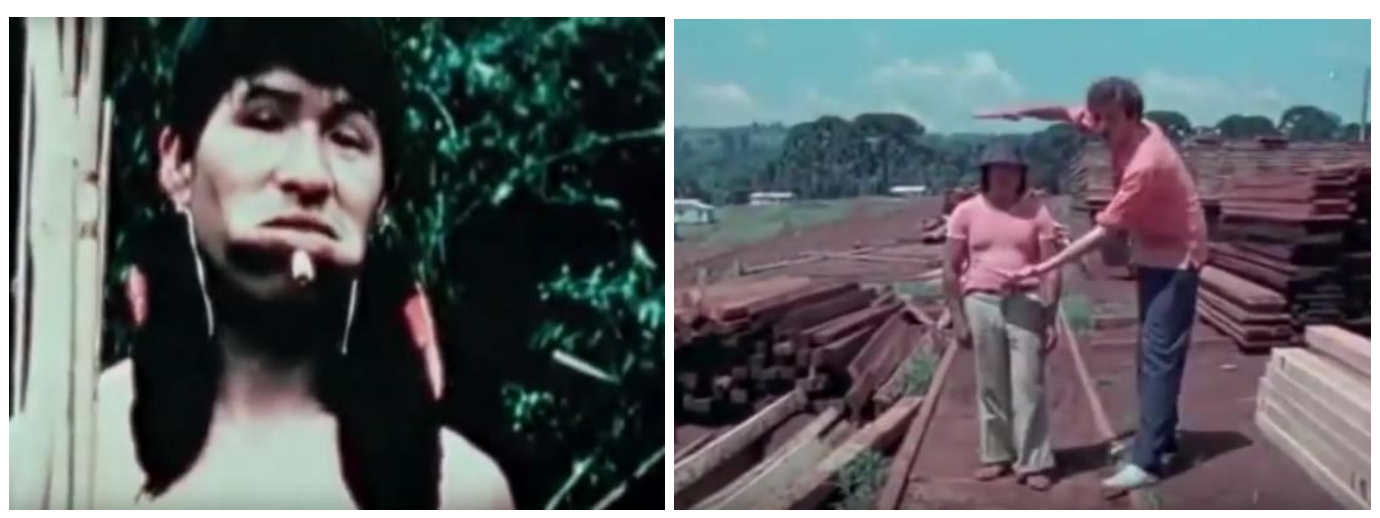

Fig.36. O último Xetá.

${ }^{135}$ Largamente disseminado na sociedade brasileira, o discurso de criminalização das comunidades indígenas pode ser percebido, claramente, no filme Corumbiara (2009, Vincent Carelli).

136 VIEIRA, 2004, p. 103. 
Em seguida, vemos um clipe com imagens da tribo dos Guaranis. Aqui, não há qualquer narração. Apenas a contundente trilha sonora d'O Guarani (Carlos Gomes) junto a imagens dos índios na mata com um ar perdido frente à câmera que os percorre, outros na beira da estrada, alguns planos de seus artesanatos. Se, conforme observamos, alguns filmes do capítulo 01 colocavam a questão da sobreexposição das imagens, Mato eles? se dirige justamente ao outro pólo dialético, a superexposição:

[...] quando as imagens convocam "naturalmente" as palavras que devem acompanhá-las, ou quando as palavras convocam "espontaneamente" imagens que lhes correspondam, podemos dizer que estas últimas - como aquelas - foram reduzidas a uma bobagem de mínimo valor: a estereótipos. ${ }^{137}$

Nesse sentido, de modo similar a Luis Buñuel em Terra sem Pão (1932) ${ }^{138}$, Mato eles? produz reflexões através da dissonância entre as imagens e a narração objetiva, acrescidas, no filme de Bianchi, de uma potente montagem sonora. Investe-se, centralmente, na implosão da lógica de representação do exótico, lógica esta que é sugerida como cúmplice da barbárie indígena. Sergio Bianchi chamaria seu método de um "estilo da possibilidade", ao explorar o material produzido com encenações e intervenções na montagem voltados à imprevisibilidade $^{139}$.

A outra reflexão que o filme articula consiste no papel da Funai. Boa parte da reserva florestal, da qual os índios foram retirados, era alvo de uma disputa judicial envolvendo a F. Slaviero e Filhos S.A. e a própria Funai. Na outra parte da reserva, onde viviam os Kaingangs, a Funai implantou uma serraria com intuito de cortar somente as árvores desvitalizadas ou inúteis. Os índios se tornaram, assim, assalariados dentro de uma madeireira gerida pela própria Funai.

\footnotetext{
${ }^{137}$ DIDI-HUBERMAN, 2014, p. 16, tradução nossa.

${ }^{138}$ Em Terra sem Pão, Buñuel opera um verdadeiro curto-circuito entre as imagens que vemos e o texto narrado acentuadamente objetivo, ressaltando, gradativa e sensivelmente, que o filme se trata de uma crítica às formas de representação dos povos no cinema e na sociedade de modo mais amplo. Segundo Nichols: “[...] Talvez os comentários e julgamentos do filme sejam uma caricatura do tipo de comentário encontrado tanto nos travelogues da época como entre muitos espectadores potenciais desse tipo de filme naquele tempo. Talvez Buñuel esteja satirizando uma forma de representação que usa dados documentais para reforçar estereótipos preexistentes. Terra sem pão, de seu ponto de vista, pode ser um filme sumamente político, que questiona a própria ética do cinema documentário".

139 "Segunda entrevista" de Bianchi por João Luiz Vieira (VIEIRA, 2004, p. 59-89).
} 
Paradoxo? Pois é exatamente o que Mato eles? vasculha. Em várias entrevistas, a mesma pergunta proferida por Bianchi passa a ecoar: "E quando acabarem as árvores, o que o índio vai fazer?" Um trabalhador da serraria responde: "Quando acabar a madeira, o índio vai ficar olhando um pra cara do outro".

Mais à frente, Sergio Bianchi discute com um funcionário da Funai, lançandolhe uma série de questionamentos contundentes que são respondidos de forma protocolar: "O lucro da serraria vai pra onde? [...] Eu não entendi a lógica de uma serraria da Funai dentro de uma reserva indígena [...] A comunidade indígena não é gerenciada pelos índios, é gerenciada pela burocracia da Funai [...]”. Essa forma de entrevista, muito mais próxima de uma inquirição, pouco se preocupa com a exposição objetiva dos fatos ou qualquer pretensão de imparcialidade. A produção de sentidos decorre da discussão, por vezes mais exaltada, entre Bianchi e o funcionário do governo. Como forma de enfatizar ainda mais o absurdo detectado com o assalariamento dos índios pela Funai, em seguida vemos novamente os letreiros característicos do filme.

Assinale a alternativa correta:

O lucro adquirido na extraçcão da madeira e da lavoura tem a seguinte destinação: a) Vai para Curitiba e volta, sendo aplicado exclusivamente dentro da área indigena. b) $O$ dinheiro é remetido para 0 exterior, pois a Funai é uma empresa extratora de madeira. tazendo parte de um conglomerado internacional. c) A Funai é um órgão de proteção e o dinheiro é retido numa conta bancária especial em nome dos indios, até que eles atinjam uma maioridade intelectual. d) Os assalariados da serraria não são indios, sc̃o emigrantes orientais. e) $O$ dinheiro se perde no percurso dos canais burocráticos.

Fig.37. As questões de múltipla escolha em Mato eles?. 
Por fim, chegamos à comunidade dos Kaingangs, momento no qual a voz sempre dominante do diretor se vê abalada. O primeiro índio que vemos diz a Bianchi que a Funai não respeitava o acordo feito e que eles estavam revoltados com a destruição da reserva. Bianchi, mais uma vez, pergunta sobre o que aconteceria quando acabasse a madeira. O índio, de forma categórica, lhe responde que eles se tornariam mendigos. Após ouvir outros índios que também criticavam a Funai e afirmavam sua postura de resistência, o último índio entrevistado relata que seu avô comprara aquelas terras diretamente de Dom Pedro II. E, quebrando os lugares ocupados por diretor e entrevistados, em meio a uma reclamação sobre quererem fazê-los de bobo, o índio devolve a ironia que marcara todo o filme ao se virar para Bianchi e lhe perguntar: "E o senhor, quanto o senhor ganha? Quanto o senhor ganha?”. O índio, sempre subjugado e visto como o "outro", tomava a voz do filme para si e colocava o diretor, ali um representante dos "brancos", em posição acuada.

Essa desestabilização gera um curto-circuito no filme, pois o próprio diretor passa a compartilhar das ironias que havia proporcionado ao espectador. A narração que encerra Mato eles? é marcante da inscrição de todos, diretor e espectadores, da direita mais reacionária à esquerda progressista, na tragédia indígena:

Aproveita, cara. Aproveita que tá acabando. Escuta, se tiver parente do poder... vai lá e compra a terra, meu, tira a madeira. Dá uma grana, uma grana ótima. Aproveita. Compra a terra. Não tem dono, cara. Reserva não tem dono, aproveita. Se você é da oposição, faz um livro de fotografia, vai lá e fo-to-gra-fa. Fotografa. Faz um filme, cara. Você faz um filme e viaja para a Europa inteira com o filme, cara. A Europa quer ver essas coisas. O genocídio tá acontecendo agora. Não tá acontecendo agora o genocídio? Vai lá e fatura. Negocia. Pega alguns objetos que eles fazem, aqueles mais estranhos, e monta uma loja no centro do Rio, em São Paulo. No Rio não tem ainda. São Paulo tem. Monta uma loja. Vende. Turista europeu compra caro, cara. Olha, faz pesquisa. Tem pesquisa que pode ser feita. Linguística. Tem tribo com dois índios, cara. É uma puta transação para estudar. Faz pesquisa, pega uma bolsa de estudo e faz pós-graduação, meu. Outra forma é: você monta uma organização de defesa. Montando uma organização de defesa, você pega dinheiro da Holanda, da Bélgica e da Alemanha pra proteger. Você viu quantos documentários tem, cara, sobre índio? Mas o problema é que tem que ir rápido, cara, ta acabando! Porra, negocia, meu. 
$\mathrm{Na}$ implosão de signos e sentidos gerada no filme de Bianchi, as duas perguntas centrais que o atravessam ficam ecoando no próprio devir daqueles povos e do Brasil: “Quando acabarem as árvores, o que o índio vai fazer?”; e, então, "Mato eles?". A imagem do índio manuseando a espingarda que retorna ao fim do filme se revela sugestiva.

Fernão Ramos sinaliza um potencial problema em filmes como Mato eles? e Jânio a 24 Quadros. Ao mapear as principais teorias que refletiram sobre o campo documental, o autor define um campo chamado "cognitivista-analítico". Vinculado às teorias desconstrutivistas, suas formulações tendem a acentuar a auto-reflexividade na construção dos saberes e, em nível extremo, a incapacidade de qualquer grau de representação objetiva da realidade.

\begin{abstract}
Em geral, o discurso que tem na reflexividade seu ponto de fuga ético é sustentado pela negação da possibilidade de uma representação objetiva do real. Encontramos, no horizonte, novamente a preocupação do pensamento contemporâneo em frisar a fragmentação da subjetividade que sustenta a representação. A reflexividade, na realidade, é a saída, no vetor ético, do discurso que gira em volta do posicionamento subjetivo estilhaçad [...] Poderíamos dizer: o recuo reflexivo é o ponto cego ideológico da ideologia contemporânea. É o ponto cego onde a ideologia da ética contemporânea não consegue ver-se enquanto tal. Em outras palavras: é ético mostrar o processo de representação; não é ético construir a representação para sustentar a opinião correta (como defendiam Grierson, ou Eisenstein, em um outro parâmetro) ${ }^{140}$.
\end{abstract}

No entanto, conforme já sinalizei sobre o filme de Luiz Alberto Pereira, a negação de uma representação objetiva do real, tal qual no filme de Sergio Bianchi, produz significados por vezes muito mais potentes que em filmes direcionados à impressão de objetividade do real. São lacunas que se abrem através das disjunções das imagens, reverberando outras possibilidades de leitura da realidade. Podemos estabelecer uma comparação, sobretudo, com as formas mais complexas dos filmes do capítulo 2. Enquanto estes produzem enunciados através do polo positivo da dialética, em Mato eles? e Jânio a 24 Quadros, é através do polo negativo, da antítese reiterada que se geram outras sínteses mais abertas à "emancipação do espectador".

${ }^{140}$ RAMOS, 2001. 
Em perspectiva comparada, o movimento empreendido nos três primeiros capítulos deste trabalho revelam o desgaste da realidade brasileira enunciada de modo acabado, sóbrio, objetivo. Porém, é preciso reafirmar que o Brasil, com todas as tonalidades de leituras, continuava inscrito centralmente nesse conjunto de documentários. A seguir, trato de uma geração que sinalizava o próprio desgaste do pensamento sobre o país que se cristalizou na cinematografia dos anos 50,60 e 70. 


\section{4. \\ O vídeo anuncia os novos tempos}

4.1.

Uma geração olha o mundo

No livro Cinema, televisão e publicidade: cultura popular de massa no Brasil nos anos 1970-1980, José Mario Ortiz Ramos investiga a relação entre os três polos do audiovisual brasileiro nas décadas mencionadas. Em sua exposição, percebe-se a proeminência que a televisão, ao se conectar à publicidade ${ }^{141}$, conquistou no mercado audiovisual do país.

O cinema, marcado pela incipiência e a descontinuidade entre seus períodos de realizações mais importantes, foi paulatinamente sendo absorvido pela TV. Como nos mostra o autor, esse processo foi marcado por um intenso choque ideológico entre um cinema que se propunha mais "artesanal”, através do próprio lema "Uma câmera na mão e uma ideia na cabeça", e a lógica de produção industrial que a TV pressupunha. Verifica-se, em diversos realizadores, uma profunda ambiguidade sobre ser ou não incorporado ao mundo televisivo ${ }^{142}$.

Contudo, após a consolidação da TV e a introdução do vídeo no Brasil durante os anos 70, alguns autores percebem uma nova geração "não contaminada" pela "brasilidade romântico-revolucionária" que Marcelo Ridenti observou na intelectualidade engajada dos anos 50 e $60^{143}$. Mapeando as origens do vídeo no Brasil, Arlindo Machado assinala que, após uma primeira geração de videastas que produziram vídeo tapes na década de 70 vinculados às galerias de arte, nos

\footnotetext{
${ }^{141}$ De acordo com o autor, ao contrário de alguns países europeus onde o Estado tinha ingerência regulatória sobre a veiculação televisiva, a grande inovação da TV Globo se deveu a sua íntima conexão com o mundo publicitário, aplicando o sistema de venda de tempo de comercial por audiência, no qual se "explicitava a lógica econômica da televisão, mostrando que a audiência constitui a sua "forma mercadoria"” (RAMOS, 2004, p. 43).

142 José Mario Ortiz Ramos apresenta uma série de posicionamentos dos cineastas da geração dos anos 50 e 60 sobre seu controverso relacionamento com a TV (RAMOS, 2004).

${ }^{143}$ A estrutura de sentimento da brasilidade (romântico-)revolucionária assinalada por Ridenti demarca precisamente a busca de intelectuais e artistas por uma gênese, por um brasileiro mítico o camponês, o sertanejo, o negro - a fim de potencializá-lo como gérmen utópico da revolução brasileira. São apontados como exemplos expressivos dessa estrutura de sentimento: a trilogia clássica do início do Cinema Novo: Vidas secas, de Nelson Pereira dos Santos; Deus e o Diabo na terra do sol, de Glauber Rocha; e Os fuzis, de Ruy Guerra; a dramaturgia do Teatro de Arena de São Paulo; as produções dos Centros Populares de Cultura (CPCs) da União Nacional dos Estudantes, com atuações de figuras destacadas como Ferreira Gullar, e realizações como o filme Cinco vezes favela, dirigido por Leon Hirszman, Joaquim Pedro de Andrade, entre outros (RIDENTI, 2005).
} 
anos 80 surgiu uma nova geração renovando o campo no Brasil. Trata-se do grupo de jovens vinculados ao vídeo independente, que através das iniciativas da TVDO e do Olhar Eletrônico, “[...] buscavam explorar as possibilidades da televisão como um sistema expressivo, e transformar a imagem eletrônica num fato da cultura de nosso tempo"144.

Despontando nos anos 90, surgia uma outra geração que, em sua maioria, havia passado pelo ciclo anterior do vídeo independente. Arlindo Machado aponta em realizadores proeminentes dessa geração (Eder Santos, Sandra Kogut, Lucila Meirelles) [...] um certo afrouxamento das preocupações locais, a fixação em temáticas de interesse universal e um vínculo mais direto com a produção videográfica internacional" 145 .

Segundo José Mario Ortiz Ramos, surgia, então, uma nova geração composta por “'jovens' imersos na contemporaneidade audiovisual, marcados pela realidade do 'mercado' e afastados da tradição nacionalista presente no campo"146. Essa geração é marcada, fundamentalmente, pelo "trânsito intermídias", a própria síntese da fusão entre televisão, cinema e publicidade na linguagem do vídeo:

[...] um novo tipo de realizador, que só é possível devido ao atual estágio de modernização do audiovisual brasileiro. Programas de TV, longas, comerciais passam a ser concebidos como produtos audiovisuais e realizados por produtores que dominam as práticas nos três setores ${ }^{147}$.

O "afrouxamento das preocupações locais", isto é, uma perspectiva mais integrada e cosmopolita, junto ao trânsito intermídias, são duas tendências fundamentais do período. Não por acaso, os principais realizadores que se destacaram em fins dos 80 e na década de 90 iniciaram suas carreiras na publicidade e migraram para a televisão e o cinema: Beto Brant, Ugo Giorgetti, Walter Salles, João Moreira Salles, Fernando Meirelles, entre outros.

Nos anos 80, como forma de se diferenciar da TV Globo, a Rede Manchete decidiu priorizar sua audiência nas classes A e B, investindo em um jornalismo mais qualificado e na parceria com produtoras de vídeo independentes para a

\footnotetext{
${ }^{144}$ MACHADO, 2007, p. 18.

145 Ibidem, p. 19.

146 RAMOS, 2004, p. 94.

${ }^{147}$ Ibidem, p. 95.
} 
realização de programas, séries e documentários exclusivos ${ }^{148}$. Esse espaço aberto permitiu que alguns realizadores exercessem o trânsito intermídias. Por exemplo, os irmãos Salles que, através da sua produtora Videofilmes, contribuíram nessa busca de sofisticação dos programas televisivos da Rede Manchete através de algumas séries documentais ${ }^{149}$.

A seguir, analiso aspectos formais de Japão: uma viagem no tempo. Procuro compreender, através desse estudo de caso, como se deu nessa nova geração de cineastas brasileiros a relação do trânsito intermídias com o desejo de se conectar com o mundo moderno vislumbrado além das fronteiras nacionais.

\section{2.}

\section{Japão: uma viagem no tempo: o presente na superfície}

A série documental Japão: uma viagem no tempo (1986, Walter Salles) foi exibida em quatro episódios (O Outro Lado do Mundo; Os Samurais da Economia; Os Novos Criadores; Kurosawa, Pintor de Imagens). Embora possam ser vistos autonomamente, o argumento em torno da relação entre a modernidade e as tradições japonesas os une, criando uma organicidade que é melhor apreendida em seu conjunto. Vários aspectos atravessam toda a série, como a moda, a música, a arquitetura, os costumes, a computadorização e, sobretudo, a proliferação de imagens da sociedade japonesa.

Em O Outro Lado do Mundo prevalece um tom de descoberta, de puro fascínio com "a imensa colagem de imagens", segundo a narração de José Wilker, que Tóquio revelava: “[...] diversidade, velocidade, criatividade. O cenário parece diretamente tirado de um filme de ficção científica, mas aqui tudo é real [...]”.

\footnotetext{
${ }^{148}$ FECHINE (2007); FRANÇA (2018).

${ }^{149}$ Como já mencionado na introdução, outras séries se inserem nesse mesmo contexto, como China, o Império do Centro (1987, série de cinco episódios) e América (1989, série de cinco episódios), dirigidas por João Moreira Salles, African Pop (1989, série de cinco episódios), de Belisário Franca, Xingu - a terra mágica dos índios (1985, série de onze episódios), de Washington Novaes. Em entrevista concedida à Andréa França, o depoimento de Marcelo Dantas, produtor cultural, é precioso sobre a atmosfera dessa época: “[...] o mundo tinha mudado, a gente estava abrindo a economia, a gente estava abrindo os vasos comunicantes, a gente queria ver outra coisa [...] O Amaral Neto, o repórter, já tinha feito o Brasil. O Brasil não estava fora da televisão, o Brasil estava bem dentro da televisão [...] Amaral Neto, o repórter, é brilhante, com toda a canalhice dele, ele filmou, mostrou para o Brasil a cara que o Brasil tinha [...] O que eu quero dizer é que você achava o Brasil no ar, você não achava o mundo, porque a televisão brasileira não tinha fôlego de ir ao mundo e então a gente, no Brasil, tinha uma curiosidade, quando abriu, a gente queria ver tudo o que vinha de fora." (FRANÇA, 2018 p. 82-83).
} 
Desse modo, há um constante arrebatamento pela metrópole, por todas as idiossincrasias que a sociedade japonesa apresentava naquele momento, repleta de luzes, letreiros, neons, o trem-bala shinkansen a céu aberto, multidões apinhadas nos metrôs. Acompanhando o tom embasbacado do filme com o modo de vida nipônico e suas constantes inovações, passamos por pessoas que dormem em cápsulas para evitar o ir e vir diário de suas casas ao trabalho, crianças que aprendem em suas escolas através de microcomputadores, diversos arranha-céus, taxistas que usam luvas por higiene, luzes e mais luzes. A sensação do primeiro episódio remete ao itabirano de Carlos Drummond de Andrade ${ }^{150}$ que descobre a grande cidade, porém, no caso da série, sem apresentar a nostalgia de sua terra.

Nos outros três episódios, ocorre uma constante alternância entre o polo ultramoderno e o polo tradicional da cultura japonesa: jovens que copiam a cultura ocidental e se juntam para dançar como os astros do rock e o teatro nô; templos milenares e construções pós-modernas; os videoclipes de péssima qualidade, segundo a própria narração do documentário, e a arte da caligrafia; os grandes centros comerciais poluídos de imagens e o templo zen.

Ao contrário da série African Pop (1989), inscrita no mesmo contexto de internacionalização do audiovisual brasileiro pela TV Manchete, na qual Andréa França assinala a aproximação com a linguagem "estilo MTV"151, em Japão: uma viagem no tempo prevalece um tom observativo, através de planos-fixos e panorâmicas que revelam a imensidão dos arranha-céus, as multidões em constante movimento e, sobretudo, a inundação de imagens por todo lado. Não obstante, por vezes, a câmera oscila entre movimentos mais soltos (travellings, zooms, chicotes) quando misturada aos elementos mais dinâmicos do cenário japonês, e planos fixos e lentas panorâmicas quando retrata o polo tradicional, enfatizando o seu traço meditativo. Essa situação pode ser observada em um dos tantos contrastes que o documentário aponta. No fim do primeiro episódio, a câmera se coloca bastante fluida em meio aos jovens que dançam Takenoko (um híbrido de vários estilos musicais) nas ruas de Tóquio. Logo em seguida, através de planos-fixos e detalhes, o documentário apresenta o preparo do chá através de Yoshimo, um jovem que segue a tradição milenar de seus antepassados.

\footnotetext{
${ }^{150}$ Confidência do Itabirano (Carlos Drummond de Andrade).

${ }^{151}$ FRANÇA, 2018.
} 
Junto às imagens, somos guiados pela onisciente narração de José Wilker a percorrer os mais variados aspectos da cultura nipônica. É preciso ressaltar que alguns recursos formais trazidos pelo vídeo são articulados de modo residual, sobretudo algumas imagens congeladas, que convidam a nos determos em algum aspecto observado em meio ao fluxo incessante de imagens.

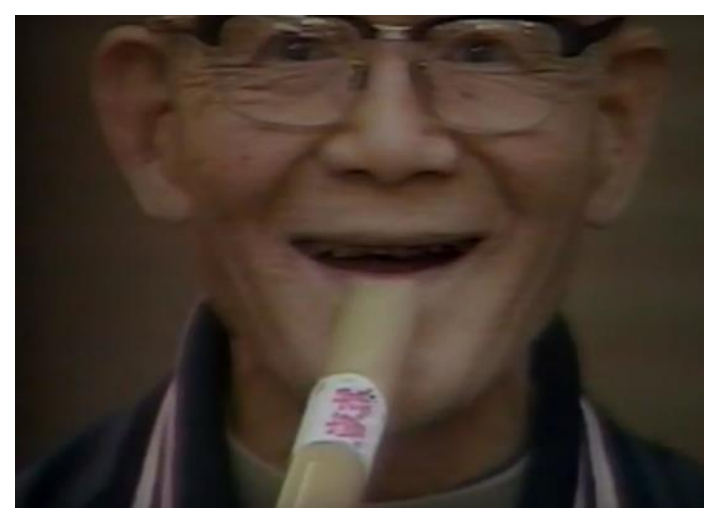

Fig.38. Imagem congelada de um japonês tocando sua flauta.

Japão: uma viagem no tempo se inseria num contexto de busca por "produtos com acabamento esmerado, que saibam unir o popular ao sofisticado e suportem uma versão falada em inglês" ${ }^{152}$. Nesse sentido, é reveladora a presença de alguns "filmes de arte" ao longo do documentário, como Contos da Lua Vaga (1953, Kenji Mizoguchi), A Balada de Narayama (1983, Shohei Imamura), Ran (1986, Akira Kurosawa), articulados na série fim de dialogar com o contexto observado na década de 80: a superpopulação, a ascensão social do país, o tema do suicídio. Assim, percebe-se uma tentativa de pôr o grande público da TV aberta em contato com obras de rara circulação, "unindo o popular ao sofisticado"153.

De forma mais profunda, inscreve-se o trânsito intermídias que a linguagem do vídeo busca e proporciona. Raymond Bellour assinala o vídeo através do conceito de "entre-imagens", um lugar de passagens das imagens do cinema, da televisão, da fotografia, da pintura, videoclipe, enfim das mais variadas imagens ${ }^{154}$ : "Entre-imagens diz respeito [...] a uma diversidade de experiências de hibridização, citações de um dispositivo por outro, e corresponde a um novo

\footnotetext{
152 "Walter Salles Jr. começa a filmar 'A Grande Arte' em novembro”, Folha de São Paulo, 23/09/1988

${ }^{153}$ Ibidem.

${ }^{154}$ BELLOUR, 1997.
} 
paradigma estético-cultural"155.

Por essa perspectiva, o vídeo ocupa um lócus atemporal onde as mais variadas imagens se cristalizam. Não por acaso, junto aos "filmes de arte" mencionados, no documentário de Walter Salles agregam-se imagens publicitárias, programas televisivos, videogames, computadores, animações, fotografias, gerando uma só imagem: “À noção de plano, espaço unitário e homogêneo, o vídeo prefere a de imagem, espaço multiplicável e heterogêneo"156.
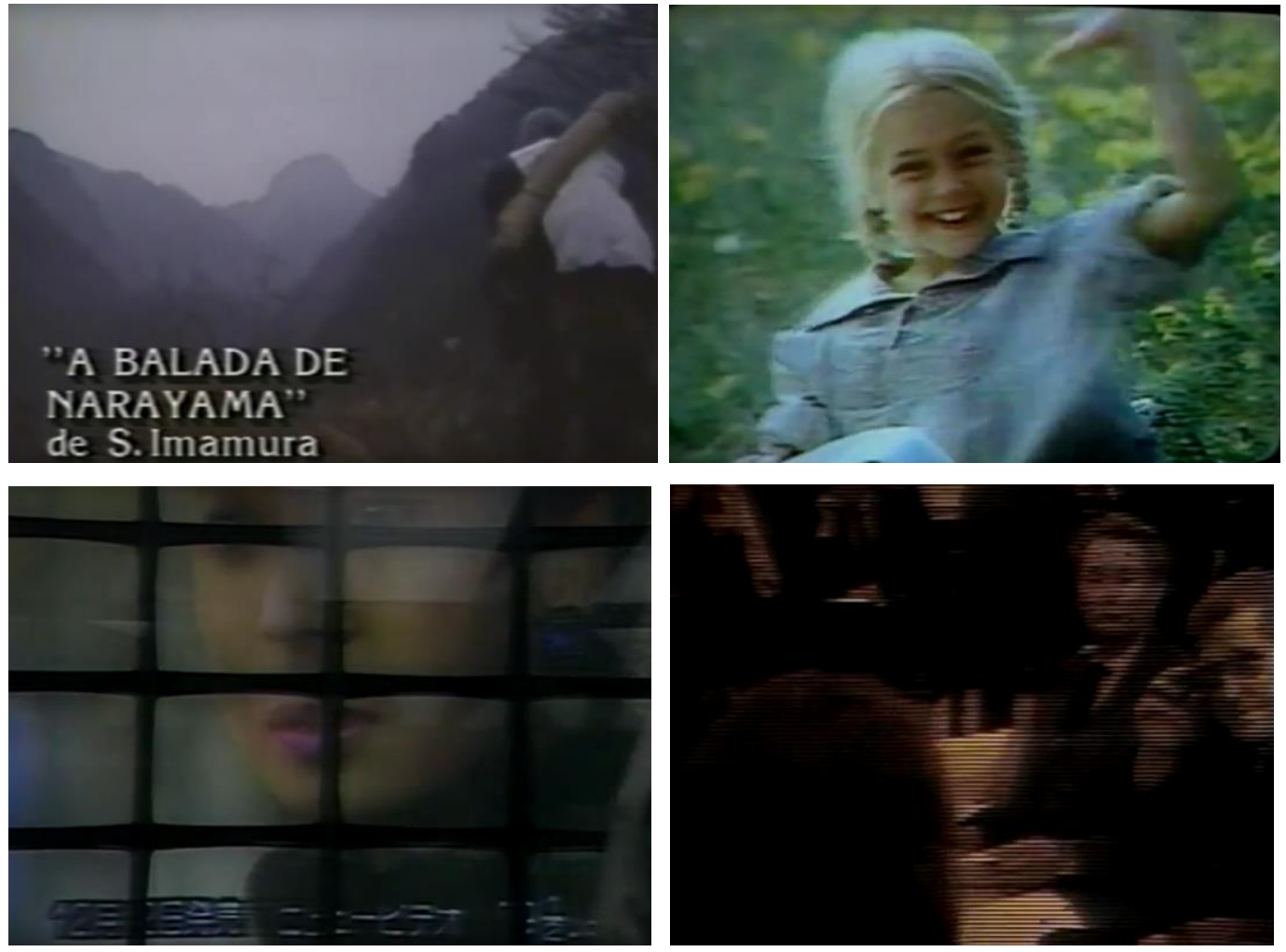

Fig. 40. Trânsito entre-imagens na série Japão: uma viagem no tempo.

Pois é exatamente esse "espaço multiplicável e heterogêneo" da imagem que atravessa todo o documentário. Imagem que não se resume apenas às mídias eletrônicas, pois, conforme sublinhado pela narração por mais de uma vez ao longo da série "No Japão, tudo é imagem", inclusive os grandes outdoors que se amontoam por Tóquio. Nesse sentido, a sequência sobre a sociedade patriarcal no terceiro episódio é bastante expressiva acerca do vídeo como um lugar atemporal de passagens.

\footnotetext{
${ }^{155}$ XAVIER, 2005, p. 196.

${ }^{156}$ DUBOIS, 2004, p.84.
} 
Começamos assistindo a múltiplas imagens televisivas que revelam a moda japonesa acompanhadas de uma trilha sonora eletrônica. $\mathrm{O}$ narrador, então, nos diz que no Japão as coisas mudaram, pois, se agora há uma moda feminina de vanguarda, aquela sociedade sempre foi uma das mais rígidas sociedades patriarcais do mundo. Em seguida, são exibidas algumas pinturas japonesas retratando a mulher no meio rural. Uma lenta fusão nos leva a Contos da Lua Vaga e o narrador analisa a submissão da mulher no filme de Kenji Mizoguchi. Em seguida, novas pinturas de mulheres confinadas atrás das grades de bordéis. Outra fusão nos apresenta um filme de Akira Korosawa (não identificado neste momento pela série), no qual vemos a mesma cena de gueixas atrás das grades. Mais uma fusão e surge a imagem de uma gueixa, agora no presente das filmagens, caminhando solitária pelas ruas de Kyoto. Um última fusão nos apresenta uma cena de sexo do filme Império dos Sentidos (1976, Nagisa Oshima), no qual a prostituta pervertia a sociedade japonesa ao sentir prazer. Por fim, uma panorâmica percorre as ruas do bairro Yoshiwara (Tóquio), repleto de banhos-turcos.

Essa longa sequência é expressiva da lógica do vídeo como um fluxo ininterrupto de imagens heterogêneas que se "libertam" de seus referentes e se cristalizam numa só. O próprio constante recurso à fusões, rechaçado em boa parte pelo cinema moderno, assinala a condensação de uma imagem na outra.
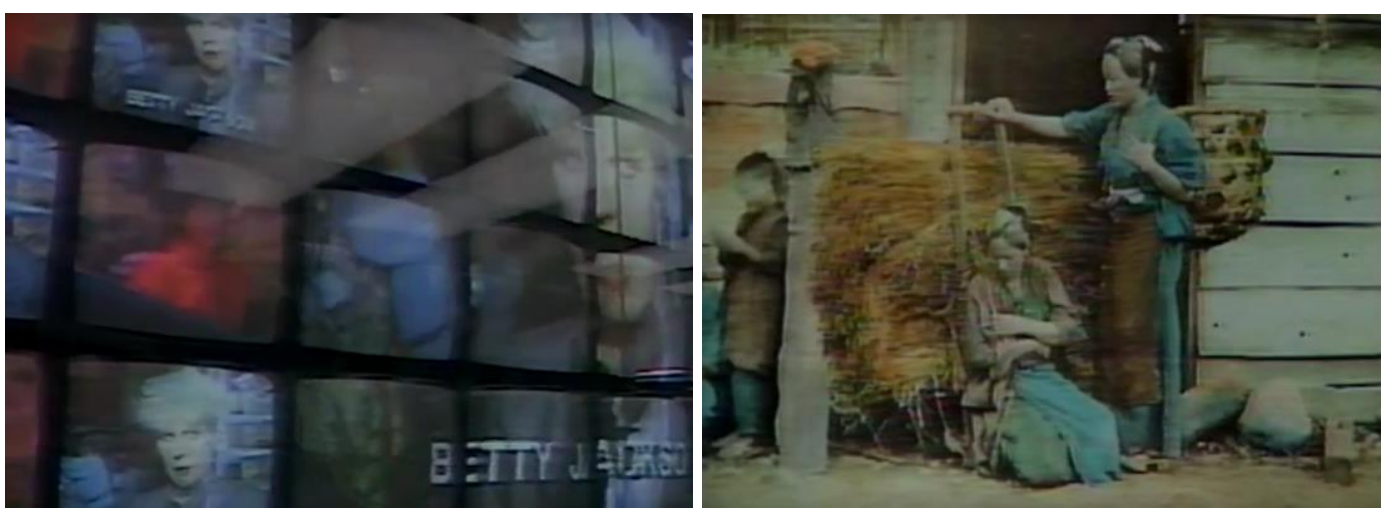

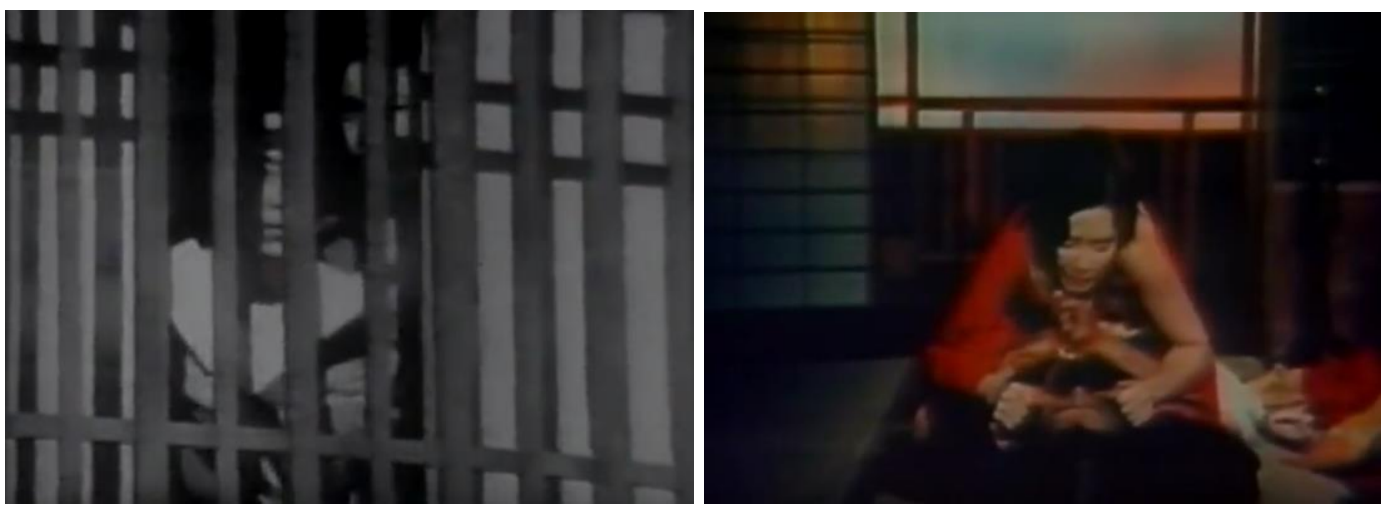

Fig.40. O fluxo de imagens heterogêneas na sequência sobre a sociedade patriarcal.

Entre a moda, a música e outros tantos aspectos culturais, a arquitetura parece sintetizar bem a profusão de imagens na sociedade japonesa. No episódio três, o narrador anuncia a obsolescência que marca o capitalismo contemporâneo: “[...] numa sociedade rápida, como a do Japão, o que é novo hoje, amanhã pode ser considerado velho". Logo, são exibidas imagens do Centro Cívico Tsukuba, um conjunto de prédios onde se misturam todos os estilos arquitetônicos possíveis, conformando uma estética pós-moderna. $\mathrm{O}$ arquiteto daquela obra, Arata Isozaki, a explica:

\begin{abstract}
Hoje em dia, é possível olhar as várias fontes de estilos como simples imagens num catálogo. Assim, põem-se, lado a lado, sem fazer qualquer comparação entre elas, imagens egípcias, gregas, indianas, chinesas ou japonesas. Com isso, vemos todos os estilos arquitetônicos como simples imagens, sem referí-las a qualquer eixo no tempo. Desse ponto de vista, todas as distâncias são iguais, mesmo quando se trata de tradições tão diferentes [...] Não há nenhuma distância que nos separe mais ou menos de nenhuma delas $[\ldots]$.
\end{abstract}

$\mathrm{O}$ argumento de Arata Isozaki conflui centralmente com a lógica que permeava a busca dessa geração de videastas. O fim das distâncias, o fim dos referentes e, por conseguinte, o fim das próprias temporalidades históricas no ideário de integração global. E, nesse sentido, o vídeo era o próprio caminho por onde todas as imagens possíveis (cinema, publicidade, fotografias, tvs, outdoors, etc.) confluíam sem nenhuma barreira, como num constante "catálogo", prontas para o consumo, pois esta é a única lógica que as preside. É no hibridismo do vídeo que se expressam, portanto, o hibridismo das identidades, das distâncias, das temporalidades, das tradições. 
No entanto, sem tomar o vídeo a partir de uma essência ou de forma fetichizada, é importante atentar que tanto a perspectiva da série quanto a própria construção de sua imagens possuem questões estéticas e políticas que foram problematizadas por outras linhas de raciocínio. Como introdução à questão recorro a Eduardo Coutinho, que nos apresenta criticamente a dissonância geracional a partir de um certo fascínio pela tecnologia per si:

Tornou-se um truísmo, no Brasil, dizer que o cinema é um meio arcaico e o vídeo, o equipamento eletrônico, representa o progresso, o contemporâneo. O que vi no Globo Repórter mostra o perigo de análises puramente tecnológicas, sem levar em conta os condicionamentos sociais e políticos. [...] nessa época, apesar da ditadura, nosso núcleo constituía-se num nicho dentro da emissora, onde se permitia um trabalho mais autônomo, mais lento, mais aberto à controvérsia e a uma relativa experimentação. Em 1982, o programa entrou na era eletrônica. De um golpe, o controle se tornou mais fácil e estrito [...] Em pouco tempo, o documentário transformou-se em reportagem [...] tornou-se asséptico, integrado, neutralizado [...] lógica da homogeneização e da rentabilidade a qualquer preço $^{157}$.

Essa argumentação de Eduardo Coutinho novamente retoma os postulados de Jean-Louis Comolli sobre um sentido documental contrário à lógica roteirizada e "limpa" das ficções. Pois é precisamente um documentário asséptico, em que o catálogo de imagens se presta exclusivamente ao consumo, que marca a série Japão: uma viagem no tempo. Ao contrário do trabalho desenvolvido, por exemplo, através do Globo Repórter, no documentário de Walter Salles não ocorre a confrontação com o real que marcou os documentaristas que migraram para a TV Globo nos anos 70. As entrevistas são tomadas sem qualquer problematização, as ambiguidades do real não se inscrevem na cena documental e, por vezes, presenciamos algumas asserções permeadas por fetichismo, como no trecho em que José Wilker nos diz que os bêbados japoneses são bemcomportados.

O que prevalece em Japão: uma viagem no tempo é um constante fascínio e exibição de imagens da massificada cultura nipônica. Não à toa é a teoria do pósmoderno que o filme convoca para o diálogo. Fredric Jameson assinala o pósmodernismo como a expressão cultural do capitalismo tardio, fase em que o

${ }^{157}$ COUTINHO, 2015, p. 227. 
sistema requer uma sociedade de imagens voltadas centralmente para o consumo $^{158}$. Resumidamente, com a reestruturação produtiva ocorrida a partir dos anos 60, instituiu-se gradativamente um padrão de acumulação flexível, o que, por um lado, gerou altas taxas de desemprego estrutural, e, por outro, ampliou expressivamente o setor de serviços e acelerou o ritmo de consumo, dado que a flexibilidade na produção pressupunha uma maior constância na inovação de mercadorias. Conformava-se, assim, a obsolescência do mundo contemporâneo sinalizada na série de Walter Salles, e o tempo passou a ser experimentado de modo cada vez mais fugidio e presentificado pela lógica do mercado. Segundo Jameson, uma das principais características do pós-modernismo é a fusão entre cultura e economia, não havendo mais uma diferenciação explícita entre esses campos. Enquanto o modernismo buscava afirmar a autonomia da cultura como espaço de experiência autêntica em contraposicão à esfera da mercadoria, no pósmodernismo a própria cultura se tornou um produto vendável como qualquer outro. Visão similar é compartilhada por David Harvey:

\begin{abstract}
A estética relativamente estável do modernismo fordista cedeu lugar a todo fermento, instabilidade e qualidades fugidias de uma estética pós-moderna que celebra a diferença, a efemeridade, o espetáculo, a moda e a mercadificação de formas culturais ${ }^{159}$.
\end{abstract}

Embora não se trate, aqui, de fazer uma sistematização sobre a estética pósmoderna, é importante ressaltar que essa nova lógica cultural retoma diversos traços do modernismo sem a sua dimensão utópica. David Harvey assinala, por exemplo, que a colagem e a montagem, tão caras ao pensamento de Walter Benjamin, são também pilares do pós-modernismo, porém sem qualquer pretensão holística e de conexão crítica entre as temporalidades históricas. Postulava-se, assim, uma constante desconstrução, em que a experiência era reduzida a "uma série de presentes puros e não relacionados no tempo"160, gesto diametralmente oposto à concepção de um "presente impuro que ao ser registrado

\footnotetext{
158 JAMESON, 2007.

${ }^{159}$ HARVEY, 1993, p. 148.

160 Ibidem, p. 57.
} 
pela câmera revela o trabalho do tempo e a coexistência dos fluxos da vida naquele momento", postulado por Serge Daney ${ }^{161}$.

Como argumentam Harvey e Jameson, a ausência de possibilidade de tratamento do tempo de forma dialética, "impuro", resulta em adesões consternadas ou pragmáticas ao status quo, isto é, à sociedade capitalista fundada na proliferação de imagens publicitárias, sem memória. Precisamente sobre o vídeo, Jameson percebe no fluxo ininterrupto de imagens um elemento dificultador sobre o trabalho de distanciamento crítico do espectador e, por conseguinte, da relação com a própria memória, reforçando a ideia de eterno presente que marca a distopia pós-moderna. A perda da historicidade, como já havia sinalizado Walter Benjamin, consiste no próprio esfacelamento de projetos futuros.

Não obstante, parece-me importante não essencializar um aparato tecnológico, mas inscrevê-lo social e historicamente. Assim como Raymond Bellour, Philipe Dubois vislumbrava no vídeo a possibilidade de modificar a percepção espaçotempo do espectador em relação às imagens, seja pelo seu congelamento, seja pela mudança de velocidade, seja pelas constantes passagens. Em outras palavras, "tomar nosso tempo diante da imagem" ${ }^{162}$. Na série Japão: uma viagem no tempo, essas possibilidades estão diluídas em uma lógica expositiva que organiza as imagens como uma série de trechos de um catálogo a serem desfrutados pelo espectador. Afasta-se a experimentação do espaço-tempo em prevalência do consumo publicitário, o que foi sinalizado por alguns autores como uma estética "clean"163. A noção de superficie se revela central para compreender como as imagens se dispõem nessa lógica. Brandon Taylor assinala a televisão como:

[...] o primeiro meio cultural de toda a história a apresentar as realizações artísticas do passado como uma colagem coesa de fenômenos equi-importantes e de existência simultânea, bastante divorciados da geografia e da história material [...] num fluxo mais ou menos ininterrupto ${ }^{164}$.

\footnotetext{
${ }^{161}$ FRANÇA; LINS; GERVAISEAU, 1999.

${ }^{162}$ XAVIER, 2005, p.197.

${ }^{163}$ BENTES, 2007.

${ }^{164}$ TAYLOR apud HARVEY, 1993, p. 63.
} 
Sendo assim, o espectador compartilha "a própria percepção da história do meio como uma reserva interminável de eventos iguais" ${ }^{165}$. Nesse sentido, Harvey aponta uma mudança da relação do artista com a história, prevalecendo, na contemporaneidade, as superfícies em relação às raízes, as imagens citadas superpostas ao invés das superfícies trabalhadas ${ }^{166}$. No contexto dos anos 80 , em que a ideologia do fim das barreiras geográficas e dos referenciais históricos imperava, constata-se em Japão: uma viagem no tempo a articulação de "imagens em superfície", em que o tradicional e o moderno são exibidos e citados sem duração, elemento fundamental, segundo Comolli, para revelar a transformação e, por conseguinte, o adensamento crítico dos tempos. Na ausência de qualquer historicidade que o Centro Cívico Tsukuba tão bem expressava, os mais variados registros conformam uma sucessão de imagens sem passado e sem devir, como uma grande citação de imagens saturadas no presente.

Serge Daney descreve esse regime de imagens como uma terceira grande fase do cinema. Ao contrário da primeira, pautada pela profundidade e pela transcendência, e também da segunda, que se voltava através da opacidade contra o ilusionismo narrativo, na terceira fase "a falta de profundidade e a espe(ta)cularização de tudo são a regra"167. É, portanto, nesse casamento entre o espetáculo e a ausência de historicidade que percebo a série Japão: uma viagem no tempo, dado que se afastar da questão-Brasil, de forma genérica, pressupôs também se afastar de toda a experimentação da linguagem documental aqui desenvolvida com bastante vigor no corpo-a-corpo com o real. Eduardo Coutinho assinala, de forma bem precisa, a distância do seu fazer documental em relação às imagens de Japão: uma viagem no tempo:

Às vezes, a televisão exibe documentários. [...[ Fala-se em olhar, que supõe escuta. Todos os documentários estrangeiros feitos no Brasil, a despeito das melhores intenções, acabam reproduzindo os estereótipos do etnocentrismo ou, de qualquer forma, passando longe do real. Como pode alguém dialogar com um interlocutor do qual não domina a língua? [...] Nesse universo, o que não conhece a língua só pode sobrevier se, ao invés de contornar esses problemas, tematizá-los e fizer da

\footnotetext{
165 Ibidem.

${ }^{166}$ HARVEY, 1993, p. 63.

${ }^{167}$ DANEY, 2007, p. 232.
} 
diferença um trunfo, da estranheza um método de conhecimento. O resto é folclore ${ }^{168}$.

Fica patente, portanto, que nem o aparatos nem a gerações subsequentes, em si, constituem formais mais "modernas" ou complexas de manifestação da linguagem. Como procurei analisar ao longo deste trabalho, é na dialética de temporalidades, nas diferenças, que se encontram os pontos de análise mais críticos. As imagens da série Japão: uma viagem no tempo expressavam o divórcio não apenas com o Brasil, mas centralmente com ideias como emancipação, profundidade, gesto característico de fins dos anos 80, com a queda do Muro de Berlim e o triunfo do neoliberalismo. É nesse quadro que a utopia moderna das gerações anteriores, pelas mais variadas colorações que pudessem ter, cedia espaço à distopia pós-moderna através de imagens efêmeras e resignadas.

${ }^{168}$ COUTINHO, 2015, p. 229. 


\section{Conclusão}

A escrita deste trabalho consistiu em um verdadeiro desafio. Vindo do campo da História, minha principal busca foi abandonar os filmes como mera representação de algo e trabalhá-los em sua interioridade. Claro que a dimensão mais abrangente do processo histórico está presente, mas procurei, centralmente, investigar aspectos formais de cada filme e como estes expressavam determinados significados. Sendo assim, esta dissertação pode ser vista como um "rito de passagem". Termino a escrita certo de que a minha mirada sobre o cinema, principalmente o documentário, passa agora por outros caminhos que "o que o filme quis dizer". Afinal, o como ele quis dizer é muito mais revelador, inclusive, do próprio processo histórico que não abandonei, ainda que o tenha posto em segundo plano.

Nesse percurso, as leituras de Jean-Louis Comolli foram imprescindíveis para perceber como a imagem documental pode interferir nas batalhas midiáticas escapando ao mundo roteirizado, valorizando o residual, as parcelas de realidade/humanidade que nenhuma imagem voltada para o consumo/espetáculo possui a capacidade de exibir de modo íntegro. Foram, também, fundamentais para compreender o gesto documental de não ter a pretensão de dar conta plenamente do real, mas da síntese que o filme gera ao confrontá-lo.

Como as questões nacionais foram tratadas e modificadas ao longo de cada filme dos três primeiros capítulos revela um gradual desgaste, no documentário nacional, dos discursos de sobriedade. Se a tendência a ficarem restritos a filmes com caráter mais panfletário de alguma organização política ou movimento social já era observada nos anos 80 , atualmente esse quadro se consolidou de vez. No amplo e rico cenário do documentário brasileiro, ao invés da impressão de objetividade, prevalece constantemente a inovação, o tensionamento da linguagem, o risco do real. Esse caminho trilhado, certamente, deve-se em boa parte a Eduardo Coutinho, cineasta decisivo em não se furtar ao diálogo com o real, colocando-se em cena e fabulando o mundo para além do aparente. Não por acaso, Coutinho foi a baliza crítica que utilizei tanto acerca dos filmes do capítulo 1 quanto da série documental do capítulo 4.

No capítulo 1, como sinalizei, embora engajados numa prática política "progressista", apesar da conotação positivista da palavra, foram os filmes que 
mais aprisionaram o real em prol das causas que defendiam. Mais grave e, consequência direta disto, é o aprisionamento do outro, dos trabalhadoras e trabalhadores em busca de visibilidade de suas lutas. Hoje o quadro é outro. Segundo Jean-Claude Bernardet, filmes como Migrantes e Liberdade de Imprensa foram importantes como possibilidade de maior abertura para que a voz do outro se expressasse de forma mais íntegra. Contudo, ele ressaltava que essa voz só poderia vir à tona, efetivamente, quando os meios de produção também estivessem à disposição deles. Com a ampliação da educação e a democratização do acesso aos bens de consumo, inclusive a própria cultura num sentido mercadológico, que os anos de governo do PT trouxeram ao país, uma nova geração de cineastas oriundos da própria periferia (ex: Adirley Queirós, Affonso Uchoa), tem revolucionado a perspectiva da alteridade no cinema brasileiro. Abandona-se, assim, a lógica dos documentários do capítulo 1, onde o documentarista cedia a voz ou falava pelo outro, para um momento no qual eles próprios registram, montam e representam a sua voz. Claro que esse jogo é marcado por disputas políticas e ideológicas, e não necessariamente essa voz irá se expressar de forma emancipada. Porém, a entrada dessa nova geração é um fato revolucionário numa tradição sempre marcada pelas dissonâncias de classe na representação das contradições sociais.

Os capítulos 2 e 3, a seu modo particular, expressaram o já mencionado desgaste das representações fundadas numa enunciação exterior à cena fílmica. Nos documentários do capítulo 2, os diretores estão em cena ativamente provocando o espectador. Essa presença, inevitavelmente, faz com que quem os veja perceba o filme como um produtor de significados e, portanto, as suas proposições assertivas resultam como processo, e não como evidência. A síntese dialética dessa relação passa por todos, diretores, personagens, composição fílmica e espectadores. Essa parece ter sido a tradição que mais deixou legados às novas gerações que, através de procedimentos formais operados por esses filmes (encenação, reflexão, interação), têm produzido obras de grande valor na reabilitação das questões nacionais. Como exemplo, posso citar: Terra deu, Terra come (2010, Rodrigo Siqueira), misto de reencenação e registro das tradições culturais do país que sempre foram caras ao documentário nacional; Diário de uma busca (2010, Flavia Castro), no qual a ausência de vestígios do período ditatorial sugere a fabulação como forma de rememorar e, desse modo, de 
atualizar aqueles anos; A cidade é uma só (2011, Adirley Queirós), espécie de ficção documental contra as narrativas oficiais do progresso nacional.

Os filmes do capítulo 3, embora não tenham deixado um legado tão grande às imagens do presente, assinalam, nos anos 80, o completo desgaste do discurso de sobriedade no documentário nacional. A sua própria composição fílmica, a articulação do deboche, da ironia, a recepção da crítica como um "fato novo" a revigorar o documentário brasileiro sinalizam esses dois documentários como um grito a subverter por completo a tradição objetivista que havia se consolidado nas décadas anteriores. São, portanto, duas das respostas mais violentas àquela cinematografia do capítulo 1. E, embora não encerrem um sentido em seus enunciados, a sua potência reside justamente na proliferação de antíteses que incidem sobre as narrativas nacionais.

Já no capítulo 4, abordei uma geração mais recente que apontava o desgaste da própria "questão-Brasil" que permeou o moderno cinema brasileiro desde, pelo menos, a década de 50. A abertura política, uma maior integração com o mundo, a ideologia pós-moderna, a grande "Aldeia Global”, compunham o ideário daquela geração de novos realizadores que se lançaram a produzir séries documentais através do vídeo. Este, enquanto fluxo de passagens ininterruptas de todas as imagens, revelava-se a própria expressão, naquele momento, do hibridismo regional, temporal e identitário que se buscava. Entretanto, voltada a uma lógica imagética mercadológica, publicitária, a série Japão: uma viagem no tempo transmitia um real excessivamente clean e exótico, fetichizado. Nesse sentido, recuperando a metáfora do ser contemporâneo de Giorgio Agamben, um cineasta da primeira geração analisada neste trabalho, Eduardo Coutinho, revelava-se muito mais contemporâneo de seu tempo que os novos realizadores que se entregavam plenamente às luzes de sua época.

Tanto as formulações mais amplas de Bill Nichols sobre o campo documental quanto as análises particulares de Jean-Claude Bernardet sobre a voz do documentário foram de extrema relevância neste trabalho. Ambos colocam a questão do positivismo que eu já havia me deparado na História e procurava estabelecer a ponte com o campo mais complexo das imagens. Desse modo, através da compreensão dos discursos de sobriedade pude adentrar de forma mais precisa a estrutura de cada filme, suas articulações persuasivas e como a voz do outro era posta em cena. Seja na tessitura histórica seja na realização documental, 
o mesmo perigo as atravessa, o perigo do tempo "morto", acabado, plenamente reconstituído por quem as produz. É sempre no presente, enquanto síntese de temporalidades e disputas ideológicas, que $\mathrm{o}$ ato se dá de forma ativa e construtiva.

Por fim, conforme explicitado em alguns filmes recentes, cabe ressaltar que a "questão-Brasil" retornou nos últimos anos e segue sendo objeto de uma rica investigação estética no cenário do documentário brasileiro. É o próprio Brasil com todas as suas contradições históricas não resolvidas que surge em filmes tão diferentes como Doméstica (2012, Gabriel Mascaro), Martírio (2017, Vincent Carelli), O Processo (2018, Maria Augusta Ramos), entre tantos outros. No cenário de completa incerteza que vivemos com sucessivos golpes das classes dominantes, seja através do impeachment da presidenta eleita Dilma Rousseff, seja nas tantas contra-reformas como a trabalhista, seja no extermínio ininterrupto de indígenas, camponeses e negros favelados, o conjunto de filmes analisados neste trabalho consiste também em um riquíssimo acervo de imagens para investigar e refletir sobre nossa precária constituição nacional.

Se a década de 80 foi considerada "perdida" para uns, esse quadro não se aplica ao campo documental. Ainda que com muito menos realizações que atualmente ou nas décadas anteriores, este trabalho revelou uma imensa e rica profusão de imagens, assinalando um importante momento de viragem e transformação que as gerações seguintes vão assimilando e transcendendo. 


\section{Referências Bibliográficas}

AGAMBEN, Giorgio. A comunidade que vem. Lisboa: Editorial Presença, 1993.

ANDRADE, João Batista de. O povo fala: um cineasta na área de jornalismo da TV brasileira. São Paulo: Editora Senac, 2002.

BELLOUR, Raymond. Entre-imagens. Campinas: Papirus, 1997.

BENJAMIN, Walter. Magia e técnica, arte e política: ensaios sobre literatura e história da cultura. São Paulo: Brasiliense, 2012 (Obras Escolhidas, v.1).

BENTES, Ivana. Vídeo e cinema: rupturas, reações e hibridismo. In: MACHADO, Arlindo. Made in Brasil: três décadas do vídeo brasileiro. São Paulo: Iluminuras/Itaú Cultural, 2007.

BERNARDET, Jean-Claude. Brasil em Tempo de Cinema - Ensaio sobre o cinema brasileiro de 1958 a 1966. São Paulo: Cia das Letras, 2007.

Brasiliense, 1985.

Cineastas e imagens do povo. São Paulo, SP:

BOURDIEU, Pierre. A ilusão biográfica. In: Razões práticas: sobre a teoria da ação, p. 74-82. Campinas: Papirus Editora, 2007.

BRAUDEL. F. A longa duração. In: História e Ciências Sociais. Lisboa: Presença, p. 7-70, 1976.

CAETANO, Maria do Rosário. João Batista de Andrade: alguma solidão e muitas histórias. São Paulo: Imprensa Oficial, 2004.

COHEN, Renato. A performance como linguagem. São Paulo: Perspectiva, 1989.

COMOLLI, Jean-Louis. Os homens ordinários. A ficção documentária. In: $O$ comum e a experiência da linguagem. GUIMARÃES, C.; OTTE, G.; SEDLMAYER, S. (Orgs.). BH: UFMG, 2007.

Ver e Poder: a inocência perdida - cinema, televisão, ficção, documentário. Belo Horizonte: UFMG, 2008.

COUTINHO, Eduardo. O olhar no documentário. In: A verdade de cada um: Amir Labaki (org.) São Paulo: Cosac Naify, 2015.

DANEY, Serge, A rampa. São Paulo: Cosac Naify, 2007.

DA-RIN, Silvio. Espelho partido: tradição e transformação do documentário. Rio de Janeiro: Azougue Editorial, 2004.

DIDI-HUBERMAN, Georges. Pueblos expuestos, pueblos figurantes. Buenos Aires:

Manantial,

2014. 
DREIFFUS, René Armand. 1964: A conquista do Estado. Ação política, poder e golpe de classe. Petrópolis: Vozes, 1981.

DEBORD, Guy. A sociedade do espetáculo: Comentários sobre a sociedade do espetáculo. Rio de Janeiro: Contraponto, 1997.

ESCOREL, Eduardo. Adivinhadores de água. São Paulo: Cosac Naify, 2005.

FECHINE, Y. O vídeo como um projeto utópico de televisão, In: MACHADO, A (Org.). Made in Brasil: três décadas do vídeo brasileiro. São Paulo: Itaú Cultural, 2003.

FERNANDES, Florestan. A revolução burguesa no Brasil. São Paulo: Globo, 2005.

FRANÇA, Andréa, LINS, Consuelo e GERVAISEAU, Henri. Serge Daney: O cinema como abertura para o mundo. Cinemais, no 15, jan/fev de 1999.

Globo-Shell Especial e Globo Repórter: o documentário entre a efemeridade e a tomada de posição. In: GOMES, I. M (Org.). Análise de telejornalismo - Desafios Teórico-Metodológicos. Salvador: EDUFBA, 2012.

Jânio a 24 Quadros e a montagem como farsa. Devires, BELO HORIZONTE, V. 12, N. 2, P. 52-67, Jul/Dez 2015.

Séries documentais na televisão: o travelling-rasante de African Pop. Galaxia, São Paulo, n. 37, jan-abr., 2018, p. 80-93.

GAGNEBIN, Jeanne Marie. Apagar os rastros, recolher os restos. In: SEDLMAYER, Sabrina; GINZBURG, Jaime. (Org.). Walter Benjamin: rastro, aura e história. Belo Horizonte: Editora UFMG, 2012.

. “Esquecer o passado?". In: MACHADO, C.E.J; MACHADO JR., Rubens; VEDDA, Miguel (Org.). Walter Benjamin: experiência histórica e imagens dialéticas. São Paulo: Editora UNESP, 2015.

Limiar, aura e rememoração. Ensaios sobre Walter Benjamin. São Paulo: Editora 34, 2014.

GINZBURG, Carlo. Mitos, emblemas, sinais: morfologia. São Paulo: Companhia das Letras, 1989.

HARVEY, David. Condição Pós-moderna. São Paulo: Loyola, 1993.

JAMESON, Fredric. Pós-Modernismo: a lógica cultural do capitalismo tardio. São Paulo: Ática, 2007.

LE GOFF, Jacques. História e memória. Campinas, SP: Ed. UNICAMP, 1990.

LEMOS, Renato. Anistia e crise política no Brasil pós-1964. In: Topoi, Revista do Programa de Pós-Graduação em História Social da UFRJ, Rio de Janeiro, n.5, set. 2002. 
LINS, Consuelo. $O$ documentário de Eduardo Coutinho: televisão, cinema e vídeo. Rio de Janeiro: Jorge Zahar Editor, 2004.

MACHADO, Arlindo. Made in Brasil: três décadas do vídeo brasileiro. São Paulo: Iluminuras/Itaú Cultural, 2007.

MONTES, Maria Lucia. As figuras do sagrado: entre o público e o privado. In: NOVAIS, Fernando A. (Coordenador da coleção); SCHWARCZ, Lilia Moritz (Organizadora do volume). História da Vida Privada no Brasil: contrastes da intimidade contemporânea. São Paulo: Companhia das Letras, 1998.

NAGIB, Lucia. A utopia no cinema brasileiro. São Paulo, SP: Cosac Naify, 2006.

NICHOLS, Bill. A Voz do Documentário. In: Teoria Contemporânea do Cinema. RAMOS, Fernão Pessoa. (org.); (Volume II). São Paulo: Editora Senac, 2005a. . Introdução ao documentário. Campinas, SP: Papirus, $2005 \mathrm{~b}$.

La representación de la realidad: Cuestiones y conceptos sobre el documental. Barcelona: Ediciones Paidós, 1997.

OHATA, Milton (org). Eduardo Coutinho. São Paulo: Cosac Naify, 2013.

POLLAK, Michael. Memória, esquecimento, silêncio. Estudos Históricos, Rio de Janeiro, v. 2, n. 3, 1989.

RAMOS, Fernão. Cinema Verdade no Brasil. In: Documentário no Brasil: tradição e transformação. TEIXEIRA, Francisco Elinaldo (org). São Paulo: Summus Editorial, 2004.

O que é documentário?. In: Estudos de Cinema SOCINE 2000.

Ramos, Fernão Pessoa e Catani, Afrânio (orgs.). Porto Alegre, Editora Sulina, 2001, pp. 192/207.

RAMOS, José Mário Ortiz. Cinema, televisão e publicidade: cultura popular de massa no Brasil dos anos 1970-1980. São Paulo: Annablume, 2004.

RICOEUR, Paul. A memória, a história, o esquecimento. SP: Editora da Unicamp, 2007.

RIDENTI, Marcelo. Artistas e intelectuais no Brasil pós-1960. In: Tempo Social Revista de Sociologia da USP. São Paulo, v. 17, n. 1, p. 81-110, 2005.

ROCHA, Glauber. Origens de um cinema novo. Revisão crítica do cinema brasileiro. São Paulo: Cosac Naify, 2003.

RUBY, Jay. The Image Mirrored: Reflexivity and the Documentary Film. Journal of the University Film Association, Vol. 29, No. 4, THE DOCUMENTARY

IMPULSE: CURRENT ISSUES (Fall 1977), p. 3-11.

SACRAMENTO, Igor. Depois da revolução, a televisão: Cineastas de esquerda 
no jornalismo televisivo dos anos 70. 2008. 330 f. Tese (Doutorado em Comunicação) - Escola de Comunicação da Universidade Federal do Rio de Janeiro.

SALLES GOMES, Paulo. Cinema: trajetória no subdesenvolvimento. São Paulo: Paz e Terra, 1996.

SCHWARZ, Roberto. Cultura e política, 1964-69. In: O pai de família e outros estudos, p. 61-92. Rio de Janeiro: Paz e Terra, 1978.

STAM, Robert. Introdução à teoria do cinema. Campinas: Papirus, 2006.

VIEIRA, João Luiz. Câmera-faca - O cinema de Sérgio Bianchi. Santa Maria da Feira: Festival de Cinema Luso-brasileiro de Santa Maria da Feira, 2004.

WILLIAMS, Raymond. Marxismo e literatura. Rio de Janeiro: Jorge Zahar Editor, 1979.

XAVIER, Ismail. Alegorias do subdesenvolvimento: Cinema novo, tropicalismo, cinema marginal. São Paulo: Cosac Naify, 2008.

. O discurso cinematográfico: a opacidade e a transparência,

São Paulo: Paz e Terra, 2005.

\section{Textos publicados em periódicos}

AVELLAR, José Carlos. “'Mato eles?' e 'Chapeleiros' - a arte de fazer perguntas". Jornal do Brasil, 06/12/1983.

ESTADO DE MINAS. "Tancredo Neves em filme", Estado de Minas, 04/06/1985.

FERREIRA, Jairo. "Documentário na trilha da chanchada". Filme Cultura, n. 41, 1983.

FILME CULTURA. "A hora da reflexão": Entrevista com Renato Tapajós, Filme Cultura, 1986.

2013.

."E agora, Lúcia?", Filme Cultura, 60, julho/agosto/setembro

FOLHA DE SÃO PAULO. "Jânio, a revolução russa e a imprensa em três

filmes”, Folha de São Paulo, 01/09/1982.

. "Walter Salles Jr. começa a filmar 'A Grande Arte'

em novembro", Folha de São Paulo, 23/09/1988.

JORNAL O GLOBO. "Jânio a 24 Quadros vê com câmera irreverente a década de 60”, Jornal O Globo, 06/08/1982. 
MILLARCH, Aramis. "Terra para Rose, o documentário do ano". O Estado do Paraná, 25/10/1987.

ZERO HORA. "João Batista e o episódio de Tancredo". Zero Hora, Porto Alegre, $29 / 051985$.

\section{Filmografia}

CABRA MARCADO PARA MORRER. Direção: Eduardo Coutinho. 1984 (119 $\min )$.

CÉU ABERTO. Direção: João Batista de Andrade. 1985 (78 min).

JÂNIO A 24 QUADROS. Direção: Luiz Alberto Pereira. 1981 (85 min).

JAPÃO: UMA VIAGEM NO TEMPO (série de 4 episódios). Direção: Walter Salles. 1986 (120 min).

LINHA DE MONTAGEM. Direção: Renato Tapajós. 1981 (90 min).

MATO ELES?. Direção: Sérgio Bianchi. 1983 (33 min).

QUE BOM TE VER VIVA. Direção: Lúcia Murat. 1989 (100 min).

TERRA PARA ROSE. Direção: Tetê Moraes. 1987 (83 min). 